\title{
Panama: Selected Issues
}




\section{INTERNATIONAL MONETARY FUND}

IMF Country Report No. 17/106

\section{PANAMA}

\section{SELECTED ISSUES}

May 2017

This paper on Panama was prepared by a staff team of the International Monetary Fund as background documentation for the periodic consultation with the member country. It is based on the information available at the time it was completed on April 17, 2017.

Copies of this report are available to the public from

International Monetary Fund • Publication Services

PO Box 92780 - Washington, D.C. 20090

Telephone: (202) 623-7430 • Fax: (202) 623-7201

E-mail: publications@imf.org Web: http://www.imf.org

Price: $\$ 18.00$ per printed copy

\section{International Monetary Fund \\ Washington, D.C.}

(C) 2017 International Monetary Fund

CInternational Monetary Fund. Not for Redistribution 


\section{INTERNATIONAL MONETARY FUND}

\section{PANAMA}

\section{SELECTED ISSUES}

April 17, 2017

\section{Approved By \\ Valerie Cerra}

Prepared By Kimberly Beaton, Metodij Hadzi-Vaskov and Jun Kusumoto

\section{CONTENTS}

PANAMA'S GROWTH PROSPECTS: DETERMINANTS AND SECTORAL

PERSPECTIVES

A. Determinants of Growth: How Does Panama Compare?___ $\underline{3}$

B. Investment as a Driver of Growth: Can High Investment be Sustained over the Medium-term?

C. Transforming Panama into a Global Logistics Hub: What can Panama Learn from Singapore?

D. Leveraging Connectivity to Strengthen Tourism $\underline{20}$

E. Conclusions $\underline{25}$

\section{TABLES}

1. Overview of Ongoing and Planned Investment Projects Planned and Ongoing LargeScale Investment Projects 11

2. Growth Accounting: Estimated Average Contribution to Growth $\underline{14}$

3. Singapore and Panama: Comparing Logistics-Relevant Features $\underline{15}$

SPILLOVERS FROM EXTERNAL EXPOSURES TO PANAMA $\underline{28}$

A. Panama's External Linkages__ $\underline{28}$

B. Spillovers from the U.S. and the Region___ $\underline{36}$

C. Conclusions $\underline{45}$

\section{FIGURES}

1. Panama's Trade Linkages $\underline{30}$

2. External Linkages of Panama's Regional Banking Center $\underline{35}$ 
3. Impact of External Factors on Sectoral Growth in Panama $\underline{41}$

4. Impact of U.S. Growth on Sectoral Growth in Panama

\section{TABLES}

1. Business Cycle Comovement of Panama with Other Economies $\underline{36}$

2. Regression Results: Impact of External Factors of Panama's Growth $\underline{39}$

3. Interest rate spillovers in Panama 44

4. Exchange Rate Developments and Export Performance $\underline{45}$

SAFEGUARDING FINANCIAL STABILITY IN PANAMA: A FRAMEWORK FOR SYSTEMIC RISK OVERSIGHT AND MACROPRUDENTIAL POLICY

A. Introduction 47

B. Structure of Panama's Financial System and its Oversight $\underline{47}$

C. Financial Sector Developments $\underline{50}$

D. A Framework for Systemic Risk Oversight and Macroprudential Policy in Panama:

Building on Panama's Existing Framework $\underline{51}$

E. Crisis Management Framework__

F. Conclusions $\underline{65}$

\section{FIGURES}

1 Panama: Financial Sector Oversight $\underline{50}$

2 Transmission Mechanism of Selected Sectoral Macroprudential Instruments $\underline{62}$

\section{TABLES}

1. Structure of Panama's Financial System $\underline{48}$

2. Overview of Panama's Regional Banking Center ___ $\underline{48}$

3. Signals Indicating the Need for Macroprudential Policy ___ $\underline{55}$ 


\section{PANAMA'S GROWTH PROSPECTS: DETERMINANTS AND SECTORAL PERSPECTIVES ${ }^{1}$}

The opening of the expanded Panama Canal marks a unique opportunity to reevaluate Panama's growth model. This paper reassesses Panama's business model founded on its ability to be an attractive destination for international financial, business, and transportation services. $A$ growth diagnostic exercise suggests that Panama is well-placed to maintain this business model, with improvements in the quality of education, a strengthening of governance, and reductions in bureaucracy important to further strengthen Panama's comparative advantage. Additional analysis suggests that investment will continue to support growth, while the logistics and tourism sectors hold promise to further build on Panama's comparative advantage.

\section{A. Determinants of Growth: How Does Panama Compare?}

Panama has had exceptional growth performance over recent decades. This section explores the determinants of Panama's growth to assess prospects for this growth to continue and identifies improving the quality of education, strengthening governance and reducing bureaucracy as the growth policy priorities for Panama to maintain its business model and further cement Panama's competitiveness.

\section{Recent Growth Performance}

1. Panama has had the highest growth in LAC over the past two decades. This has resulted in a significant increase in its per capita income, which has doubled since 2004, and strong convergence of its income per capita with advanced economies. Exceptionally strong growth also contributed to an improvement in social-economic conditions, with important declines in poverty and income inequality. More recently, growth has begun to slow from its exceptionally high rates, reaching 4.9 percent in 2016 . The moderation has been primarily associated with a slowdown of construction, including due to the completion of the expansion of the Panama Canal. In this context, the economy appears to have reached a turning point where the drivers of growth may be shifting from construction to services. While Section B suggests that investment will continue to be supportive of growth and Sections C and D consider two service sectors that hold potential to emerge as important pillars of the Panamanian economy, this section assesses the extent to which the overall policy framework and macroeconomic and financial conditions remain supportive of growth and to what extent policy can play a role in helping to smooth the ongoing transition of the Panamanian economy to services.

\footnotetext{
${ }^{1}$ Prepared by Kimberly Beaton and Metodij Hadzi-Vaskov.
} 

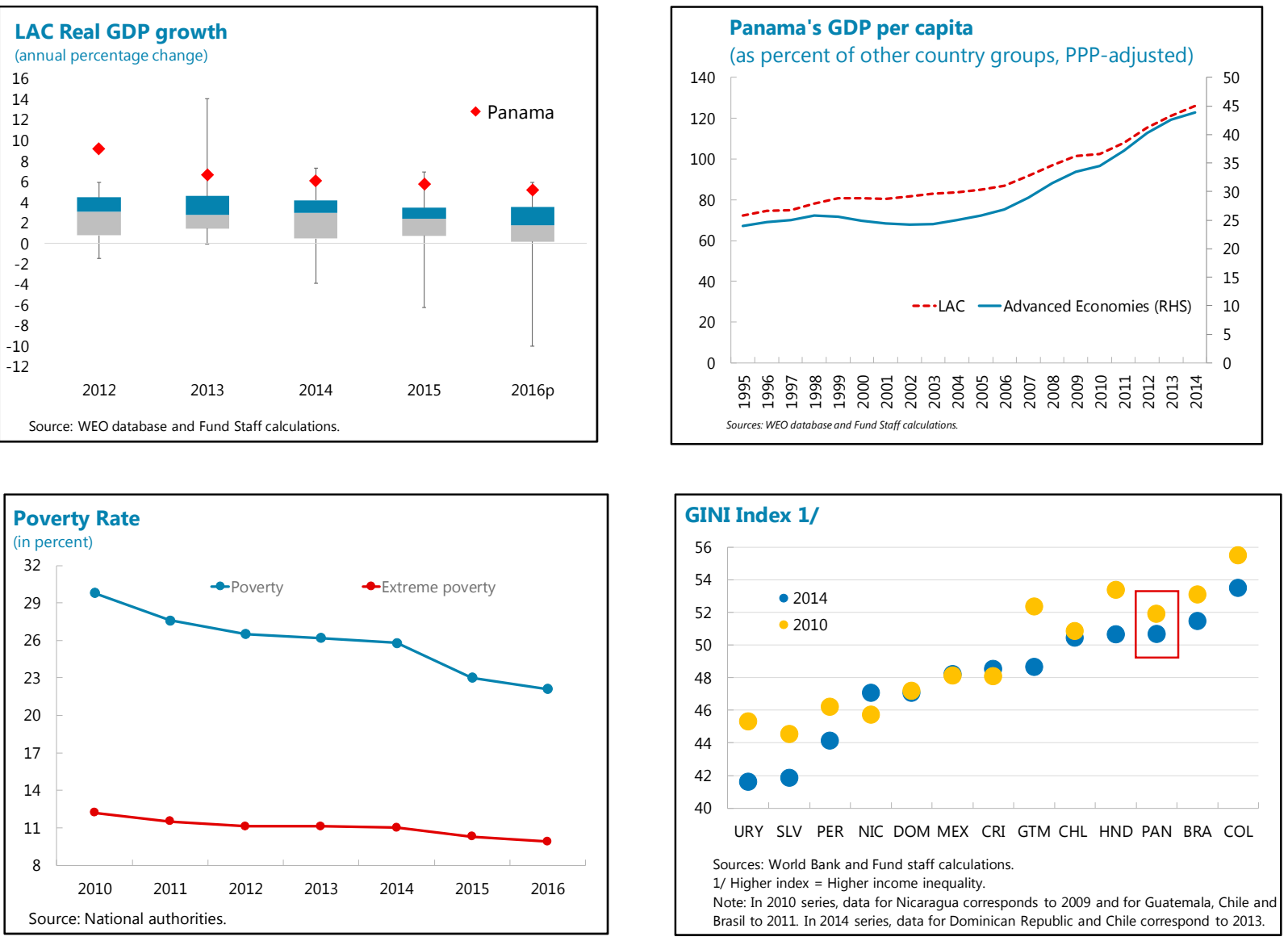

\section{Growth Determinants}

2. How can Panama improve its medium-term growth prospects? A precondition to designing effective growth policies is an understanding of an economy's binding constraints to growth. In this section, we assess Panama's relative performance in across a variety of growth determinants including infrastructure, education, access and cost of finance and the overall business environment. Based on this analysis, we identify the binding constraints to growth for Panama and recommend specific policies to strengthen medium-term growth prospects. 


\section{Infrastructure}

\section{Overall infrastructure quality is high in the regional context and supportive of}

investment. Panama ranks highly in overall infrastructure quality, according to the World Economic Forum, particularly compared to its peers in Latin America and the Caribbean (see Annex Figure I). The high overall ranking can be directly linked to Panama's role as a regional transportation hub: the quality of air transportation infrastructure benefits from Tocumen airport's role as a regional hub and, similarly, the quality of port infrastructure far exceeds other countries in Latin America due primarily to the Panama Canal. The quality of road transportation also ranks amongst the highest in Latin America. With the importance of the Panama Canal and related port and logistics activity, Panama is highly competitive in logistics with supportive infrastructure and related processes (e.g. customs) in place. Recent and ongoing infrastructure projects promise to further strengthen Panama's supportive infrastructure in these areas: the Panama Canal

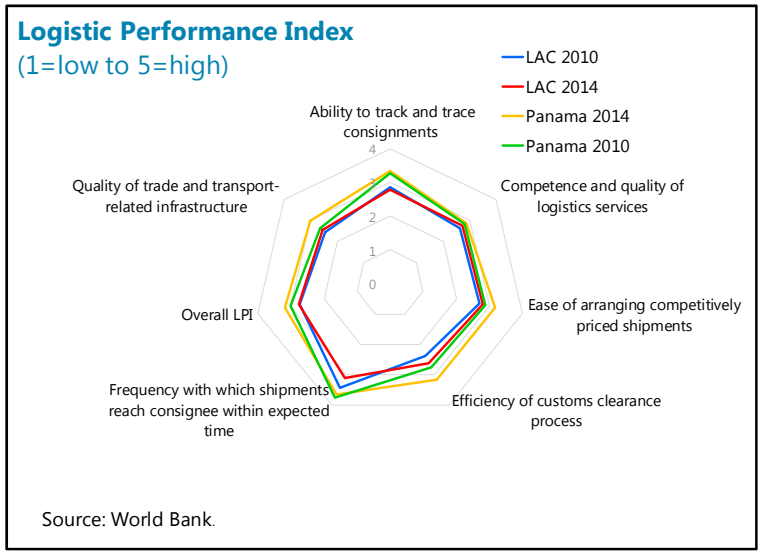
expansion began commercial operations in June 2016 and the extensive expansion of the Tocumen airport is expected to be completed in 2018.

\section{Energy and communications infrastructure are also supportive of growth. As with} transportation and logistics infrastructure, the quality of Panama's energy infrastructure compares favorably to other countries in Latin America, although its comparative advantage is not as striking as with the former. Panama is a net exporter of electricity, exporting electricity to Costa Rica. New transmission lines are in the process of being constructed (see Section B) that will enable Panama to increase its electricity exports, with potential to export to South America. With respect to communications infrastructure, Panama is a regional telecommunications hub as the Panama Canal is the interconnection point of several international fiber submarine cables. Despite this advantageous position, internet usage is low compared to other countries in Latin America. Hausmann, Espinoza, and Santos (2016) conjecture that this puzzle may be related to income inequalities and associated differences in the coverage of the internet grid across Panama, an explanation that bears credence. 


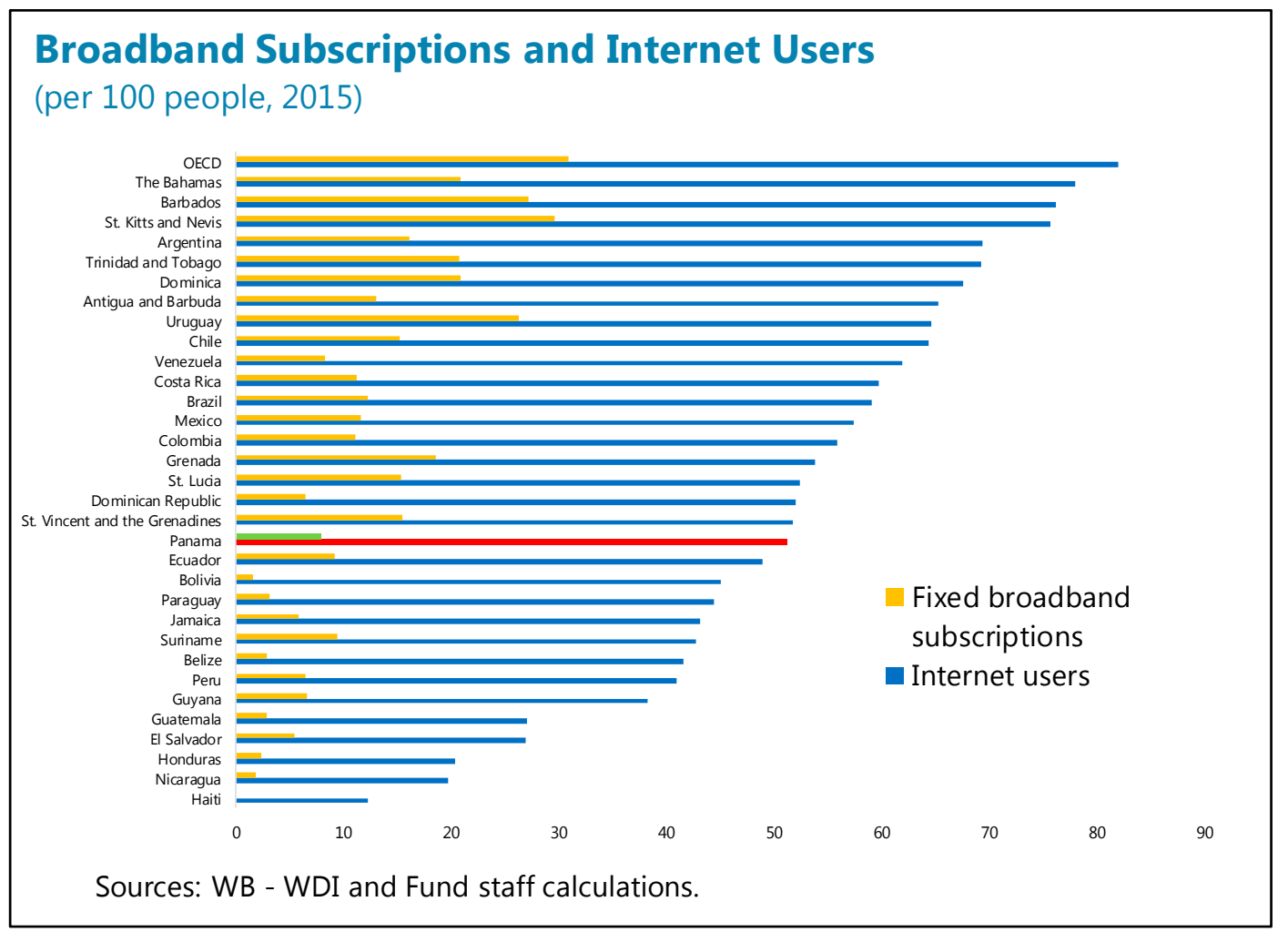

\section{Education}

\section{Strengthening the quality of education will be important to improve growth}

prospects. The Panamanian workforce has a higher level of educational attainment than other countries in Central America and the Dominican Republic, but this has not translated into improved educational outcomes. Panama has both a higher share of secondary/tertiary graduates and average years of schooling of its population than comparator countries. Yet, Panama has performed poorly in international competency tests. For example, its performance in the 2013 TERCE test that assessed competency of third and sixth graders in Latin America across a variety of subjects suggests that educational quality is below that of most countries in Latin America. ${ }^{2}$ Performance was particularly weak in mathematics and reading comprehension. More generally, Panama has underperformed the Latin American region on the education and training

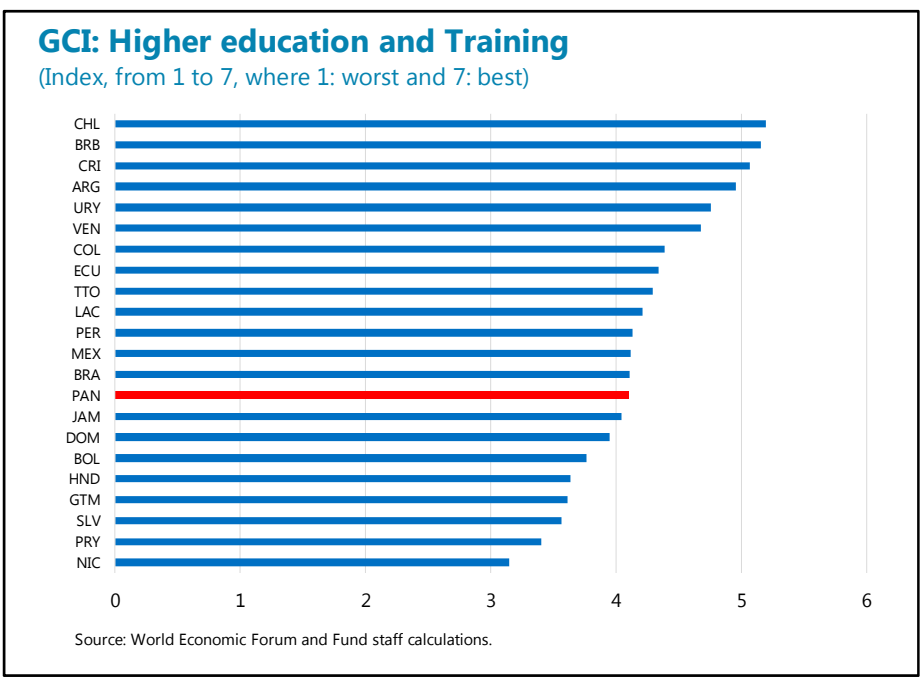

\footnotetext{
2 See also IMF Country Report No. 16/338.
} 
subindex of the World Economic Forum's Global Competitiveness Index and an inadequately educated workforce is the third most frequently cited problematic factor for doing business in Panama in its 2016-17 Global Competitiveness Report. Finally, there are indications that there may be a mismatch between the skills demanded by the Panamanian economy and those provided by the workforce, particularly as the economy continues its transition to a service-based economy increasing the demand for more skilled workers., ${ }^{3,4}$ In this regard, the government's renewed emphasis on education reform, including the new technical institute to address skills gaps will be key to moving up the value chain, especially in services.
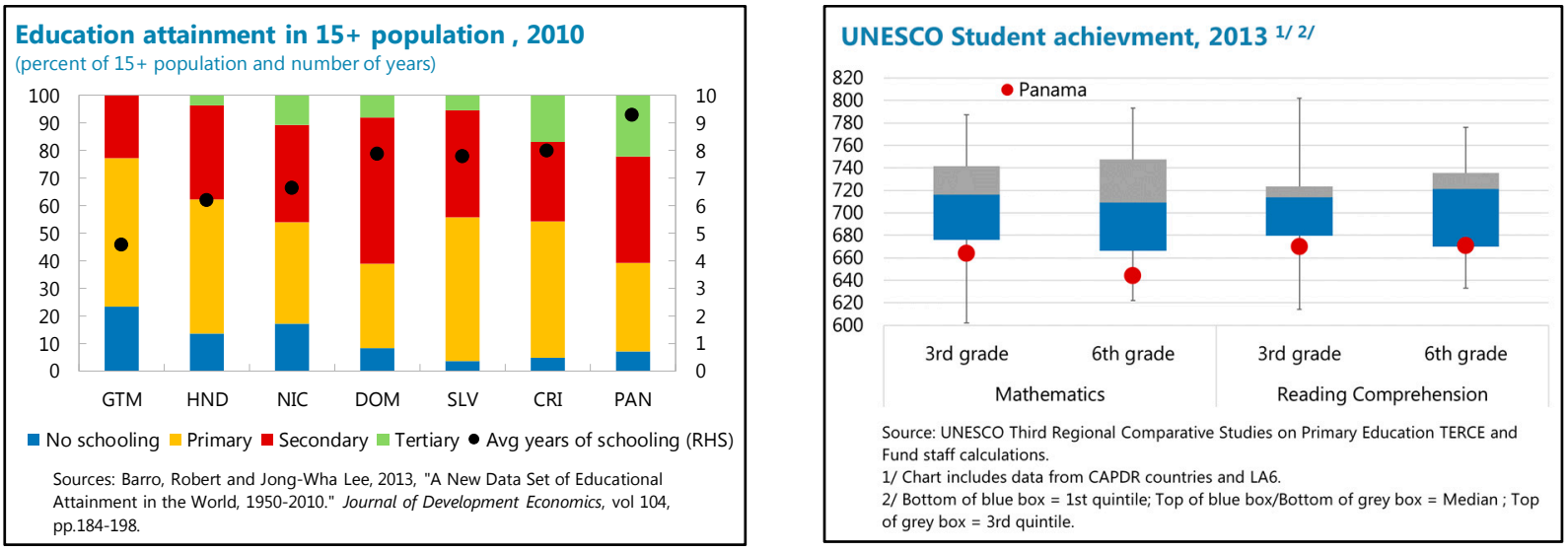

\section{Cost of Finance}

6. Panama is a regional financial center. Financial sector assets are sizeable at 238 percent of GDP. Banks dominate the system, representing about 90 percent of assets, with offshore banks holding about 16 percent of bank assets. ${ }^{5}$ The banking system is highly competitive with 55 banks serving the domestic economy, including two state-owned banks. Credit to the domestic private sector is high compared to regional standards and Panama's level of economic development. ${ }^{6}$ Panama also ranks highly, particularly compared to its Latin American peers, in terms of financial development and ease of access to credit. The highly competitive financial sector has also contributed to a low cost of finance, with the real lending rate amongst the lowest in Latin America.

\footnotetext{
3 See Hausmann, Espinoza and Santos (2016) for a more detailed analysis of the demand-supply imbalances in the Panamanian labor market.

${ }^{4}$ The Talent Shortage Survey 2016/2017 conducted by Manpower Group suggests that Panama especially lacks qualified technicians.

${ }^{5}$ Offshore banks are prohibited from conducting domestic banking operations and accept deposits and provide credit only outside of Panama.

${ }^{6}$ Despite strong credit growth, the credit gap is only modestly positive. However, Panama has experienced a prolonged credit boom since 2000, when credit data became available, suggesting that credit risks may be higher than suggested by the credit gap.
} 


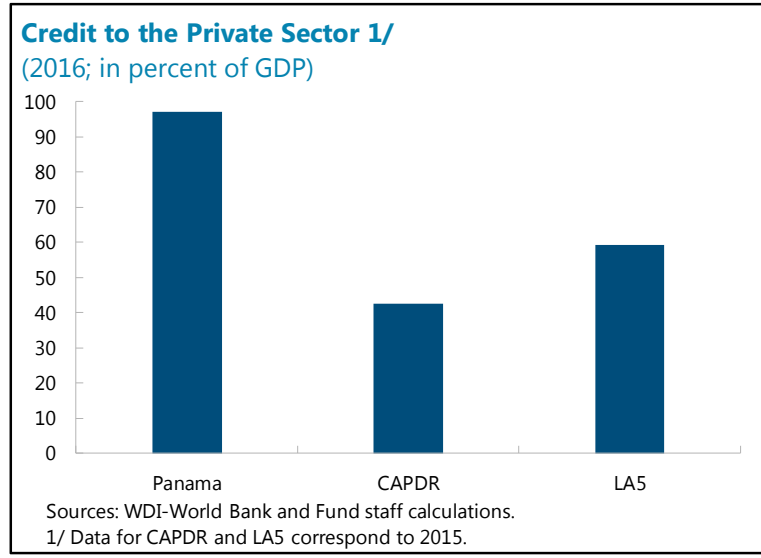

GCI: Financial market development subcomponents (Index, from 1 to 7, where 1: worst and 7: best)

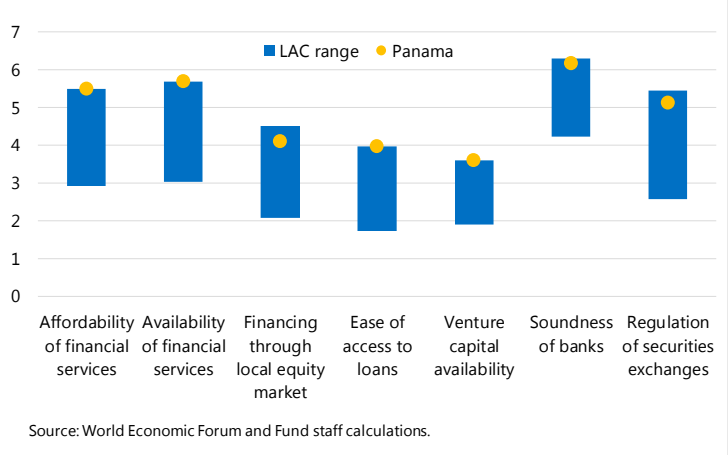

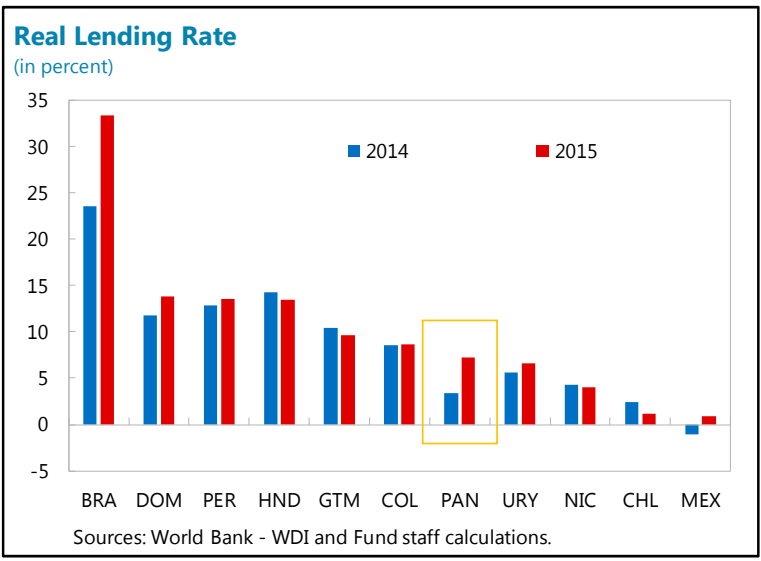

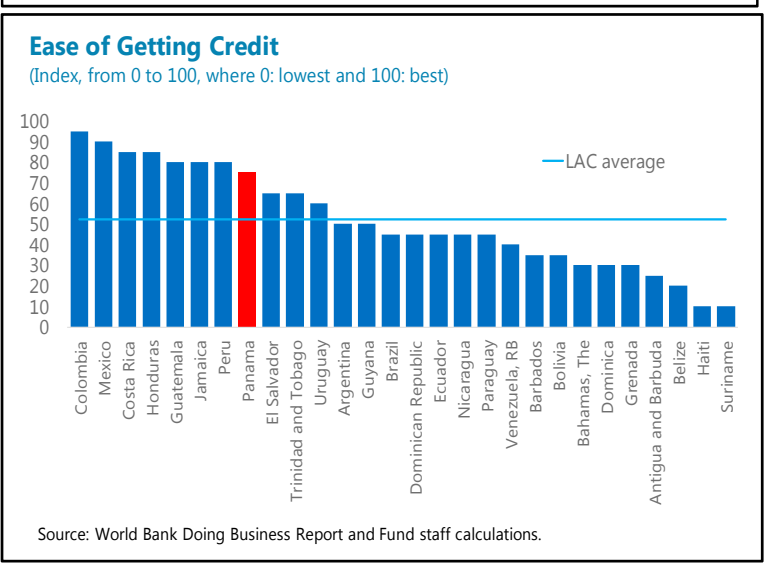

\section{Business Environment}

\section{Macroeconomic prospects benefit from Panama's macroeconomic policy framework,} anchored in fiscal discipline and financial sector stability. In addition to strong growth performance over recent years, the economy has benefited from price stability and low unemployment. Fiscal policy remains sustainable - rooted in the Social Fiscal Responsibility Law (SFRL), with public debt projected to remain below the SFRL target of 40 percent of GDP. The regional financial center has also been a source of stability, although macro-financial risks from the prolonged credit expansion remain a concern. In this context, a continued strengthening of financial sector oversight, particularly of systemic risks, will be important to safeguarding financial stability and ensuring that financial conditions remain supportive of growth. Development of a macroprudential policy framework and associated tools and a strengthening of the crisis management framework, including through a liquidity facility for banks, would be important complements (see Selected Issues Paper III). 


\section{At the microeconomic level, risks primarily relate to the need to strengthen}

governance and reduce bureaucracy. Typical risks tend to relate to tax regimes, labor market rigidities, and the general business environment including the extent of bureaucracy, crime and corruption. Tax rates and tax administration are unlikely to be a barrier to growth for Panama: Panama's tax-to-GDP ratio is amongst the lowest in Latin America and tax rates are generally lower than other countries in the region (both for direct and indirect taxes). Panama also performs well compared to other Latin American countries in labor market efficiency and a wide range of indicators with respect to the overall business environment including starting a business, obtaining construction permits, and registering property. Nevertheless, inefficient government bureaucracy is one of the identified most problematic factors for doing business in Panama and there is room for improvement. The key priority for reducing microeconomic risks will be to strengthen governance (text

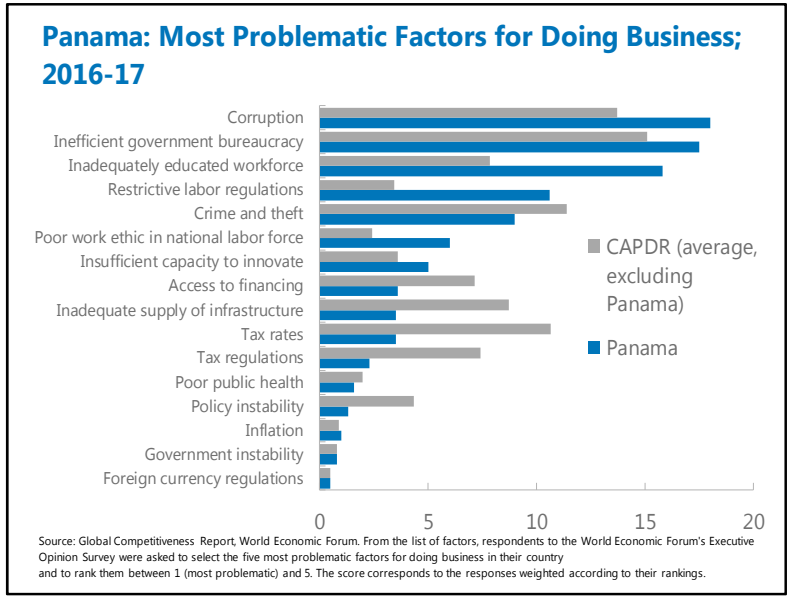
figure).
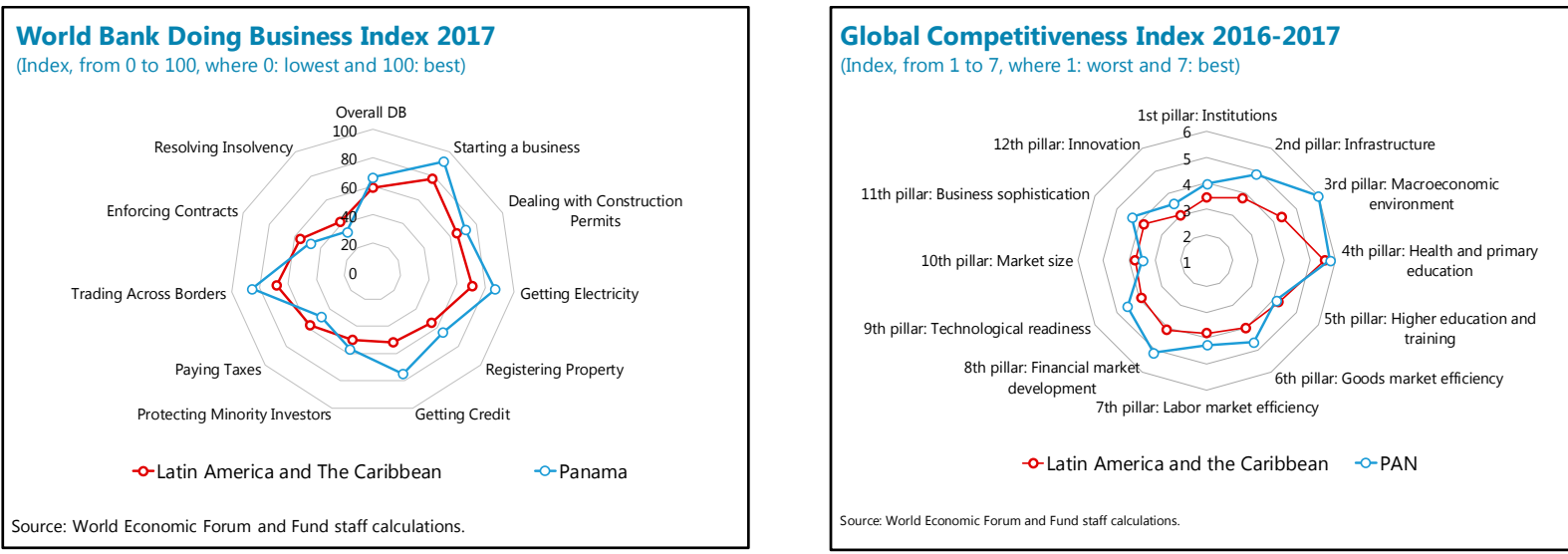

9. The growth diagnostic exercise confirms that Panama is well-placed to maintain its business model. The results of the diagnostic suggest that the most important challenge will be to advance reforms to the education system to ensure that the system is able to supply workers with the skills demanded in Panama's economy. In particular, addressing existing skills gaps will be key to moving up the value chain in services. Reducing bureaucracy and strengthening governance can also have important growth dividends. 


\section{B. Investment as a Driver of Growth: Can High Investment be Sustained over the Medium-term?}

Investment played a central role in Panama's successful growth story over the past decade. This section takes stock of investment's historical contribution to growth and assesses prospects to sustain investment-led growth. Based on the existing pipeline of public and private investment projects, estimates of their direct and indirect growth effects suggest that investment-led growth can be sustained, although at a more sustainable rate than in the recent past.

\section{Contribution to Growth from Large-scale Investment Projects}

\section{Large investment projects contributed strongly to Panama's exceptional growth in} recent years. Besides the expansion of the Panama Canal, the largest investment project (estimated at about US $\$ 5.3$ billion over 2007-16), several other large-scale projects were completed in recent years, including Metro line I, several highway sections, the Cinta Costera, and the urban renovation of Panama City's old town. Overall, investment (public and private) is estimated to have contributed on average 4 percentage points to Panama's annual economic growth over the period 2008-2016.

11. There is an extensive pipeline of ongoing and planned investment projects. Table 1 provides an overview of some of the largest projects under construction or in an advanced planning stage. Their total value is estimated at US\$16.7 billion, or about 30.3 percent of Panama's 2016 GDP. The largest private investment project Minera Panamá, with an estimated total value of US $\$ 5.5$ billion (with US\$2 billion remaining to be executed until its expected completion in 2018), surpasses the total investment value of the Panama Canal expansion.

\section{The wide range of investment projects can provide a significant boost to Panama's} medium-term economic activity. First, new investment will directly boost construction and other sectors of the economy. This effect increases with the inverse of the investment's import content. Second, investment projects affect the economy indirectly through multiplier effects across different sectors that follow the direct impact of construction activity. Third, new investment can increase the economy's productive capacity and strengthen its potential growth, particularly when projects address bottlenecks and improve efficiency. This analysis sheds light on all three aspects. 


\begin{tabular}{|ccc|}
\hline \multicolumn{3}{|c|}{$\begin{array}{c}\text { Table 1: Overview of Ongoing and Planned Investment Projects } \\
\text { Planned and Ongoing Large-Scale Investment Projects } 1 /\end{array}$} \\
\hline \multicolumn{1}{c|}{ Project } & Value & Status \\
\hline Public/government & 8.94 & \\
Metro line 2 & 2.10 & ongoing \\
Tocumen terminal expansion & 0.90 & ongoing \\
3rd High-voltage transmission line & 0.35 & ongoing \\
4rd High-voltage transmission line & 0.45 & planned \\
Urban renewal of Colon & 0.57 & ongoing \\
3rd bridge over the canal & 0.57 & ongoing \\
Metro line 3 & 2.60 & planned \\
4th bridge over the canal & 1.20 & planned \\
Technical Institute (ПSE) & 0.20 & ongoing \\
Private & 7.74 & \\
Minera Panama & 5.50 & ongoing \\
AES gas project & 1.15 & ongoing \\
Gas to Power Panama (Martano) & 0.90 & ongoing \\
Convention center Amador & 0.19 & ongoing \\
Total & 16.68 & \\
\% of 2016 GDP & 30.26 & \\
\hline Sources: News and Fund staff calculations. & & \\
1/ Not included: 4 key ACP projects and smaller highway sections. & \\
\hline
\end{tabular}

13. The estimated direct and indirect growth contributions from investment projects in the existing pipeline are sizeable. We quantify the direct and indirect effect of each investment project on growth. The direct effect is estimated by the project's contribution to domestic activity. ${ }^{7}$ In addition, we estimate the indirect (quantifiable) effect using approximations for public investment multipliers found in the empirical literature. The overall output multipliers are estimated based on the short- and long-term output elasticities to public capital in Bom and Ligthard (2014). ${ }^{8}$ Moreover, our analysis builds on Born and Ligthard (2014) by allowing for project-specific output multipliers to reflect the fact that all types of investment do not produce the same indirect effects across the economy. Specifically, we adjust the overall multipliers in Born and Ligthard (2014) based on the relative magnitude of multipliers for different types of investment projects estimated by Pereira and

\footnotetext{
${ }^{7}$ The import content of each project is estimated separately and goes from 30 percent in the case of the Colon renovation and the construction of the new technical institute (ITSE) to 70 percent in the case of the new Metro lines and the new gas power generation plants. Using this approach, the direct growth effect from the construction of ITSE, for instance, is estimated at US $\$ 137$ million, or about 0.24 percent of GDP.

${ }^{8}$ Bom and Ligthart (2014) present a survey of estimates found in 68 studies that aim to quantify output effects from public capital investment over the period 1983-2008. Our analysis uses the typical multiplier values presented by Bom and Ligthard (2014).
} 
Pereira (2015). ${ }^{9}$ The direct contribution to economic growth from investment projects identified in Table 1 is estimated at about 2 $1 / 2$ percentage points over 2017 and 2018 in the baseline scenario. In addition, the indirect contribution on economic growth through multiplier effects of these projects is estimated at $1 / 2$ percentage points on average over the period 2018-2021.

\section{The estimated contribution of} investment projects to economic growth is sensitive to the assumed timing of their completion and import content. To assess the sensitivity of the estimated growth effects to these assumptions, we consider an adverse scenario. The adverse scenario assumes three key differences with respect to the baseline: first, the import content of all investment projects is higher by 10 percentage points; second, the start of construction and the timeline for new projects is assumed to be shifted forward by one year; and third, the execution of ongoing projects is assumed to drop by $1 / 3$ in 2017 due to exogenous circumstances and project completion is correspondingly assumed to be delayed by one year. Such an adverse scenario is estimated to result in a lower growth contribution by about 1 percentage point per year.

\section{Infrastructure investments are likely to result in productivity enhancements and} strengthen potential growth prospects. In addition to the direct and indirect quantifiable effects, investment can improve the underlying functioning of the economy. For instance, the new metro lines can substantially shorten commuting time, lower street congestion, and generate additional commercial and construction activity by raising the attractiveness of remote areas because of improved connectivity. Energy investments in power generation can improve energy supply and potentially lower energy costs in production. Similarly, investments in new transmission lines can increase trading opportunities with neighbors, and thereby, improve efficiency of the electricity market and create extra revenues. In addition, the completion of the airport expansion can further strengthen Panama's attractiveness as an investment and tourism destination, and can offer

\footnotetext{
${ }^{9}$ Pereira and Pereira (2015) investigate the output elasticities of 12 different types of public infrastructure investments, such as railroads, ports, airports, health, education, and telecommunications for the case of Portugal. In our analysis, the largest multipliers are found for hospitals ( 0.16 in the following year), followed by telecommunications and energy infrastructure $(0.13)$, and road transportation $(0.07)$.
} 
synergies with other transportation modes to enhance the logistics sector (see Sections C and D). While a precise quantification of these gains is not straightforward, they are likely to be significant, as suggested by anecdotal evidence about recent projects. For example, Metro Line I shortened commuting time for many workers and helped generate commercial activity in some areas.

\section{Higher fiscal revenues are essential to support the financing of strategic public} investment projects. With the public sector accounting for over a half of the estimated value of the large-scale investment projects in Table

1 , a strong fiscal revenue base is needed to preserve space for planned investment. Nonetheless, despite a significant improvement registered in 2016, Panama's tax revenues remain among the lowest in the region and significantly below countries at similar levels of economic development. In this environment, recurrent spending may crowd out capital spending without further increases in tax revenues, thereby reducing growth contribution from

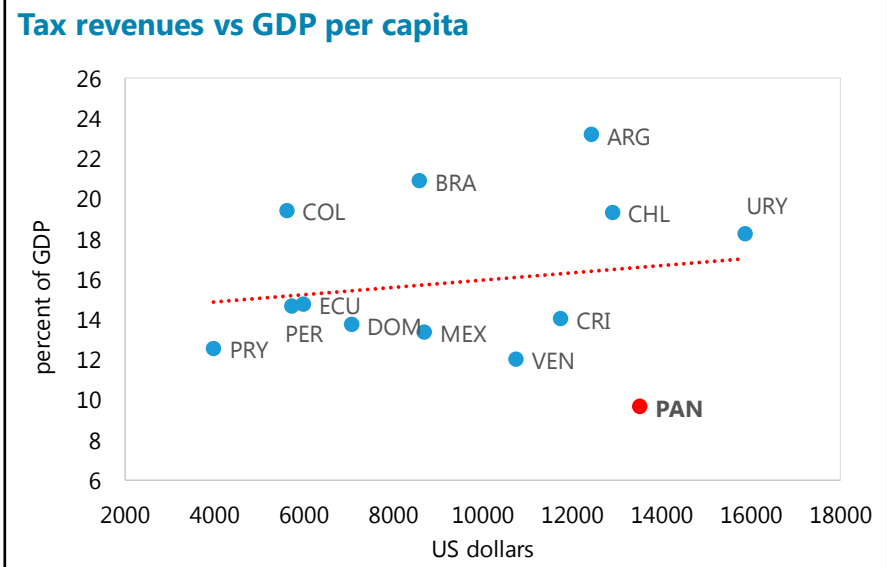

Source: WEO database and Fund staff calculations. investment.

\section{Growth Accounting and Factors of Production}

\section{Strong investment activity in recent years further boosted capital's dominance as a} contributor to growth among production factors. A simple growth accounting exercise suggests that capital accounted for over half of total growth over the period 2008-2015. ${ }^{10}$ This development reflects very strong private and public investment activity, which raised gross capital formation as a share of GDP from a trough of about 31 percent during the global financial crisis in 2009 to over 47 percent in 2014-5.

\footnotetext{
10 The growth accounting exercise assumed an initial capital stock that is three times larger than Panama's GDP, labor elasticity of 0.6 and capital elasticity of 0.4 , and a depreciation rate of 5 percent per year.
} 
18. Based on the existing pipeline of investment projects, capital is projected to remain a key contributor to growth, albeit at a more sustainable pace. Gross capital formation, estimated at about 47 percent of GDP in 2016, is projected to gradually decline to a more sustainable level of about 42 percent of GDP over the medium term. In turn, capital's average contribution to growth will be about 1 percentage point lower than over the period 2008-2015 and result in a slightly more moderate growth path. ${ }^{11}$ In this context, the projected slight moderation of investment to more sustainable levels is the key factor explaining the revision of projected medium-term growth from about 6 percent in the 2016 Article IV consultation to about 5.5 percent in the

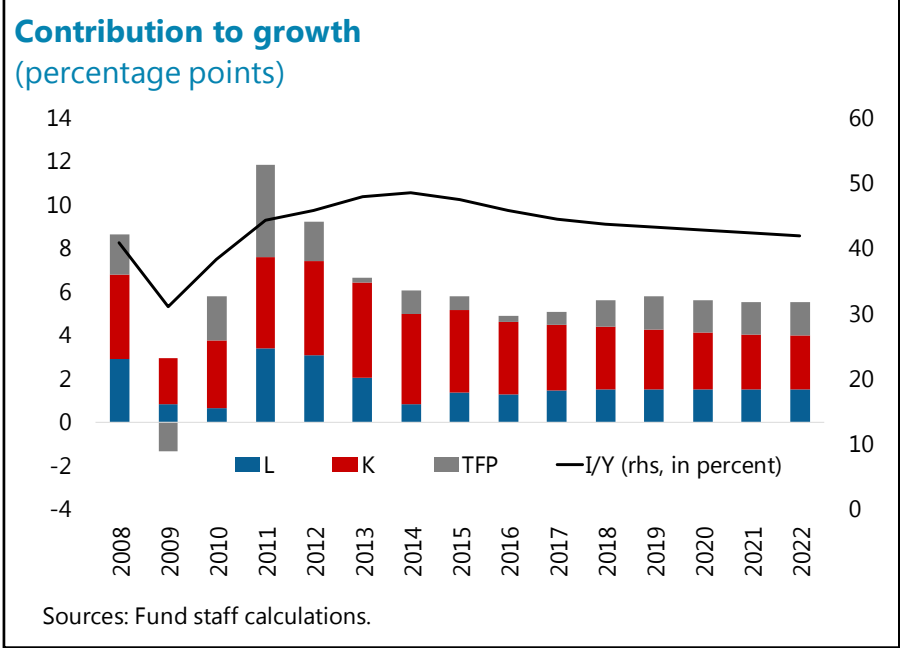
2017 consultation.

Table 2: Growth Accounting: Estimated Average Contribution to Growth

\begin{tabular}{|c|c|c|c|c|}
\hline \multicolumn{5}{|c|}{ Contribution to growth by factors of production (percentage points) } \\
\hline & $\mathrm{L}$ & $\mathrm{K}$ & TFP & $\mathrm{Y}$ \\
\hline 2008-2015 & 1.88 & 3.75 & 1.31 & 6.93 \\
\hline 2016-2022 & 1.46 & 2.80 & 1.16 & 5.42 \\
\hline
\end{tabular}

Source: Fund staff calculations.

\section{Transforming Panama into a Global Logistics Hub: What can Panama Learn from Singapore?}

With the expanded Panama Canal, the associated transport and logistics infrastructure, the presence of the regional financial center, and a stable economic and political environment, Panama seems well placed to leverage its logistics sector as a source of future growth. This section considers Singapore's emergence as a global logistics center as a case study to identify lessons that Panama can draw upon to facilitate a similar transition.

\section{Panama's unique geographical location has endowed it with a comparative advantage} in logistics and transportation services. The interoceanic Canal, in particular, is an exceptional

\footnotetext{
${ }^{11}$ Contributions from labor and total factor productivity (TFP) are also expected to be somewhat smaller than in recent years. Labor's contribution is expected to moderate somewhat from 1.9 percentage points over 2008-2015 to about 1.5 percentage points over 2016-2022, which is consistent with the projected slight decline in population growth. TFP is projected to contribute about 1.2 percentage points, very similar to its contribution of 1.3 percentage points over the period 2008-2015.
} 
asset for leveraging development of logistics and transportation services given that about 5 percent of world merchandise trade transits the Canal. In addition, Panama has an extensive existing internal rail and road network connecting the two sides of the Canal that facilitate logistics and distribution. Panama's Tocumen International Airport also operates as a regional hub and offers opportunities for synergies with other modes of transportation.

20. Lessons from success stories on the world stage, such as Singapore's, can help Panama leverage its comparative advantage to transform Panama from a regional into a global logistics hub. Panama shares some important characteristics with Singapore: a favorable geographical location, economic and political stability, and openness to world trade. In addition, both countries have established port and airport connectivity as shown in Table 3. Such commonalities suggest that Panama can draw lessons from Singapore's transition into a global logistics hub to boost its logistics competitiveness and facilitate a similar transition.

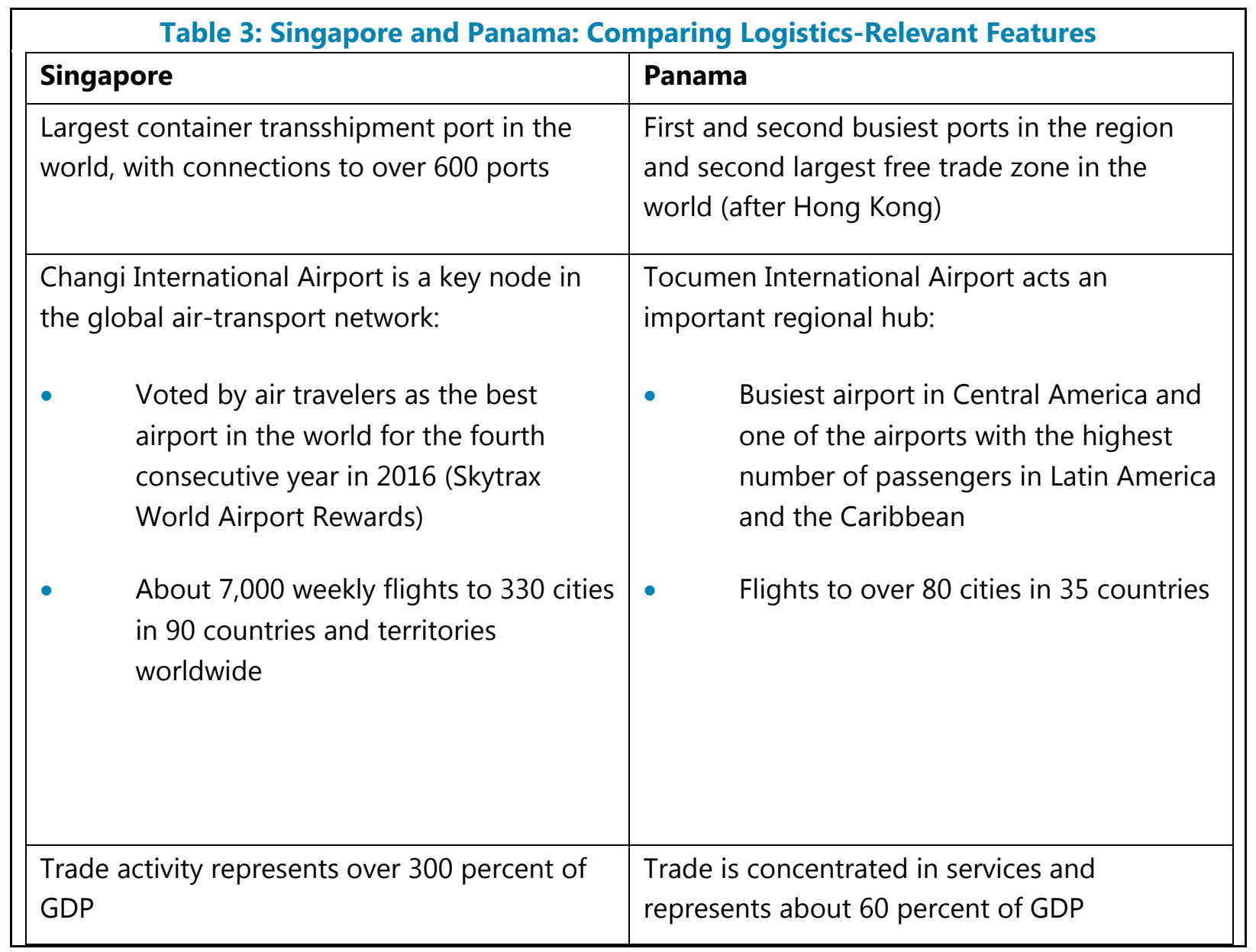




\section{Singapore's Success Story}

21. Singapore's transformation into a global logistics hub has promoted sustained and broad-based economic growth. Since gaining independence in 1965, Singapore's transformation into a central node on the world trade map has resulted in a broad economic expansion (text figure) that included different economic sectors. Singapore's model of development capitalized on important synergies between related sectors including transportation and storage, financial intermediation, insurance, and information and communication technologies. Consistent with the growth strategy focused on these related sectors, they were the key drivers of economic activity. The development of the worldclass services sector also produced positive spillovers into manufacturing and construction and contributed to a broad-based expansion of economic

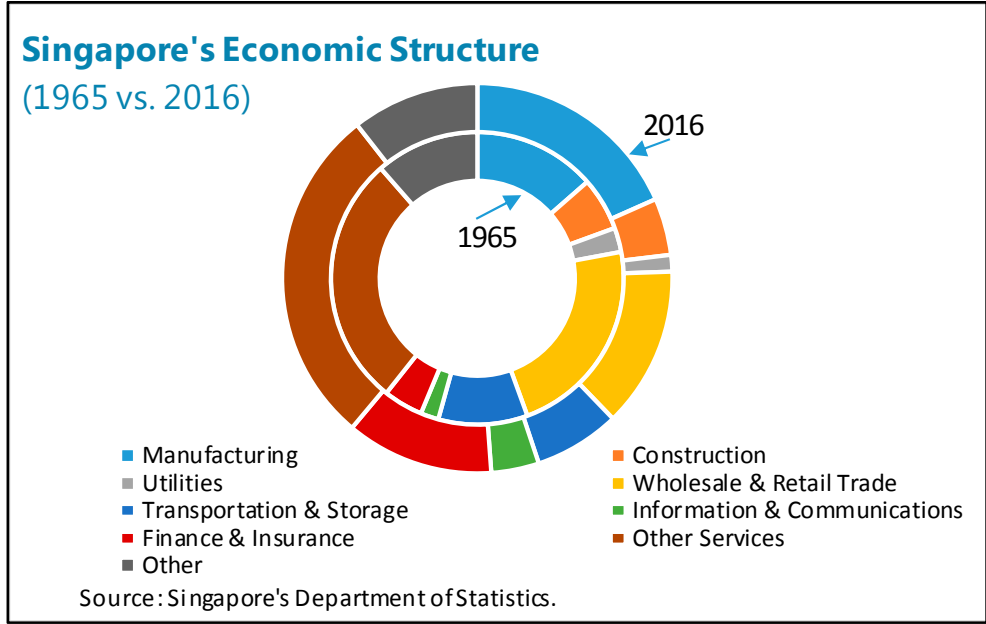
activity.

\section{The continued re-invention of Singapore's model helped sustain double-digit growth} in various sectors. The ability to add new activities and facilitate incremental changes contributed to maintaining strong growth in both services and industry. In addition, various segments of the services sector registered double-digit growth rates, set against the backdrop of positive synergies and mutual reinforcement among transport and logistics, financial intermediation, insurance, and ICT (text figure).
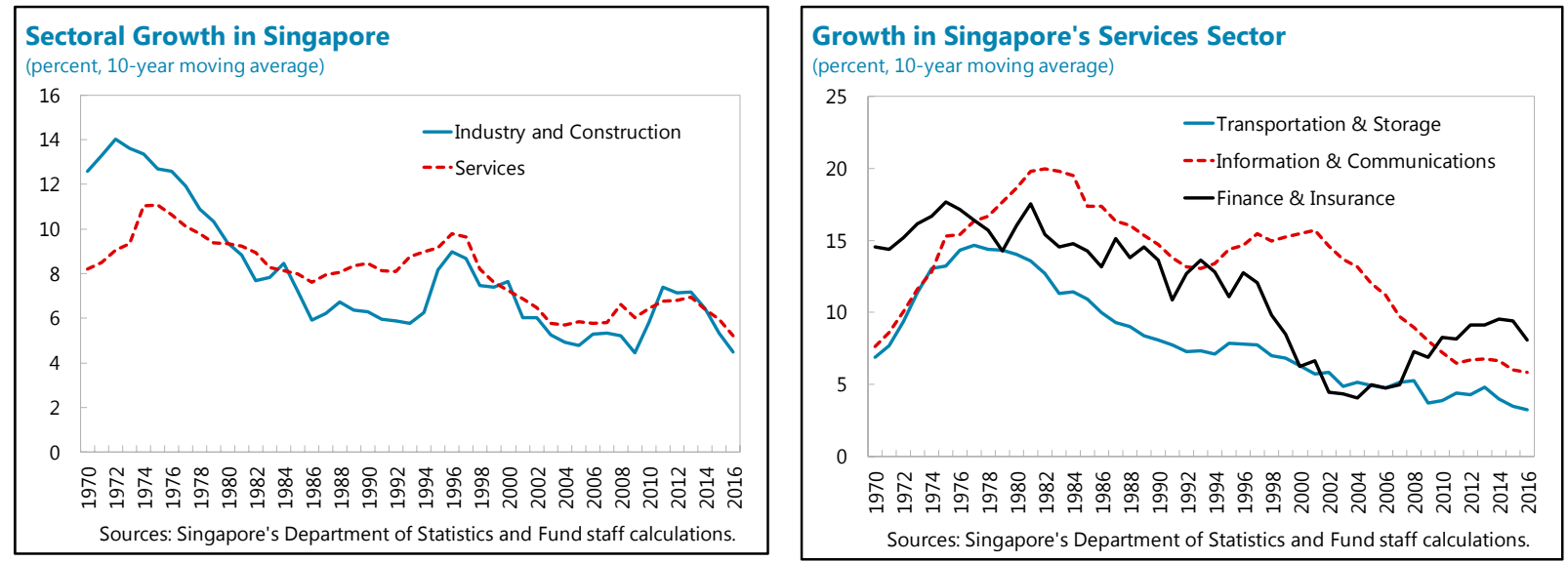

23. Singapore's success story reflects its ability to leverage its strategic geographical location through synergies between public policy and private sector involvement. Lam and Ramakrishnan (2017) elaborate that Singapore's successful transformation into a global logistics hub 
has been the result of three key factors: connectivity, world-class infrastructure, and encouragement of private sector participation. First, connectivity has been strengthened as the maritime and civil aviation authorities expanded Singapore's maritime and flight connections network through enhanced cooperation with foreign authorities, shipping companies, and the conclusion of aviation agreements with over 130 states and territories. At the same time, the country built an extensive network of free-trade agreements with over 30 economies, which further boosted its connectivity. Second, infrastructure has been continually strengthened with one of the largest and most sophisticated ports in the world, an airport that facilitates air cargo with the latest technological solutions for storage of perishable and sensitive materials, and the world's first single window system to support trade facilitation and streamline issuance of permits. Third, the authorities have encouraged direct involvement of the private sector in public decision-making process. For instance, public investment projects have been subject to an extensive consultation process to ensure that they meet the business sector's needs and can induce private investment in complementary infrastructure.

\section{Where Does Panama Stand?}

\section{With adequate policy actions Panama has an opportunity to follow Singapore's} example. Panama's connectivity is at the top in the region, with the two busiest ports in the region, Tocumen International Airport as the regional air-transport hub, and many important telecommunication/internet optical fiber cables passing through the Canal. Numerous multinational companies have chosen Panama for HQs of their (regional) operations, and its dynamic financial center can provide necessary impetus to strengthen synergies across sectors. Panama has also concluded over a dozen free-trade agreements that cover trade relations with over 40 countries and territories (including with Singapore).

25. The expanded Canal is expected to unlock new growth opportunities. The expanded Canal opens opportunities for emerging activities, such as LPG and LNG vessels, which are among the fastest-growing user segments. and may have spillovers to related industries. In particular, the Canal could support further development of Panama's ports and logistics industry, provided it does not cannibalize such activity as the larger vessels transit directly from source to destination, especially between Asia and North America. Continued improvements in infrastructure and capacities to offer new services are likely to be the key components of a strategy to maintain and enhance Panama's position as an attractive destination for logistics and distribution.

\section{Panama has narrowed its gap in container traffic and shipping connectivity relative to} the world's major ports. While total container traffic through Panama's ports is about one fifth of Singapore's, Panama's growth has been significantly faster than Singapore's over the last decade. Panama has also managed to narrow its connectivity gap relative to the world's top ports over the last decade according to the World Bank's liner shipping connectivity index, though it still lags behind all 5 top ports. 

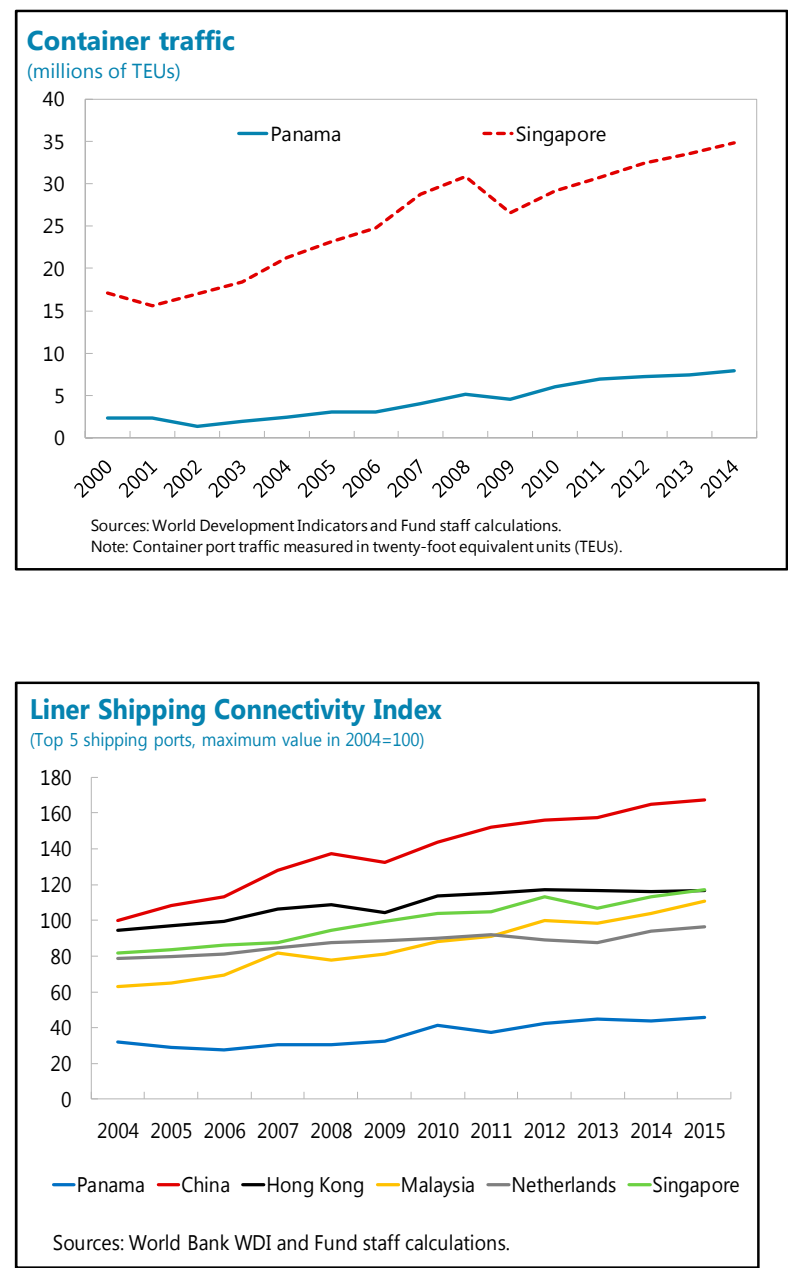
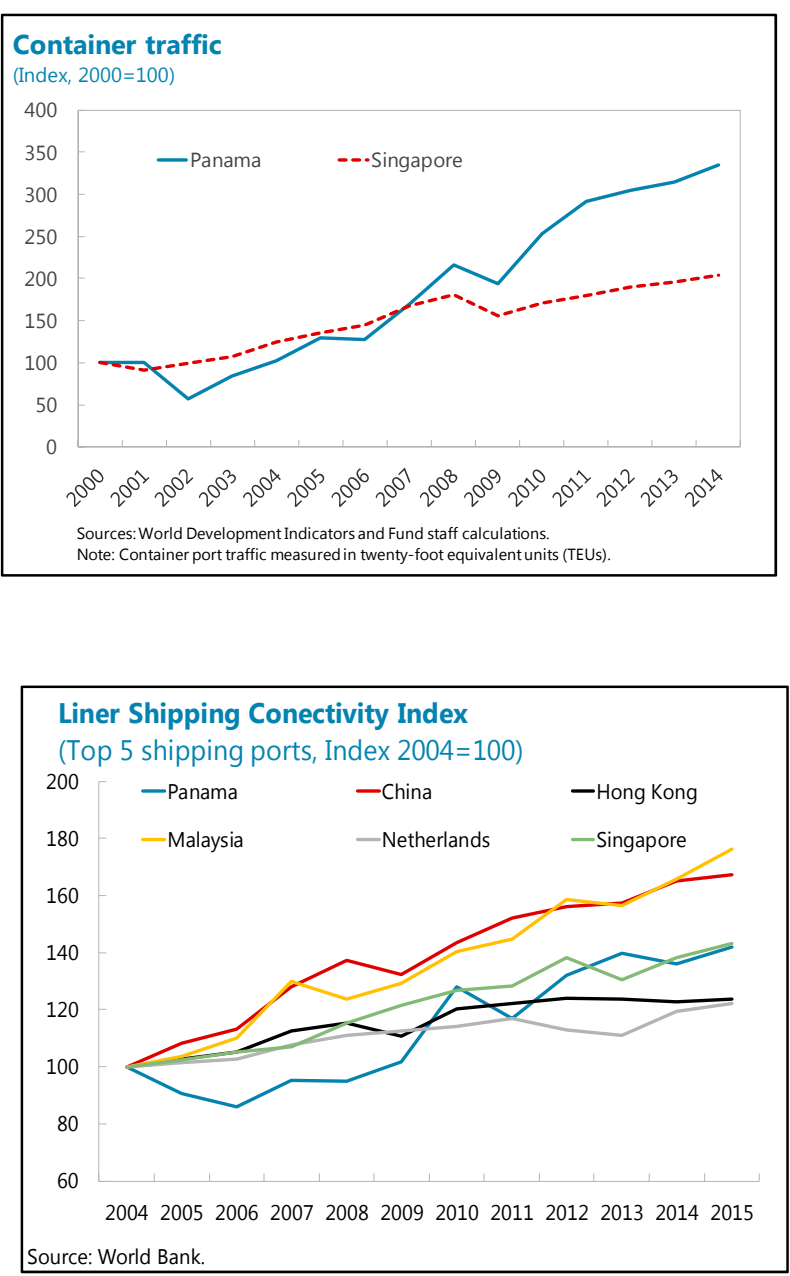

\section{Panama's significant improvement in logistics performance over the last decade has} established its competitive advantage as a logistics hub compared to its neighbors in Latin America, though still significantly behind Singapore. The Logistics Performance Index suggests that Panama's progress since 2007 was broad-based, with improvement in logistics quality and competence, cross-border shipments, infrastructure and customs. Panama has also managed to narrow its gap relative to Singapore in many areas relevant for logistics performance, such as crossborder shipping, infrastructure, and logistics quality and competence. Nonetheless, a significant gap remains in most logistics segments, including customs efficiency, timeliness, tracking and tracing, and infrastructure. ${ }^{12}$

\footnotetext{
12 Closing the LPI gap relative to Singapore implies reducing the distance to the global frontier as Singapore is
} consistently among the world's top performers on various logistics indicators. 

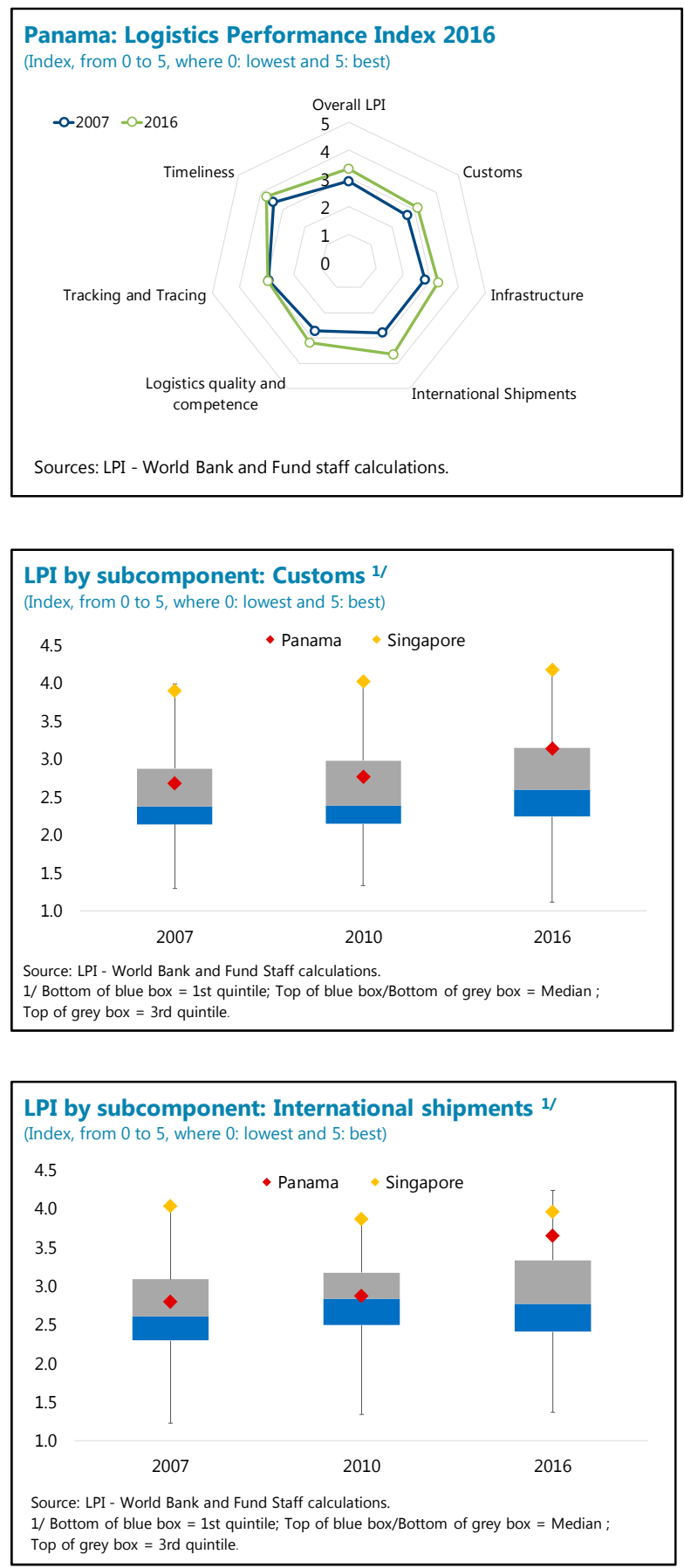
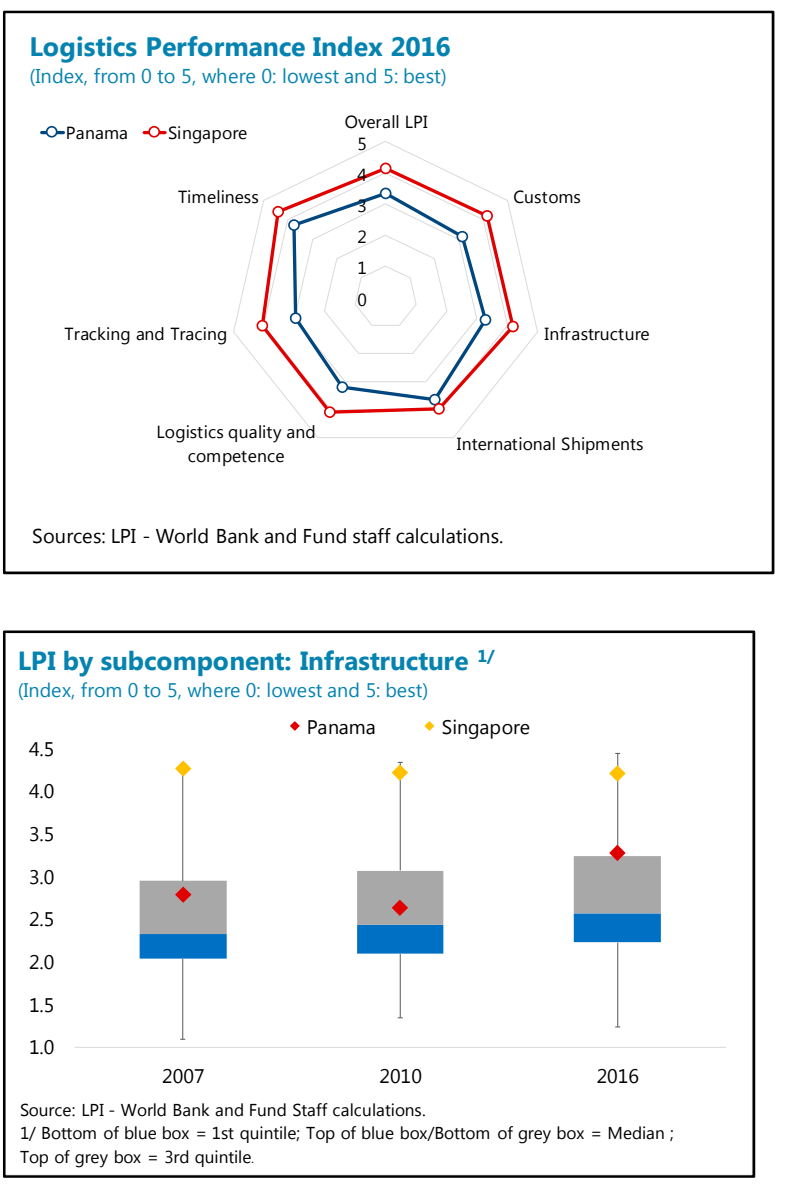

LPI by subcomponent: Logistics quality and competence ${ }^{1 /}$ (Index, from 0 to 5, where 0: lowest and 5: best)

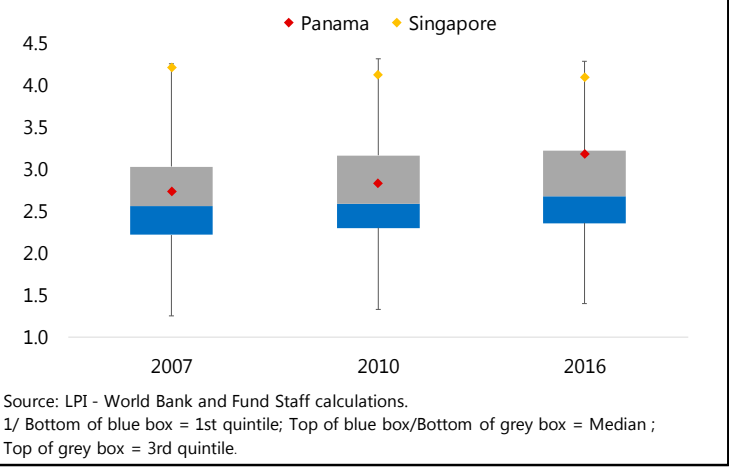

28. More generally, policy actions that strengthen the business environment and improve competitiveness also incorporate key measures that are needed to address challenges in transforming Panama into a global logistics hub. Such policy areas include general strengthening of institutions, enhancements in the education system and infrastructure quality, strengthened contract enforcement, better capacities to absorb new technologies, and the promotion of a culture of paying taxes. Beyond the narrow area of improving logistics performance, effective measures to 
tackle challenges in these policy areas are likely to also boost Panama's opportunities in other economic sectors, create synergies, and help Panama continually re-invent its business model.
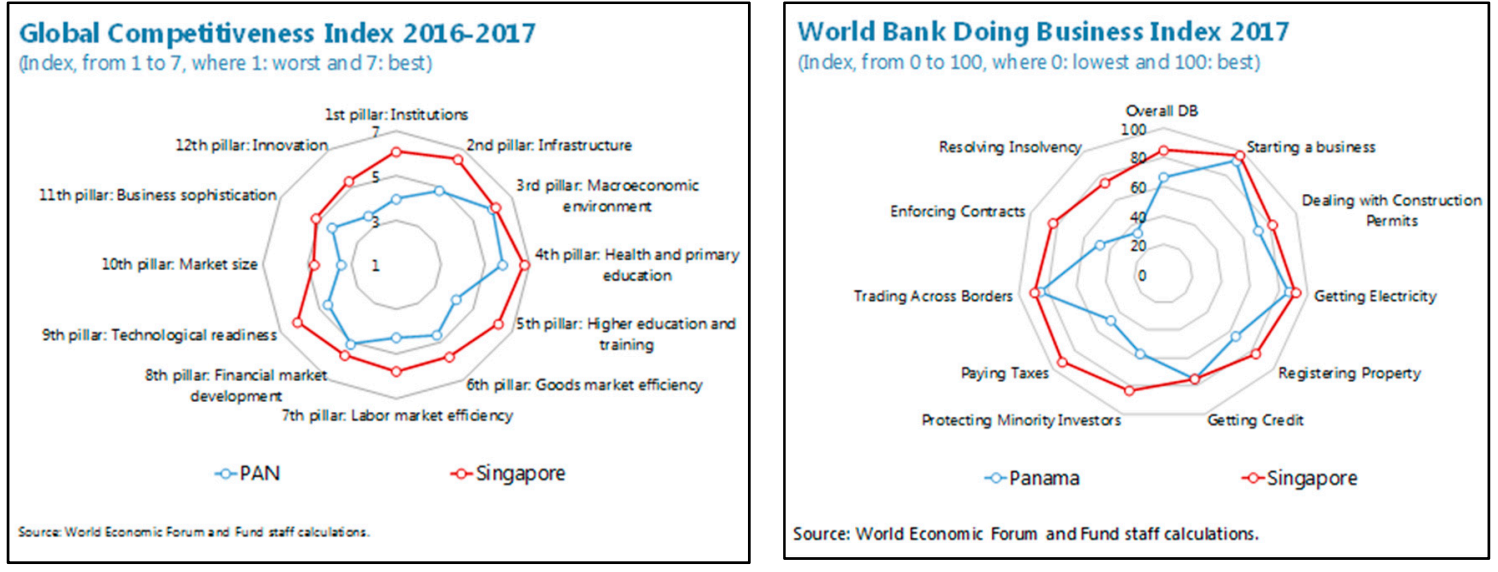

\section{Leveraging Connectivity to Strengthen Tourism}

Tourism is an important, yet underdeveloped, sector in the Panamanian economy. Panama has an advantageous climate and diverse ecosystem combined with a major metropolitan area attractive to a diverse tourism clientele. With Panama's role as a regional transportation hub, there is a unique opportunity to leverage Panama's connectivity to strengthen its tourism industry. This section takes stock of the Panamanian tourism sector, its competitiveness and recent performance and makes concrete recommendations to leverage Panama's existing strategic advantages to boost the economic contribution of the sector and diversify its product in support of Panama's inclusive growth objectives.

\section{Panama's Tourism Sector - Taking Stock}

\section{Tourism is an important sector in the Panamanian economy, yet underrecognized as}

such. The World Travel and Tourism Council (WTTC) estimates that tourism's total contribution to output is a sizeable 17 percent of GDP. ${ }^{13}$ While Panama is not widely appreciated as a tourist destination, this is larger than the average of the tourism-dependent economies of the Caribbean as well as Panama's neighbors in Central America. The tourism industry is also a major employer: tourism is estimated to account for about 12 percent of total employment, making it one of the largest employment-generating industries in Panama. About 3 percentage points of the contribution of tourism to employment is directly related to jobs in hotels and restaurants and other tourist

\footnotetext{
${ }^{13}$ The total effect includes activity directly related to the tourism industry, estimated at about 8 percent of GDP, as well as spillover effects from the tourism onto other industries, estimated at about 9 percent of GDP. These latter effects included the sum of capital investment spending by all industries directly involved in travel and tourism, government spending in support of tourism (including promotion and visitor information services) and supply-chain effects from purchases of domestic goods and services directly by different industries within travel and tourism as inputs to their final tourism output.
} 
activities, while the remainder is associated with supply-chain effects from tourism's linkages with other industries.
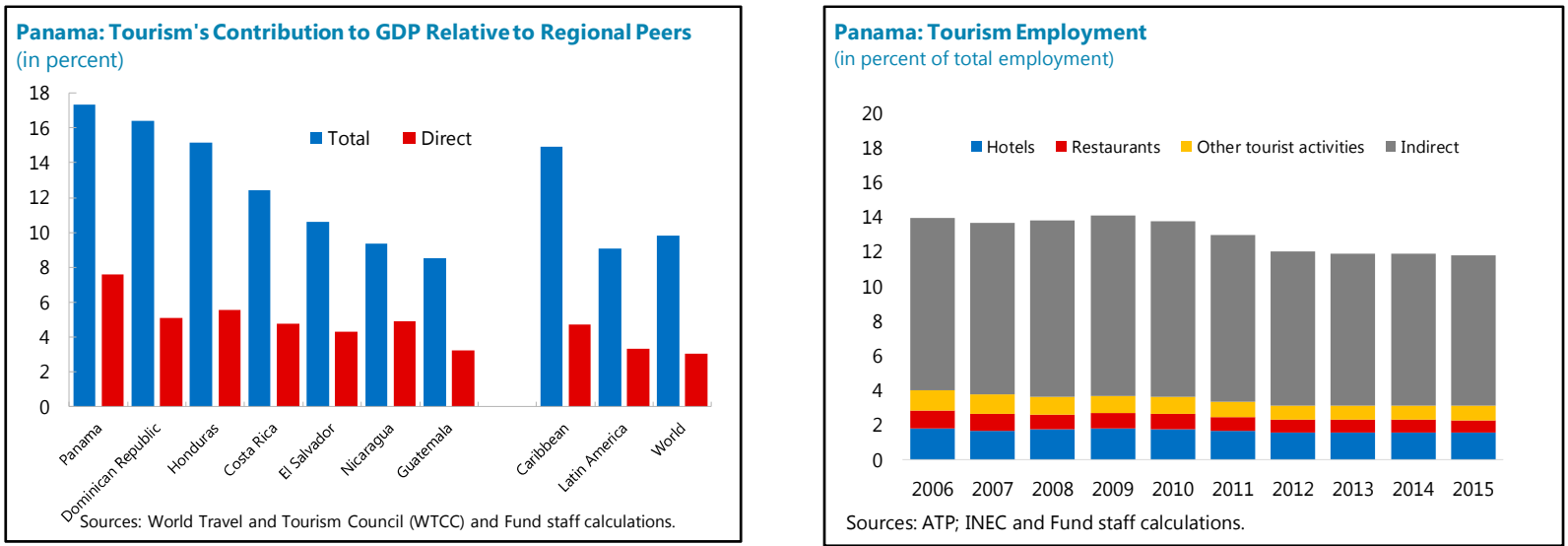

30. Tourism performance is closely tied to economic developments in Latin America and the Caribbean where the majority of tourists to Panama originate from. Almost 60 percent of tourists originate from the region. South America is by far the most important market: 46 percent of total arrivals in 2015 originated in South America compared to 10 percent from Central America and 2 percent from the Caribbean. ${ }^{14}$ South America's market share expanded rapidly from 2006 to 2013 as the region's commodity exporters benefited from the commodity price boom and expanded their demand for Panama's tourism services. The increase in market share partially reversed course beginning in 2014 as the region began to adjust to the sharp drop in commodity prices that began that year, but, in 2015, South American tourists still accounted for 11 percentage points more of total tourist arrivals than they had in 2006. The more recent loss of market share is also likely related to the sharp depreciation of the region's currencies relative to the U.S. dollar, which has made Panama a more expensive destination for the region's tourists. ${ }^{15,16}$ The region is expected to gradually emerge from its regional recession in 2017, but

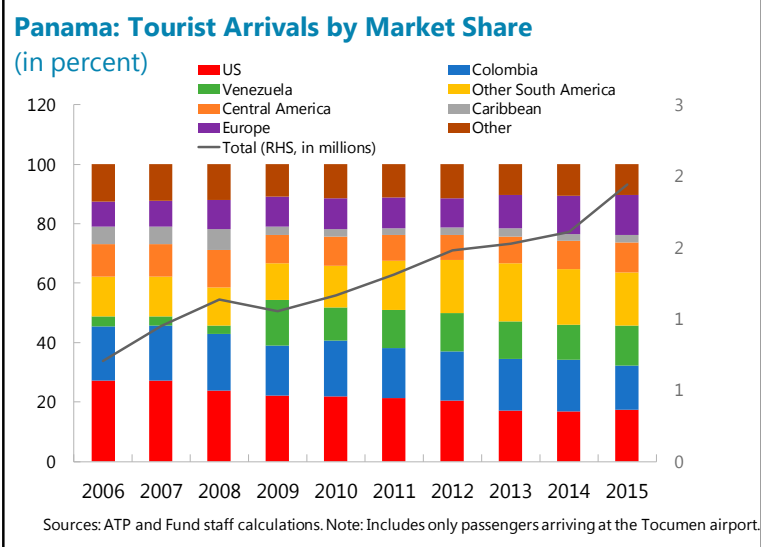
with commodity prices expected to remain low,

\footnotetext{
${ }^{14}$ Data on the country of origin of tourists to Panama is only available for those tourist arriving through the Tocumen airport and excludes cruise passengers and passengers arriving by land. With passengers arriving by land representing 6 percent of total arrivals, the market share of Latin America and the Caribbean tourist in Panamanian tourism is likely understated by these statistics.

${ }^{15}$ Colombia, which represents about 30 percent of South American arrivals or 15 percent of total arrivals, accounted for the majority of the decline in the region's overall market share.

${ }^{16}$ Laframboise and others (2014) show that tourism arrivals and expenditure are sensitive to both price and income factors in source markets.
}

(Continued) 
the regional outlook remains relatively subdued, suggesting that any impact on demand for Panama's tourism services is likely to be limited. ${ }^{17}$

31. The U.S. is also an important market for Panamanian tourism. In 2015, 17 percent of tourism to Panama originated in the U.S. However, the importance of the U.S. market has declined over time: its market share declined about 10 percentage points since 2006 . This decline is the direct counterpart of the rise in importance of the Latin American and Caribbean market and reflects the strong growth of that segment compared to the U.S. market rather than a decline in tourists from the U.S. More generally, dollarization has been a boon to the U.S. segment, generating stability in the price of the Panama's tourism product for U.S. tourists. In this context, trends in U.S. arrivals appear to have been primarily driven by developments in the U.S. economic cycle and, with the U.S. recovery poised to continue, should drive a continued increase in arrivals from the U.S. market. ${ }^{18}$

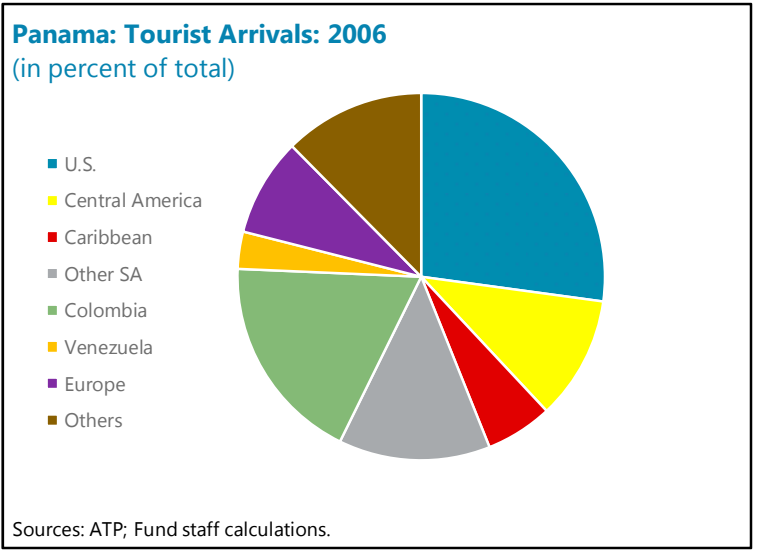

32. Leisure travel dominates visitors' motivation for travelling to Panama. Business travel, including for conventions, has also traditionally been an important factor driving tourists to Panama and, with a new convention center nearing completion, this segment is expected to increase in importance going forward. ${ }^{19}$ Tourism remains concentrated in Panama City, which with the development of the retail industry, has transformed Panama City into a major shopping destination for Latin America. While data on the percent of room stock is not
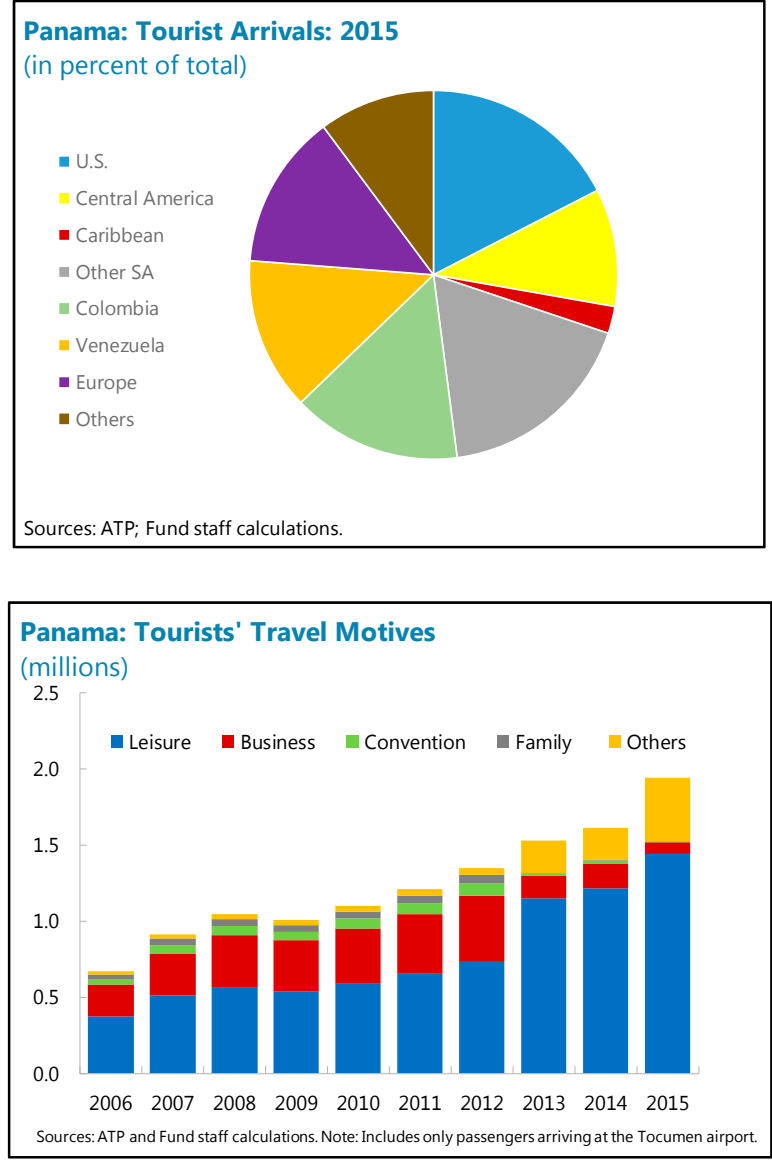

${ }^{17}$ The January World Economic Outlook from the IMF projected growth of 1.2 and 2.1 percent for the Latin American and Caribbean region for 2017 and 2018, respectively.

18 The January World Economic Outlook from the IMF projected growth of 2.3 and 2.5 percent for the United States for 2017 and 2018, respectively.

${ }^{19}$ While the importance of business travel appears to have declined since 2013, this appears to be related to a statistical issue rather than a general trend. 
available, over 40 percent of tourist accommodations are located in Panama City. Given the concentration of large hotels in the capital, this likely significantly understates the importance of Panama City as the main tourist destination within Panama. Tourism remains under-developed throughout the remainder of Panama, although Chiriqui and Bocas del Toro have grown in popularity. On average, tourists tend to stay in Panama for about 8 and a half days and spend about US $\$ 270$ a day or over US $\$ 2300$ for the duration of their stay.

33. Panama remains an affordable travel destination. The appreciation of Panama's real effective exchange rate, driven to a large extent by the appreciation of the U.S. dollar, has diminished the price competitiveness of Panama's tourism industry; however, other indicators suggest that Panama remains an affordable destination. The 'Week-@-the-Beach' (W@tB) Index compares nominal-in-country costs of a typical basket of beach/holiday goods/services with common standards, from a common source and in a common currency (Laframboise and others 2014 updated to January 2017). The index suggests that Panama compares favorably in price to Central and South American destinations and the tourism-dependent Caribbean. However, Panama's relative performance in the index may be distorted by differences across tourism products: while the tourism offerings of regional comparators are primarily concentrated in relatively more high-end beach resorts, Panama's tourism industry has primarily been driven by tourism to Panama City as a shopping destination. In this context, Panama's REER may better reflect developments in the relative competitiveness of its tourism industry.
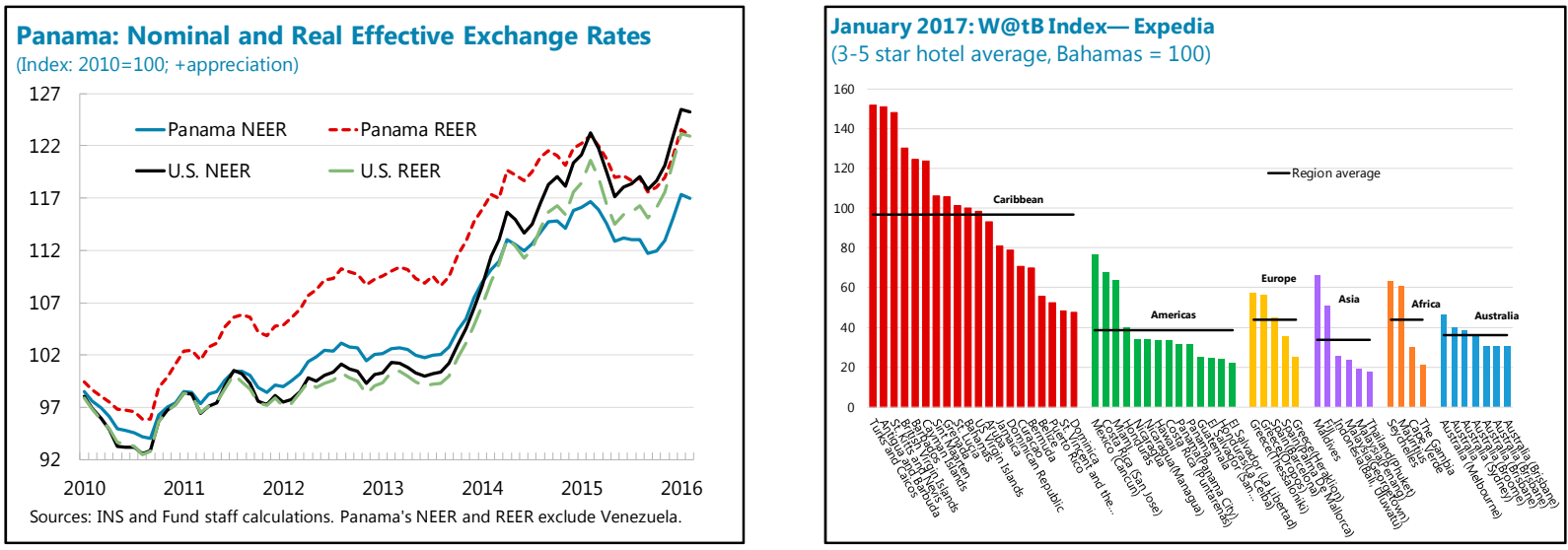

\section{Performance of the Tourism Sector}

\section{Tourism performance has been affected by regional developments and the}

appreciation of the U.S. dollar. Total tourism arrivals declined in 2016 relative to their earlier year level as the industry was hurt by the recession in Latin America and the appreciation of the U.S. dollar. Hotel occupancy rates (at 52 percent in 2015) are also low, although this primarily reflects historical over-investment in the hotel room stock, particularly in Panama City, rather than the downturn in arrivals. However, despite the decline in arrivals, tourism receipts rose by 5.6 percent, down from 12.8 percent in 2015. As a result, Panama continued to grow its market share of total tourism expenditure in Latin America and the Caribbean, both in leisure and business tourism. 
Relative to tourism competitors in CAPDR, however, Panama's market share has been stable since 2012.
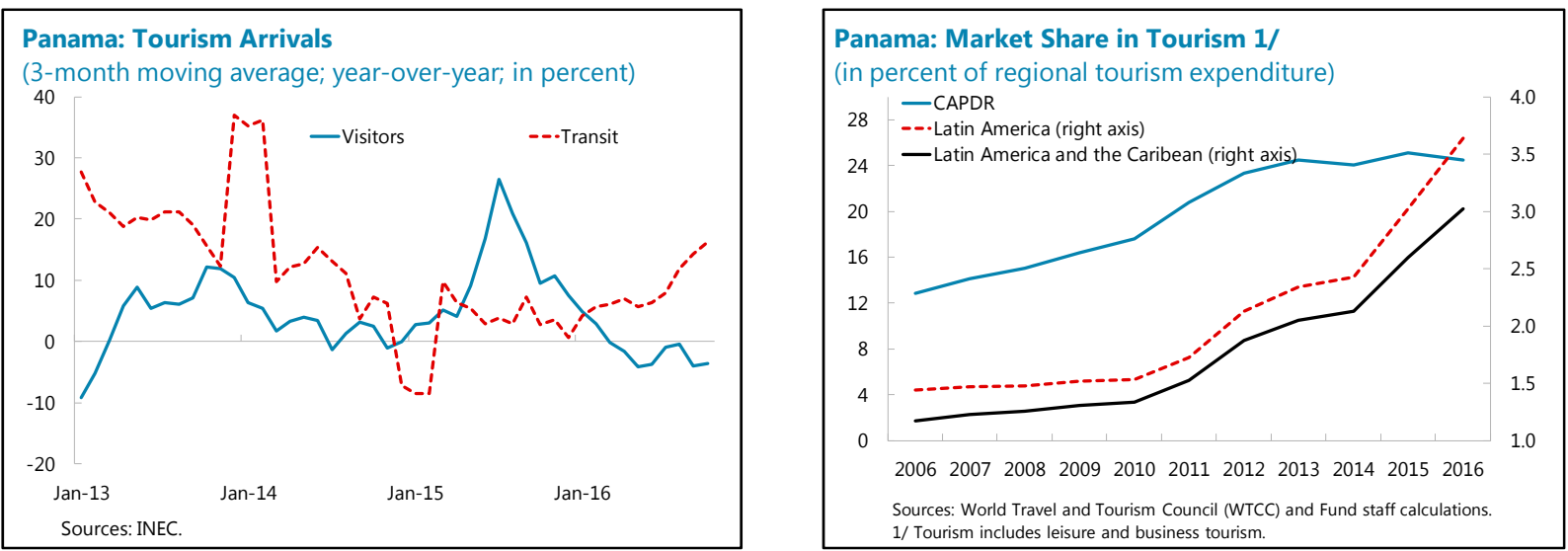

\section{Opportunities to Strengthen Panama's Tourism Sector}

35. Panama is well positioned to grow its tourism sector. Relative to other tourist destinations in the region, Panama has two important comparative advantages that have yet to be fully exploited: (1) its strategic geographical position that has transitioned Panama into a regional transportation hub and (2) an advantageous climate and diverse ecosystem combined with a major metropolitan area attractive to a diverse tourism clientele.

\section{Panama's connectivity should be leveraged to enhance the tourism sector. Panama's} Tocumen airport is a regional hub, but only about 10 percent of travelers transiting through the airport visit Panama. With tourists spending an average of US $\$ 270$ a day, capturing even a small share of transiting passengers as tourists holds considerable potential to boost economic growth. The ongoing extensive expansion of the Tocumen airport, expected to be opened in 2018, provides an opportunity to capitalize on the increased volume of transiting passengers through the Tocumen airport to grow the domestic tourism sector. The expansion will boost airlift supply, which Acevado and others (2015) have shown to be the most effective way to boost tourist arrivals on sustained basis. Iceland offers potential important lessons for Panama in this regard. Through strategic partnerships with airlines, including through free stopovers, Iceland has successfully increased tourism by marketing itself as a stopover destination for passengers transiting to other destinations. In addition, the opening of the expanded Canal provides an opportunity to grow the cruise segment. To successfully develop the cruise segment, supporting infrastructure will need to be put in place. Positioning Panama as a home port, through the development of a new cruise terminal, could pay dividends in this regard.

\section{Diversifying Panama's tourism product can support tourism development and} inclusive growth. Tourism to Panama remains concentrated in Panama City despite the attractiveness of Panama's diverse ecosystem for the development of a broad range of tourism products including beach and eco-tourism. Diversifying the tourism product with require enhancing connectivity within Panama to support development of the sector outside of Panama City. 
Otherwise, a two-pronged strategy is needed that focuses both on strengthening marketing efforts of Panama's diversified tourism product while encouraging development of tourism operators. Development of the cruise industry also has potential to have spillover effects to facilitate diversification of Panama's tourism product as new products may be developed in response to cruise passengers' demand for diverse excursions. Finally, diversifying Panama's tourism beyond Panama City, where it has been concentrated, can also support inclusive growth and a reduction in the significantly higher poverty rates in rural areas it may also encourage diversification of Panama's main tourism markets and help to reduce spillovers to Panama from developments in individual tourism source markets.

\section{E. Conclusions}

\section{Panama is well-placed to maintain its business model founded on its competitive} advantage as an attractive destination for international financial, business and transportation services. Panama's historical success has been based on its strategic geographical position, which has been exploited to transform Panama into a transportation hub, while the favorable business environment has facilitated Panama's emergence as a regional business center. To further cement Panama's competitiveness, the results of the growth diagnostics exercise point to the need to improve the quality of education, strengthen governance and reduce bureaucracy. The most important challenge will be to advance reforms to the education system to ensure that it is able to supply workers with the skills demanded in Panama's economy, particularly as Panama continues its transition to a modern service-based economy.

\section{Panama's connectivity can be leveraged to strengthen its logistics and tourism}

industries. Panama shares some characteristics with Singapore: a favorable geographical location, economic and political stability, a network of free trade agreements, and established port and airport connectivity. Thus, Panama could draw on lessons from Singapore's transition into a global logistics hub to boost its logistics competitiveness. The expanded Canal could also support further development of Panama's ports and logistics industry, provided it does not cannibalize such activity as the larger vessels transit directly from source to destination, especially between Asia and North America. The tourism industry has high potential for growth based on Panama's connectivity. Tocumen airport is an important regional hub, but only about 10 percent of travelers transiting through the airport visit Panama. Capturing even a small share of transiting passengers as tourists holds considerable potential to boost economic growth. In addition, the expanded Canal provides an opportunity to grow the cruise segment. Diversifying Panama's tourism beyond Panama City, where it has been concentrated, by developing beach and eco-tourism can also support inclusive growth and a reduction in the significantly higher poverty rates in rural areas. 


\section{References}

Acevedo, Sebastian, Lu Han, Hye Sun Kim, and Nicole Laframboise. 2016. "Flying to Paradise: The Role of Airlift in the Caribbean Tourism Industry". IMF Working Paper No. 16/33.

Bom, P.R.D. and J.E. Ligthart (2014), "What Have We Learnt from Three Decades of Research on the Productivity of Public Capital?", Journal of Economic Surveys, 28 (5), pp. 889-916.

Cerra, Valerie, Alfredo Cuevas, Carlos Goes, Izabela Karpowicz, Troy Matheson, Issouf Samake, and Svetlana Vtyurina. 2016. "Highways to Heaven: Infrastructure Determinants and Trends in Latin America and the Caribbean," IMF Working Paper No. 16/185.

Laframboise, Nicole, Nkunde Mwase, Joonkyu Park, Yingke Zhou. 2014. "Revisiting Tourism Flows to the Caribbean: What is Driving Arrivals?". IMF Working Paper No. 14/229.

Lam, Y.Y. and K. Ramakrishnan (2017), "Three Factors That Have Made Singapore A Global Logistics Hub", Transport for Development Blog, World Bank.

Pereira, A.M. and R.M. Pereira (2015), "Is All Infrastructure Investment Created Equal? The Case of Portugal", Working Paper 156, The College of William and Mary.

The Economist (2011), "Panama's Economy: A Singapore for Central America?", July 14, 2011. 
Figure A1.1: Infrastructure Quality Indicators Relative to GDP per Capita (2014) (Y-axis: Infrastructure quality index, 0 =worst, 7 =best; $\mathrm{X}$-axis: GDP per capita, PPP dollars, log-scale)

\section{Overall Infrastructure}

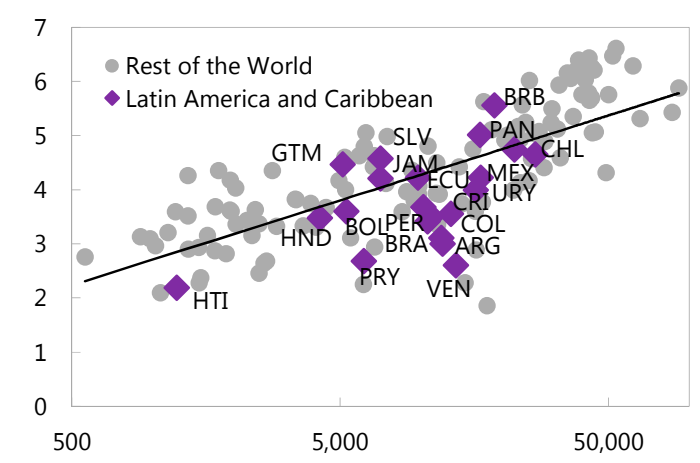

Roads

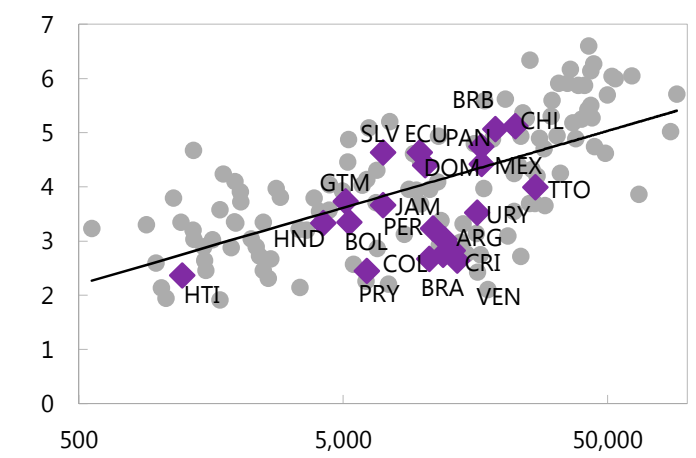

Air Transport

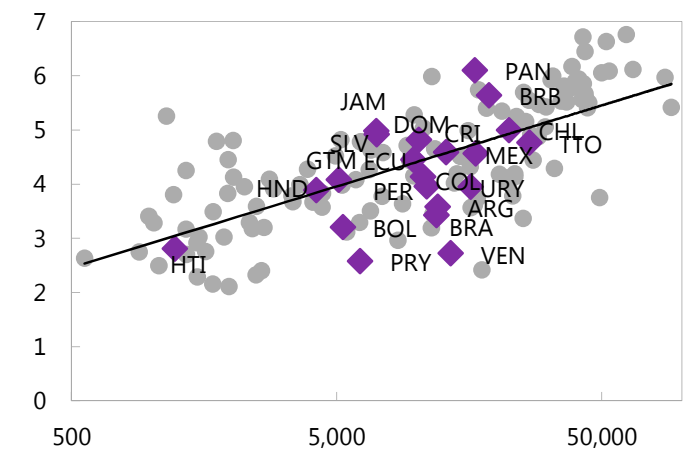

\section{Electricity Supply}

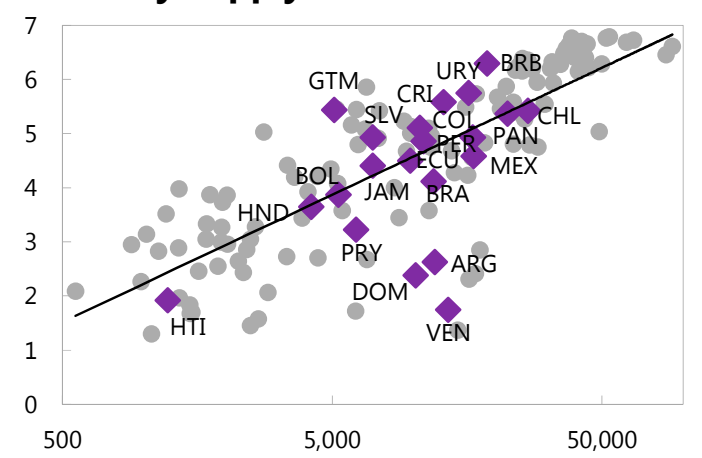

Railroads

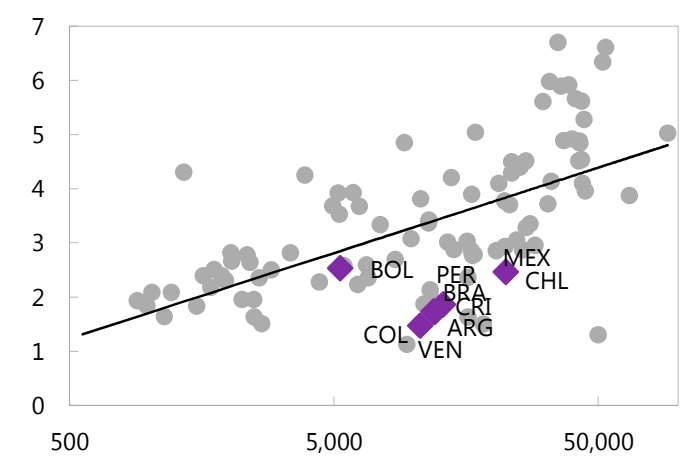

Ports

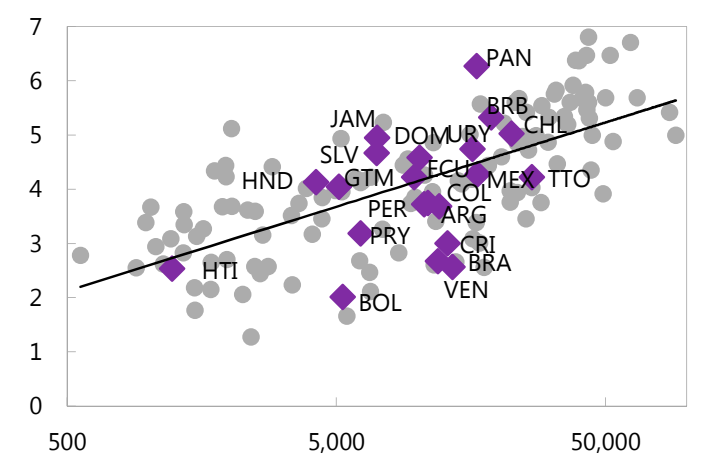

Sources: Cerra and others (2016). World Economic Forum; and IMF staff calculations. Note: ARG = Argentina; $\mathrm{BRA}=$ Brazil; $\mathrm{CHL}=$ Chile; $\mathrm{CRC}=$ Costa Rica; $\mathrm{COL}=$ Colombia; $\mathrm{DOM}=$ Dominican Republic; $\mathrm{ECU}=$ Ecuador; $\mathrm{ESV}=$ El Salvador; GTM = Guatemala; $\mathrm{HON}=$ Honduras; JAM = Jamaica; MEX = Mexico; NIC = Nicaragua; PAN = Panama; PRY = Paraguay; PER $=$ Peru; TTO = Trinidad and Tobago; URY = Uruguay $;$ VEN = Venezuela. 


\section{SPILLOVERS FROM EXTERNAL EXPOSURES TO} PANAMA $^{1}$

Panama is a small and open economy with a high level of integration into the international trade and finance network. It is exposed to global and regional developments through important linkages in trade, particularly in services, FDI and finance related to its role as a regional banking center. This paper first documents Panama's main external linkages and then provides a quantitative assessment of spillovers to Panama's economy stemming from its integration into the global economy. Economic developments in partner economies are found to have an important impact on Panama's economic performance. In particular, Colombia produces strong economic spillovers to Panama, with Colombian growth a key factor explaining Panama's economic growth. Exchange rate appreciation, for instance due to a stronger U.S. dollar, is found to have a stronger impact on goods exports than overall service exports.

\section{A. Panama's External Linkages}

1. Panama is among the most connected countries in Latin America. Considering together a broad range of different aspects of competitiveness, including trade, investment, information and people flows, the Global Connectedness Index suggests that Panama is the most connected country in Latin America. Out of 140 countries included in the index, Panama is ranked $47^{\text {th }}$. Panama's position in the index reflects its important linkages in trade, particularly in services, FDI and finance, the latter related to its role as a regional banking center. This section examines in turn four aspects of Panama's external linkages; trade, FDI, remittances, and finance.

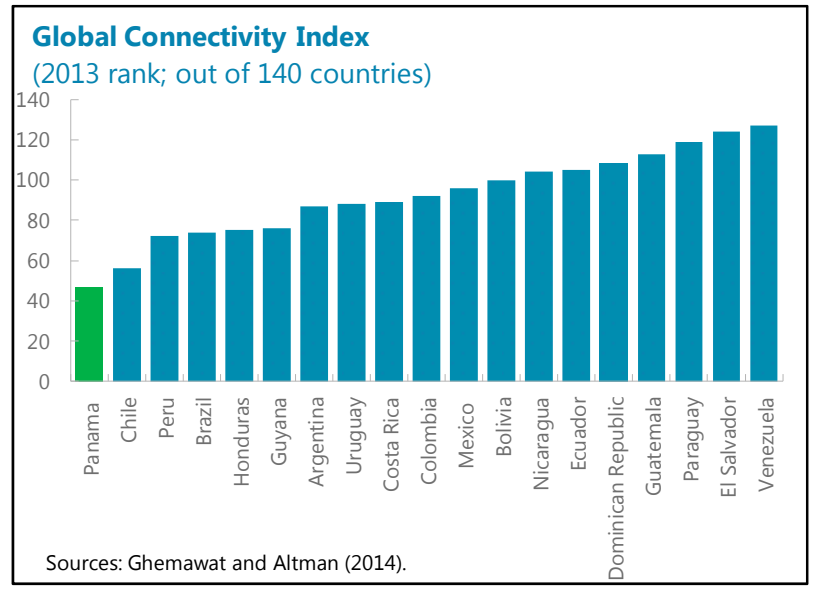

\section{Trade}

2. Panama is highly integrated through trade, primarily in services. While Panama runs a trade deficit in goods (of 16 percent of GDP in 2016) it runs a surplus in services (19 percent of GDP in 2016). Goods exports are small, at only 4.3 percent of GDP in 2016, down significantly from an average of almost 9 percent of GDP over the decade prior. This decline in exports is likely partly associated with a decline in competitiveness as Panama's real effective exchange rate has appreciated, mirroring developments in the U.S. dollar given dollarization. Re-exports from the Colon Free Zone have also lost competitiveness, falling to about 17 percent of GDP in 2016 from a

\footnotetext{
${ }^{1}$ Prepared by Kimberly Beaton and Metodij Hadzi-Vaskov.

2 The index is calculated as of 2013. See Ghemawat and Altman (2014).
} 
peak of 40 percent of GDP in 2011. Economic challenges in Venezuela and Puerto Rico and an ongoing trade dispute with Colombia have been key contributing factors to the decline in activity in the CFZ. Panama's service exports, in contrast, have remained stable, reaching 26.5 percent of GDP in 2016, consistent with the average level experienced over the prior decade. The continued strength of Panama's service exports, even while goods exports have been declining, suggest that, while Panama may have lost some competitiveness in goods exports, that its service exports remain competitive and may be less sensitive to movements in the exchange rate (see Section B for

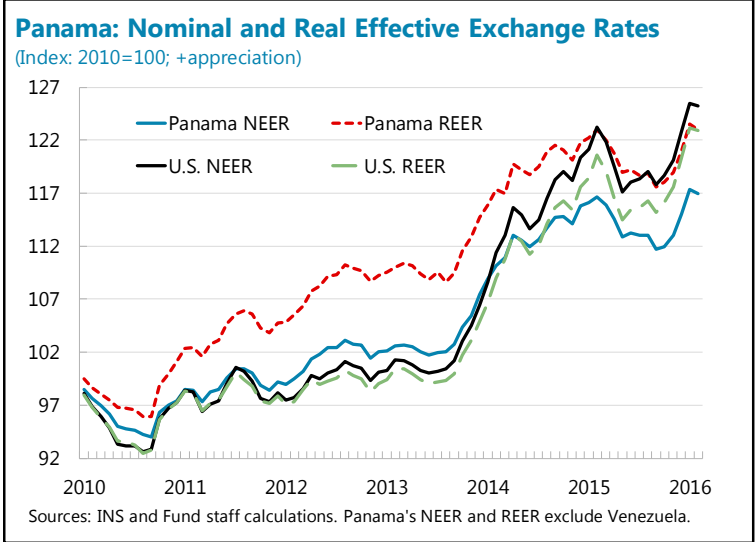
a quantitative analysis).
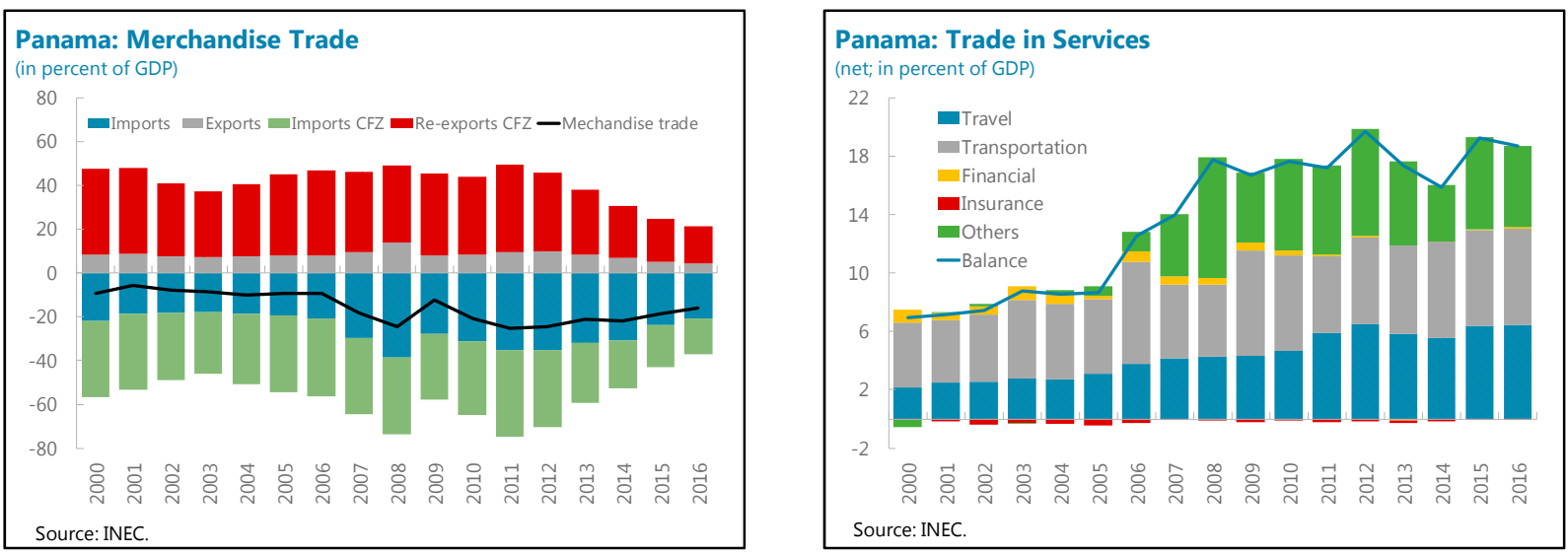

3. The U.S. remains Panama's most important trading partner, although Latin America is also an important destination for Panama's exports. The U.S. accounts for about 20 percent of merchandise exports, about 70 percent of total cargo transiting the Panama Canal, 17 percent of tourists, and 4 percent of CFZ re-exports. With the U.S. economy undergoing a gradual recovery, U.S. developments have recently been supportive of Panamanian exports, this has helped to offset the negative impact of the challenges faced by some of Panama's Latin American export markets. As a region, Latin America is the most important destination for Panama's exports. The region accounts for 26 percent of merchandise exports, 60 percent of tourists and at least 65 percent of CFZ exports. ${ }^{3}$ As a result of its intraregional trade integration, Panama's economic activity is sensitive to economic conditions in the region. For example, about three quarters of the decline in CFZ re-exports as a share of GDP since 2011 has been associated with regional developments.

\footnotetext{
${ }^{3}$ The decomposition of CFZ re-exports is not available for all re-export markets, with about 17 percent of re-exports categorized as to "other" markets. Of the CFZ export markets published by INEC for 2016Q4, Latin American economies accounted for over 65 percent of total CFZ re-exports.
} 
Figure 1: Panama's Trade Linkages

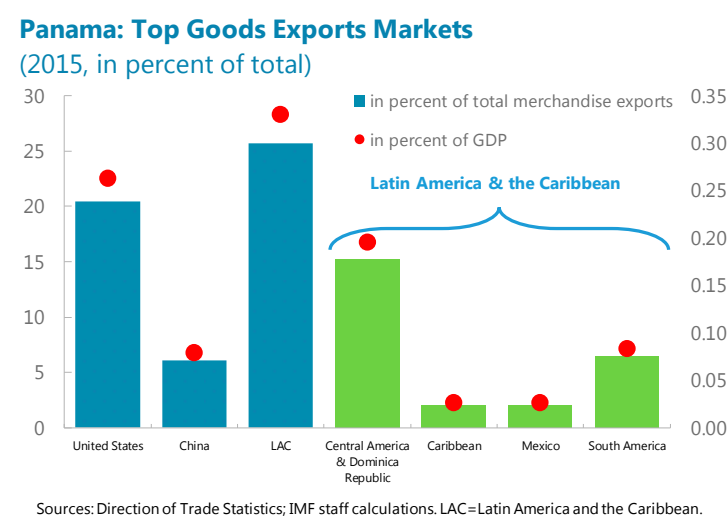

The United States, China and LAC countries account for 52 percent of total goods exports.

\section{Colon Free Zone}

(3-month m.a., year-over-year percent change)

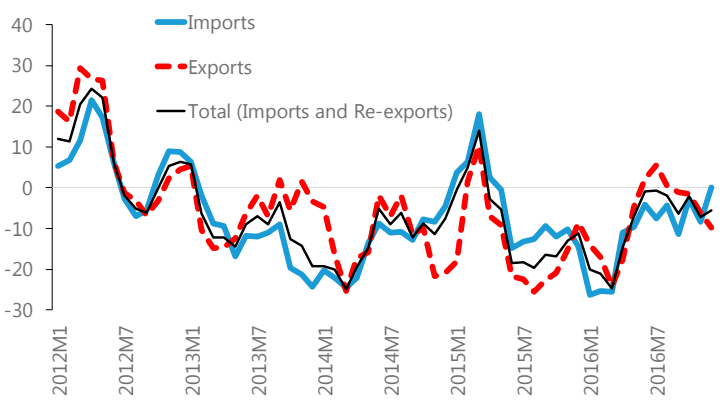

Source: INEC; IMF staff calculations.

Panama: Number of visitors

(annual growth rate, percent)

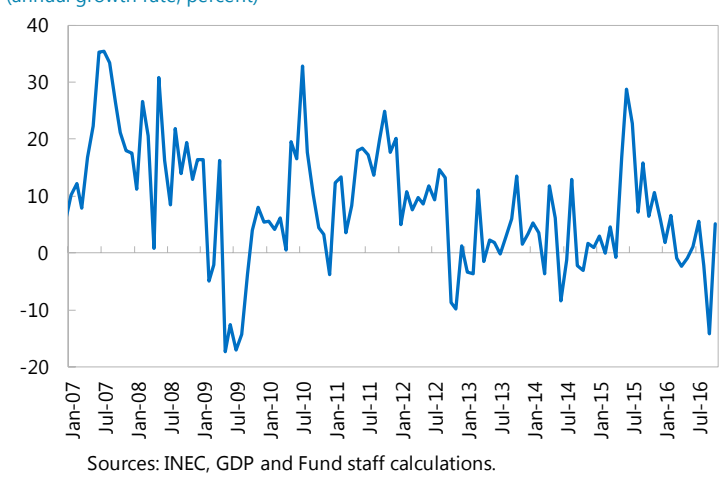

Panama: Tourist Arrivals by Market Share
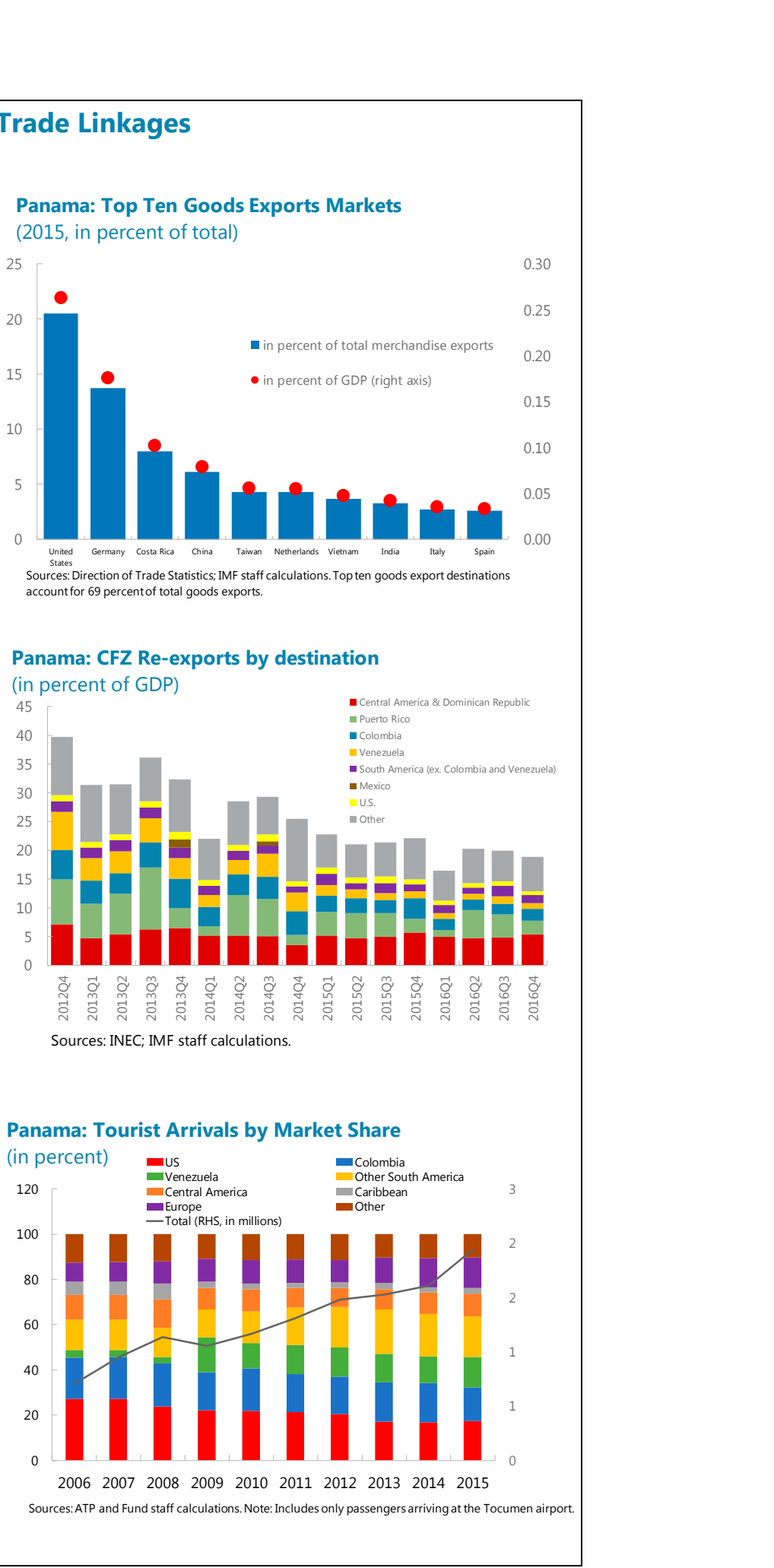

4. Panama's business cycle is closely linked to world trade. The Panama Canal is an important source of export receipts (4.3 percent of GDP in 2016) for Panama as ships pay a fee to transit the Canal. The amount of cargo transiting the Canal and toll revenue ultimately depend on world trade, which is expected to grow 4 percent on average over 2017-18, according to the World 
Economic Outlook (January 2016). About 5 percent of world trade transits the Panama Canal with about a third of ships transiting on the U.S. East Coast - Asia route, making traffic particularly sensitive to trade between the U.S. and Asia. Indeed, the U.S. accounts for over 70 percent of total cargo flows through the canal (including both origin and destination flows) with China accounting for a further 20 percent. Growing trade between Asia and the East Coast of Latin America may increase the sensitivity of Canal revenues to trade between these regions. Routes between these regions saw the largest increase in tonnage in 2016 and ongoing efforts to strengthen trade integration between the regions should facilitate a continuation of this trend. Canal revenue is also sensitive to commodity prices that alter the relative price competitiveness of other shipping routes. Low oil prices, for example, enhance the relative competitiveness of the Cape Horn route, and contributed to the poor performance of Canal revenues in 2016 despite the opening of the expanded Canal.

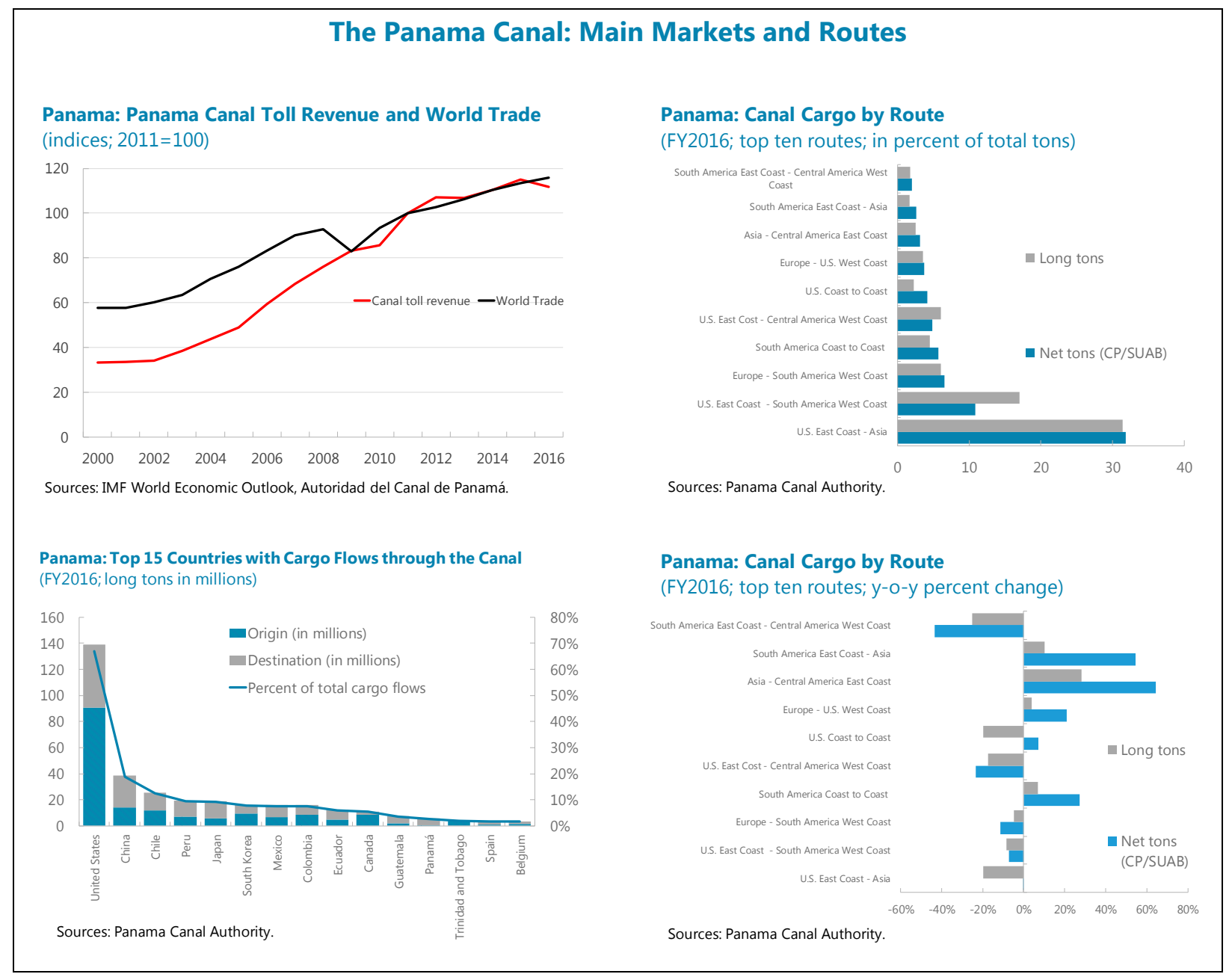

\section{Foreign Direct Investment}




\section{The United States and Colombia are also the most important providers of foreign} direct investment (FDI) to Panama. FDI, at 9.2 percent of GDP in 2016, is an important source of financing for the Panamanian economy. The United States provides about a quarter of this financing, with Colombia also accounting for just under a fifth of total FDI. FDI is primarily comprised of reinvested earnings of large multinational corporations operating in Panama. Thus, the stability of these inflows depends on the continued profitability of these firms and these inflows may be affected by taxation policies in these firms' home countries. Along these lines, the new U.S. administration's proposed changes to U.S. corporate tax rules could present a risk to these inflows if they encourage firms to relocate their operations in the U.S. At the same time, however, at the same time any decline in FDI receipts under the capital account is likely to be offset by a decline in outflows under the income account. FDI is well diversified across industries.
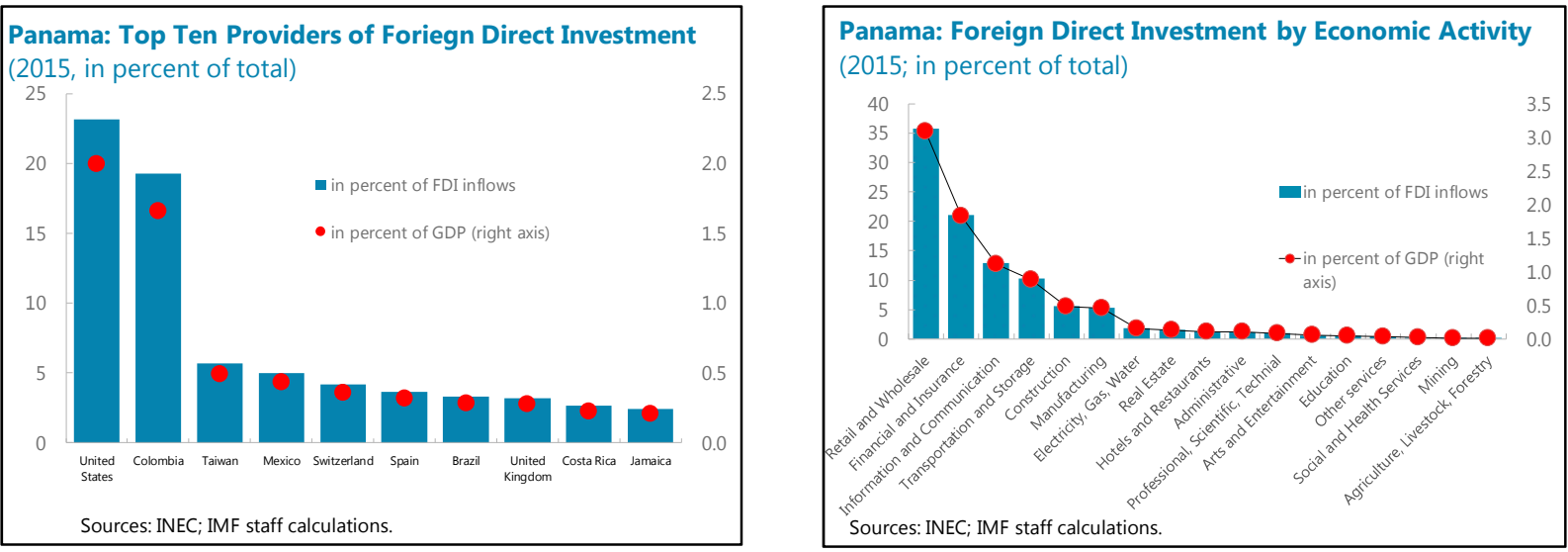

\section{Remittances}

\section{Panama receives important remittances inflows, but these flows are unlikely to be a} major transmission channel of international developments. In 2016, remittances amounted to 0.8 percent of GDP. The United States is by far the largest sender of remittances to Panama, accounting for about 35 percent of remittances. Otherwise, reflecting intra-regional patterns of migration, Panama also receives remittances from several neighboring countries in Latin America, with no single country dominating these flows. With a diverse set of countries sending remittances to Panama, remittances are unlikely to be a major transmission channel for international developments to Panama. 

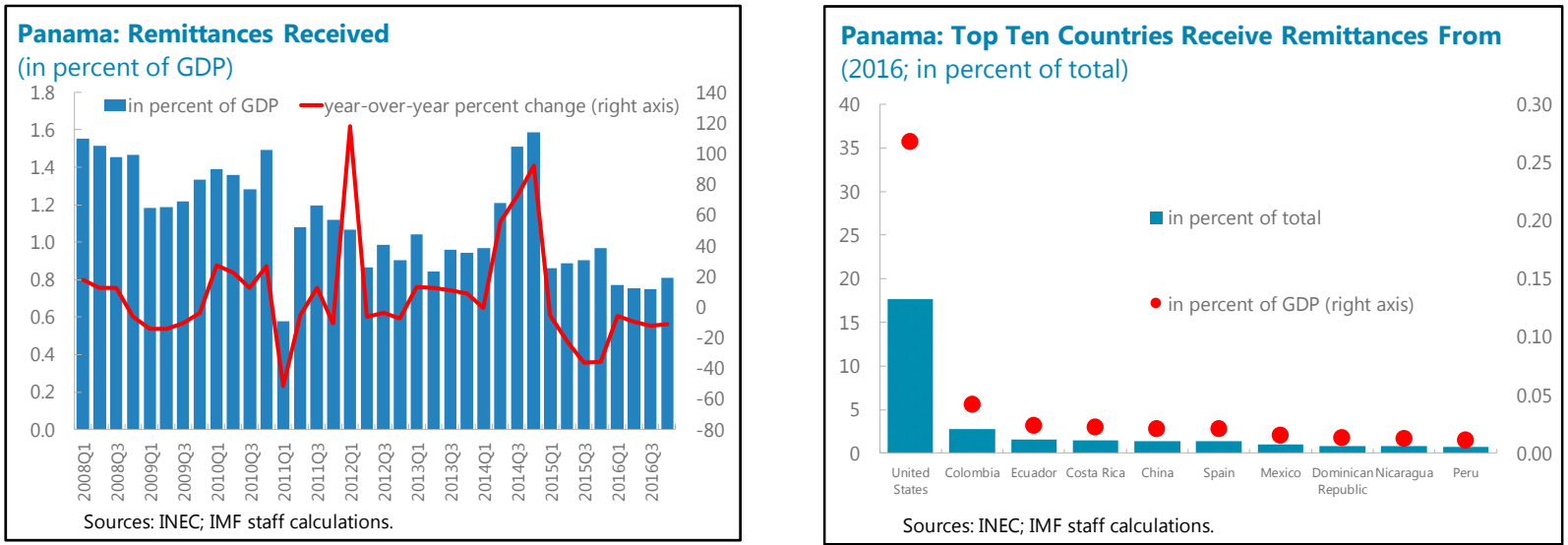

\section{Financial}

7. Panama is an important regional banking center. Financial sector assets are sizeable at 238 percent of GDP as of end-2016. Banks dominate the system, representing about 90 percent of assets, with offshore banks holding about 16 percent of bank assets. Offshore banks are prohibited from accepting deposits and extending credit locally, but do participate in the interbank market. Insurers (2 percent of financial system assets) and broker-dealers (1.8 percent of financial system assets) are the next largest segments of the financial system with the remainder of financial system assets accounted for by credit unions ( 1.5 percent) and other smaller financial institutions (see Selected Issues Paper III). In this context, Panama's financial system is primarily affected by international developments through its regional banking system.

\section{Panama's regional banking center is closely tied to Latin America, particularly} Colombia, reflecting a strong presence of Latin American banks in Panama. Of the 55 onshore banks, only 20 are Panamanian (representing 53 percent of banking system assets), with 35 foreign banks operating in Panama. ${ }^{4}$ Foreign banks operating in Panama originate primarily from Latin America. Colombian banks, in particular, have an important presence in Panama: 4 of the top 15 banks by asset size in Panama are Colombian and these banks alone represent about 17 percent of onshore banks' assets.

9. Reliance on foreign funding has increased. Since 2010, the share of onshore banks' funding accounted for by foreign sources has risen from about 30 percent to 35 percent (as of December 2016). While the share of foreign deposits in total deposits has remained relatively stable, the increase has been almost entirely due to an increase in banks' external borrowing, consistent with the low cost of external funds over this period. While banks continue to rely primarily on deposits as a source of funding, with deposits representing about three quarters of banks' total liabilities, banks' increased reliance on external borrowing as a funding source has increased banks' exposure to developments in global interest rates. While there is no data available on the distribution of banks' external borrowing by country, foreign deposits in banks, at about 23 percent

\footnotetext{
${ }^{4}$ Of the 20 Panamanian banks, two are state-owned (accounting for about 14 percent of onshore bank assets).
} 
of banks' total liabilities, are primarily from Latin America. Deposits from Venezuela, Ecuador, Costa Rica, and Colombia are particularly important, combined representing about 40 percent of foreign deposits in the Panamanian onshore banking system. Deposits from other Latin American countries represent a further 18 percent of foreign deposits.

10. Onshore banks' foreign assets are primarily concentrated in Latin America. Banks' foreign assets as a share of total (net) assets decreased from about 45 percent at the beginning of 2010 to about 38 percent at end-2016, which has somewhat reduced their exposure to external developments. These assets are composed primarily of foreign lending (43 percent of net foreign assets as of end-2016), banks' interbank deposits abroad (33 percent of foreign banks' net foreign assets) and banks' foreign investment (24 percent of banks' net foreign assets). Foreign lending is mainly to Latin America with the distribution similar to that of banks' foreign deposit base. Similarly, banks' foreign investments are also concentrated within the region with an important exposure also to the United States.

\section{Panama's offshore financial center is an important segment of Panama's regional} banking center. As of end-2016, the sector consistent of 27 banks. Given the restrictions placed on the onshore banking operations of these banks, they are almost fully funded and conduct all their lending operations abroad. About 0.6 percent of their total liabilities and 1.3 percent of their assets are held in Panama, primarily due to their limited participation in the interbank market. As with Panama's sizeable onshore sector, the offshore sector primarily serves regional customers in Latin America with the majority of banks' deposits, their primary funding source, and lending to the region.

12. Broker-dealers also conduct important cross-border business. While broker-dealers account for a much smaller share of the financial system than banks, they also have important crossborder exposures. Of the 91 brokerage houses licensed in Panama, 26 are either banks with brokerage licenses or subsidiaries of banks while the remainder are independent. Only 33 percent of the capital base of brokerage houses is Panamanian, reflecting the importance of their international clientele. Only about 6 percent of brokerage houses transactions are conducted within Panama. 
Figure 2: External Linkages of Panama's Regional Banking Center

Panama: Top 15 Banks by Asset Side: Country of Ownership 1/ (2016Q4; in percent of total assets of top 15 banks by asset size)

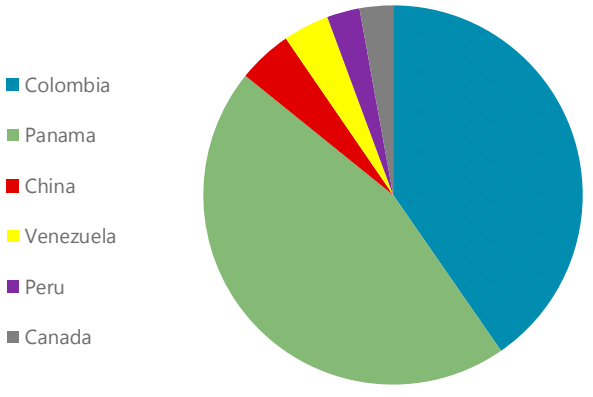

Sources: SBP; IMF staff calculations. Includes consolidated operations of subsidiaries.

National Banking System: Foreign Credit by Country (share of total foreign credit)

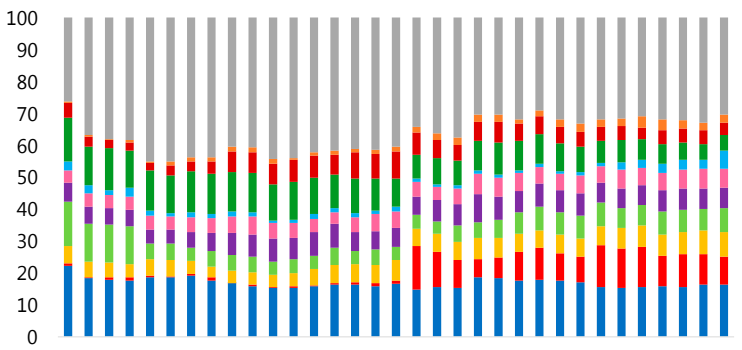

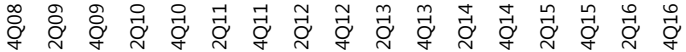
$\backsim$ CRI $\backsim \mathrm{CHN} \backsim \mathrm{GTM} \backsim \mathrm{MEX} \backsim \mathrm{COL} \backsim \mathrm{ECU} \backsim \mathrm{USA} \backsim \mathrm{BRA} \backsim \mathrm{PER} \backsim \mathrm{DOM} \backsim$ Others Source: SBP and Fund staff calculations.

International Banks: Foreign Deposits by Country

(percent of total foreign deposits)

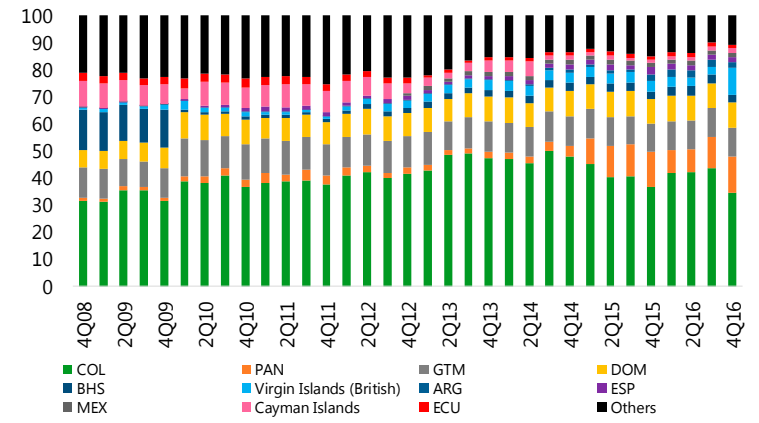

Source: SBP and Fund staff calculations.
National Banking System: Foreign Deposits by Country (percent of total foreign deposits)

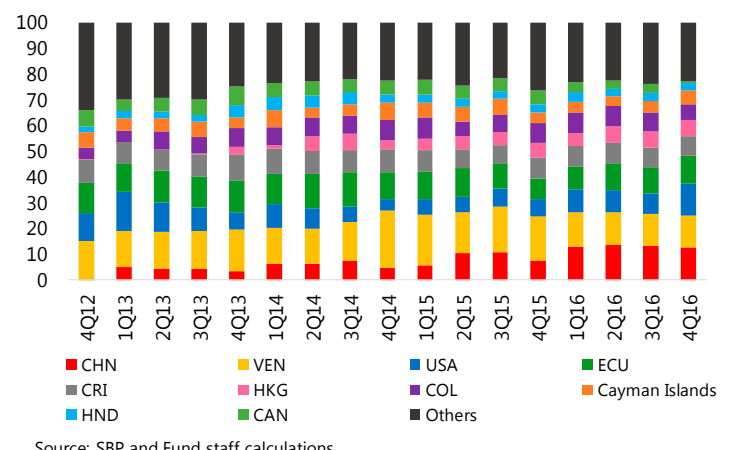

Source: SBP and Fund staff calculations.

National Banking System: Investments Abroad by Country 2015 (share of total investments abroad)

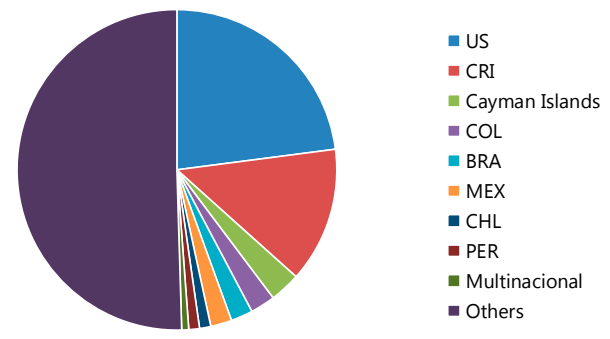

Sources: SBP and Fund staff calculations.

International Banking: Foreign Credit by Country (share of total foreign credit)

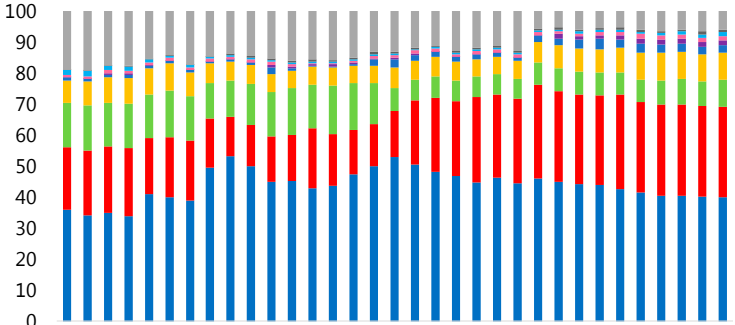

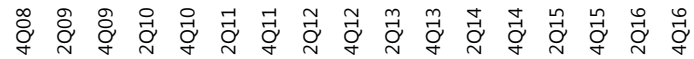
$\because \mathrm{PER}\|\mathrm{COL} \backsim \mathrm{GTM}\| \mathrm{DOM}\|\mathrm{SLV} \backsim \mathrm{PAN} \backsim \mathrm{ECU}\| \mathrm{CRI} \| \mathrm{MEX} \backsim$ Others 


\section{B. Spillovers from the U.S. and the Region}

External linkages through trade, FDI flows, and the financial system expose Panama's economy to spillovers from abroad. This section examines the importance of such spillovers from the U.S. and countries in the region. First, it looks at the importance of real linkages through several correlations between growth rates in these economies and Panama. Second, it presents regression results that identify the most important external factors for Panama's (sectoral) economic growth. Third, it provides estimates on spillovers from foreign interest rates and the exchange rate.

\section{Economic fluctuations in other countries have significant impact Panama's economic} activity. Output growth in Panama is strongly correlated with output growth in partner economies (text figure and Table 1). Moreover, pattern of correlation of Panama's business cycle with partners' countries', suggests that business cycles in regional partners and the U.S. typically lead Panama's business cycle. This finding is captured by the downward sloping correlations and suggests that growth developments in Panama are driven to a large extent by economic fluctuations abroad.

\section{Panama's economic activity displays} especially strong correlation with the Colombian economy. Consistent with Panama's important trade and FDI connections, as well as the considerable presence of Colombian institutions in the banking sector, the comovement of Panama's growth with Colombia's is significantly stronger than with other countries. Colombia's impact on Panama's growth appears to be much stronger than the impact of the U.S. economy, which represents a key trade partner and source of FDI for Panama.

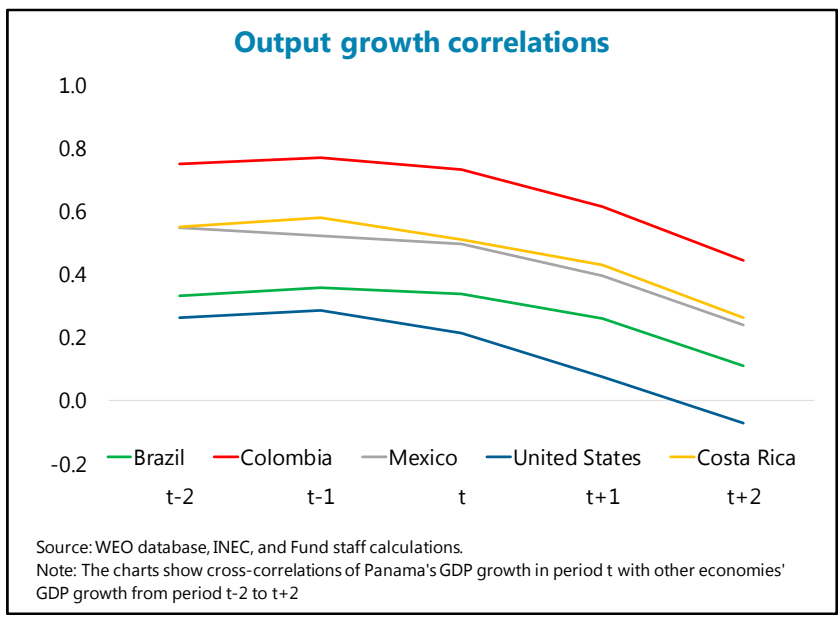

Table 1: Business Cycle Comovement of Panama with Other Economies

Business Cycle Comovement of Panama with Other Economies (2000Q1-2016Q2) Cross-correlations of Panama's GDP growth in period t with other economies' GDP growth from period $\mathrm{t}-2$ to $\mathrm{t}+2$

\begin{tabular}{|c|c|c|c|c|c|}
\hline & Brazil & Colombia & Mexico & United States & Costa Rica \\
\hline$t-2$ & 0.33 & 0.75 & 0.55 & 0.26 & 0.55 \\
\hline$t-1$ & 0.36 & 0.77 & 0.52 & 0.28 & 0.58 \\
\hline $\mathbf{t}$ & 0.34 & 0.73 & 0.50 & 0.21 & 0.51 \\
\hline$t+1$ & 0.26 & 0.61 & 0.40 & 0.08 & 0.43 \\
\hline$t+2$ & 0.11 & 0.44 & 0.24 & -0.07 & 0.26 \\
\hline
\end{tabular}

15. Panama's stronger comovement with Colombia may partly capture the impact from the U.S. The comovement of Panama's growth with Colombia's appears to be stronger both in times of expansion as well as in times of economic slowdown. To some extent, these findings may 
reflect the fact that the Colombian economy already captures part of the impact of U.S. growth shocks on Panama. Similarly, some global shocks may be transmitted through the Colombian economy.
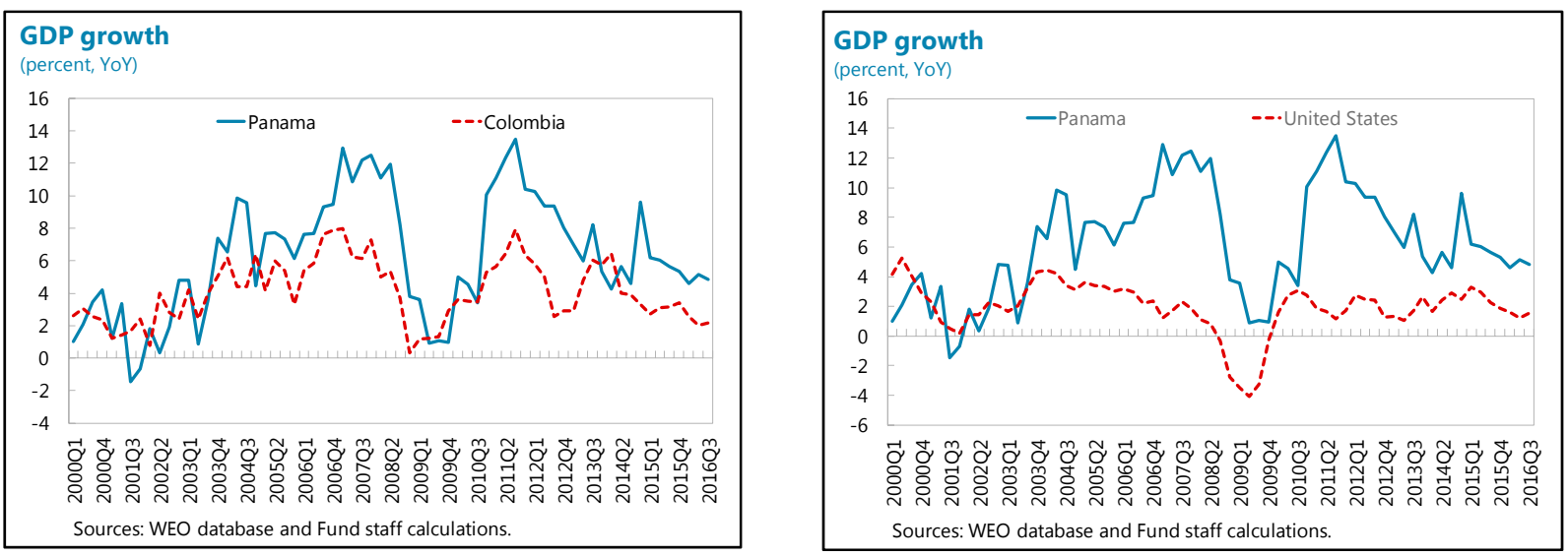

16. The services sector appears to be more exposed to external spillovers than other sectors The relative importance of services trade for Panama gets reflected in the services sector's stronger comovement with partner economies compared to industry and construction (text figure). Spillovers from the U.S. economy are significantly more important for the services sector than for other sectors of the economy, which is consistent with the earlier-documented importance of the U.S. for Panama's service exports, and particularly for Canal activity.

\section{Spillovers from Colombia are stronger than spillovers from other countries for all} three broad sectors of the Panamanian economy. In line with the findings for the overall economy, the correlation coefficients (text figure) suggest that Colombia's dominance is not limited to specific sector of economic activity. In addition, growth fluctuations in Colombia generally seem to precede movements in Panama's industry and construction, while the contemporaneous impact seems to be the strongest for the services sector. 
Figure 3: Co-movement of Sectoral Economic Activity in Panama with Key Countries

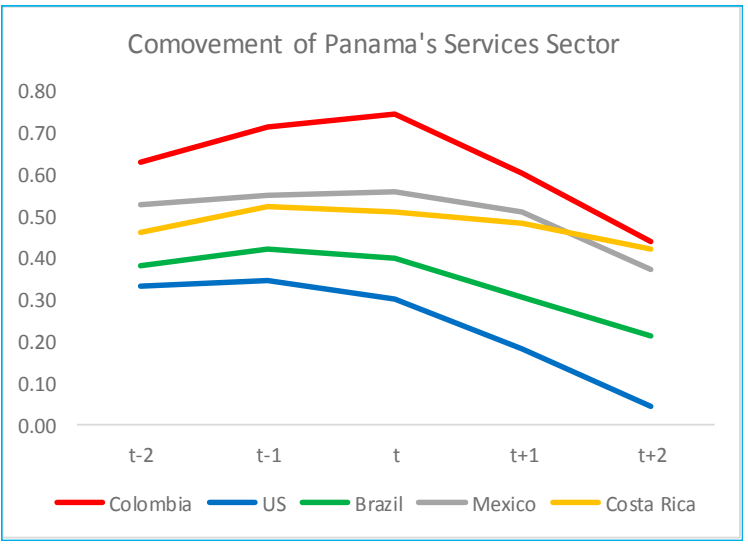

$\begin{aligned} & \text { Cross-correlations of Panama's service sector growth in period t with } \\
& \text { other economies' GDP growth from period t-2 to t+2 }(2000 \mathrm{Q} 1-2016 \mathrm{Q} 3)\end{aligned}$
\begin{tabular}{|l|rrrrrr|}
\hline Services & Colombia & US & Brazil & Mexico & Costa Rica \\
\hline $\mathbf{t}-\mathbf{2}$ & 0.63 & 0.34 & 0.38 & 0.53 & 0.46 \\
$\mathbf{t}-1$ & 0.71 & 0.35 & 0.42 & 0.55 & 0.52 \\
$\mathbf{t}$ & 0.74 & 0.30 & 0.40 & 0.56 & 0.51 \\
$\mathbf{t}+\mathbf{1}$ & 0.60 & 0.18 & 0.31 & 0.51 & 0.48 \\
$\mathbf{t}+\mathbf{2}$ & 0.44 & 0.04 & 0.21 & 0.37 & 0.42 \\
\hline
\end{tabular}

Source: WEO database, INEC, and Fund staff calculations

Comovement of Panama's Industry Sector

0.70

0.60

0.40

0.30

0.20

0.10

0.00

$-0.10$

$-0.20$

$-0.30$

Colombia $\longrightarrow$ US $\longrightarrow$ Brazil $\longrightarrow$ Mexico Costa Rica

Comovement of Panama's Construction Sector

0.50

0.40

0.30

0.20

0.10

0.00

$-0.10$

$-0.20$

Colombia $\longrightarrow$ US $\longrightarrow$ Brazil $\longrightarrow$ Mexico Costa Rica

Source: WEO database, INEC and Fund staff calculations.
Cross-correlations of Panama's industry sector growth in period t with other economies' GDP growth from period t-2 to $t+2$ (2000Q1-2016Q3)

\begin{tabular}{|l|rrrrr|}
\hline Industry & Colombia & US & Brazil & Mexico & Costa Rica \\
\hline $\mathbf{t}-\mathbf{2}$ & 0.59 & -0.13 & 0.13 & 0.16 & 0.24 \\
$\mathbf{t}-\mathbf{1}$ & 0.53 & -0.07 & 0.14 & 0.19 & 0.20 \\
$\mathbf{t}$ & 0.42 & -0.09 & 0.12 & 0.20 & 0.17 \\
$\mathbf{t + 1}$ & 0.30 & -0.20 & 0.09 & 0.13 & 0.08 \\
$\mathbf{t + 2}$ & 0.22 & -0.23 & 0.00 & 0.08 & -0.03 \\
\hline
\end{tabular}

Source: WEO database, INEC, and Fund staff calculations
Cross-correlations of Panama's construction sector growth in period $t$ with other economies' GDP growth from period t-2 to t+2 (2000Q1-2016Q3)

\begin{tabular}{|l|rrrrr|}
\hline Construction & Colombia & \multicolumn{1}{l}{ US } & Brazil & Mexico & Costa Rica \\
\hline $\mathbf{t}-\mathbf{2}$ & 0.37 & 0.08 & 0.15 & 0.23 & 0.35 \\
$\mathbf{t}-\mathbf{1}$ & 0.38 & 0.07 & 0.14 & 0.24 & 0.31 \\
$\mathbf{t}$ & 0.32 & 0.03 & 0.12 & 0.21 & 0.15 \\
$\mathbf{t}+\mathbf{1}$ & 0.31 & -0.03 & 0.11 & 0.10 & 0.04 \\
$\mathbf{t}+\mathbf{2}$ & 0.32 & -0.11 & 0.07 & 0.01 & -0.11 \\
\hline
\end{tabular}

Source: WEO database, INEC, and Fund staff calculations 


\section{What External Factors Explain Panama's Growth?}

18. Colombia's growth explains about two thirds of Panama's growth fluctuations. We investigate the impact of external factors on Panama's growth using regression analysis and the results suggest that Colombia's growth is the dominant explanatory factor (Table 2). In addition, Colombia's growth seems to have an amplifying effect on Panama, with an estimated elasticity of about $1 \frac{1}{2}$.

Other factors that affect Panama's growth include oil prices, global uncertainty measured by the VIX, and U.S. policy interest rates. U.S. growth is also an important factor, albeit it loses significance once Colombia's growth is included in the estimations, suggesting that Colombia captures

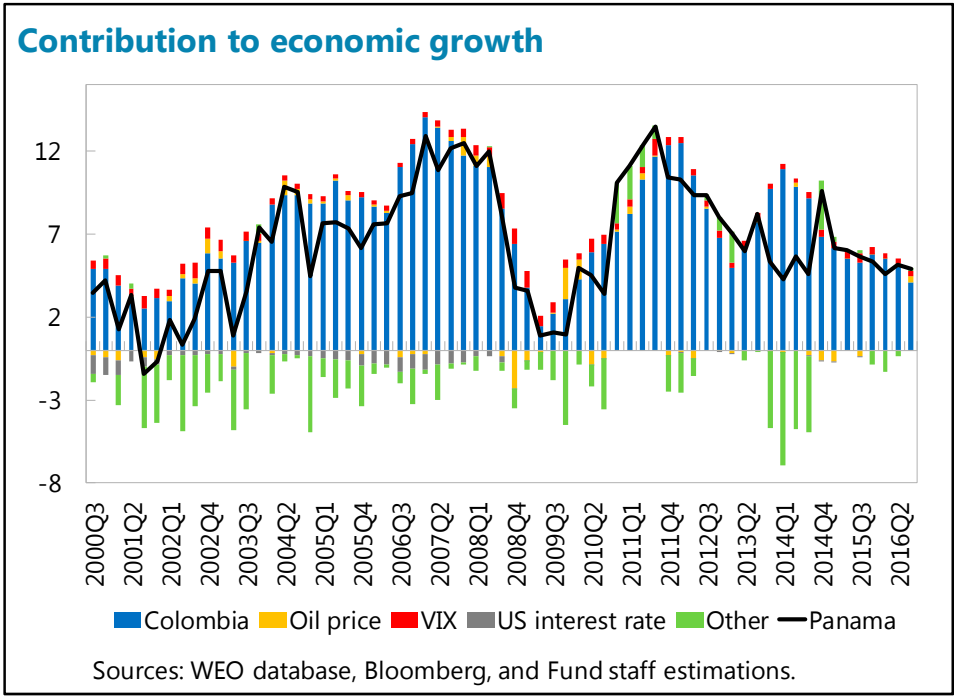
(partly) the effect of U.S. growth.

\begin{tabular}{|c|c|}
\hline \multicolumn{2}{|c|}{$\begin{array}{l}\text { Table 2: Regression Results: Impact o } \\
\text { External Factors of Panama's Growth }\end{array}$} \\
\hline & panama \\
\hline \multirow[t]{2}{*}{ Colombia growth } & $0.479 * *$ \\
\hline & $(0.0347)$ \\
\hline \multirow[t]{2}{*}{ Colombia growth (lagged) } & $0.509 *$ \\
\hline & $(0.0508)$ \\
\hline \multirow[t]{2}{*}{ Colombia growth (second lag) } & $0.816^{* * *}$ \\
\hline & $(0.000246)$ \\
\hline \multirow[t]{2}{*}{ Oil prices } & $0.0266 *$ \\
\hline & $(0.0510)$ \\
\hline \multirow[t]{2}{*}{ Oil prices (lagged) } & $-0.0232 *$ \\
\hline & $(0.0952)$ \\
\hline \multirow[t]{2}{*}{ VIX } & 0.0233 \\
\hline & $(0.519)$ \\
\hline \multirow[t]{2}{*}{ US Interest rates } & -0.169 \\
\hline & $(0.236)$ \\
\hline \multirow[t]{2}{*}{ Constant } & -1.261 \\
\hline & $(0.319)$ \\
\hline Observations & 65 \\
\hline R-squared & 0.723 \\
\hline \multicolumn{2}{|l|}{ pval in parentheses } \\
\hline \multicolumn{2}{|l|}{$* * * p<0.01, * * p<0.05, * p<0.1$} \\
\hline
\end{tabular}




\section{Colombia's growth performance is a dominant factor for different sectors in the} Panamanian economy. In particular, Colombia's growth accounts for about two thirds of fluctuations in the services sector. To some extent, this effect captures other common factors, including U.S. growth, which turns insignificant when included in the same specification. Colombia's growth remains the most important explanatory factor for industry and construction as well, though less so than in the case of services. ${ }^{5}$ In this context, interest rates in the U.S. seem to explain some parts of the variability in industry and construction in the period before the global financial crisis, while their impact on the services sector appears negligible.

\footnotetext{
${ }^{5}$ This is consistent with the evidence that construction and manufacturing are typically found to be more sensitive to interest rate changes because the demand for their products as well as their inputs in production rely relatively more on credit. For example, see Carlino and DeFina (1998) and Carlino and DeFina (1999) on the importance of the industry mix for the differential impact of monetary policy.
} 
Figure 4: Impact of External Factors on Sectoral Growth in Panama

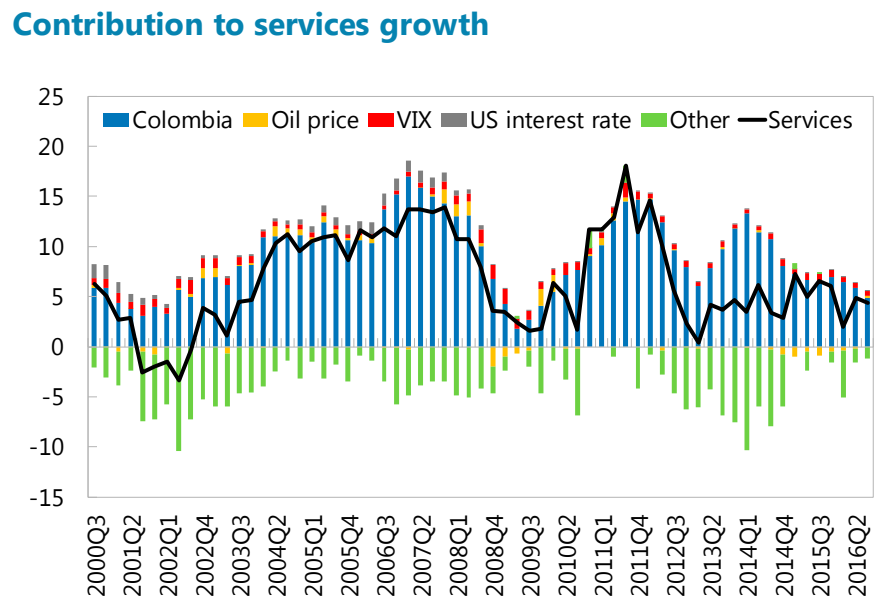

Contribution to industry growth

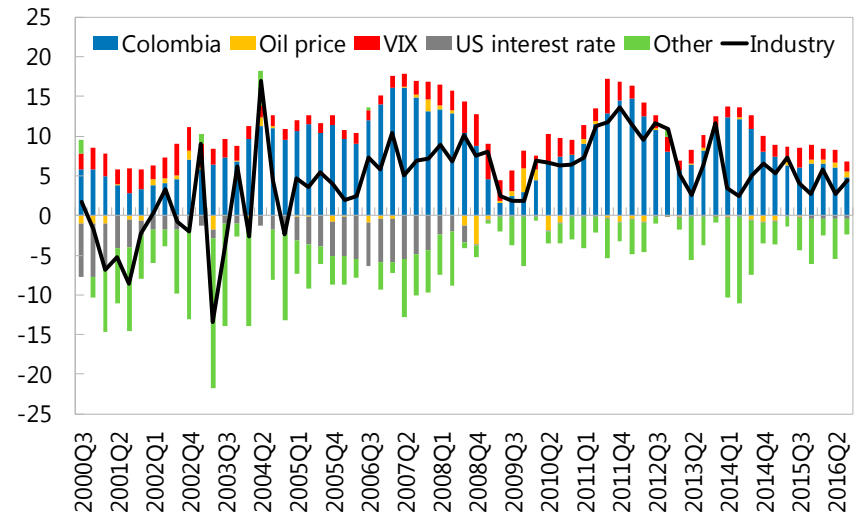

Contribution to construction sector growth

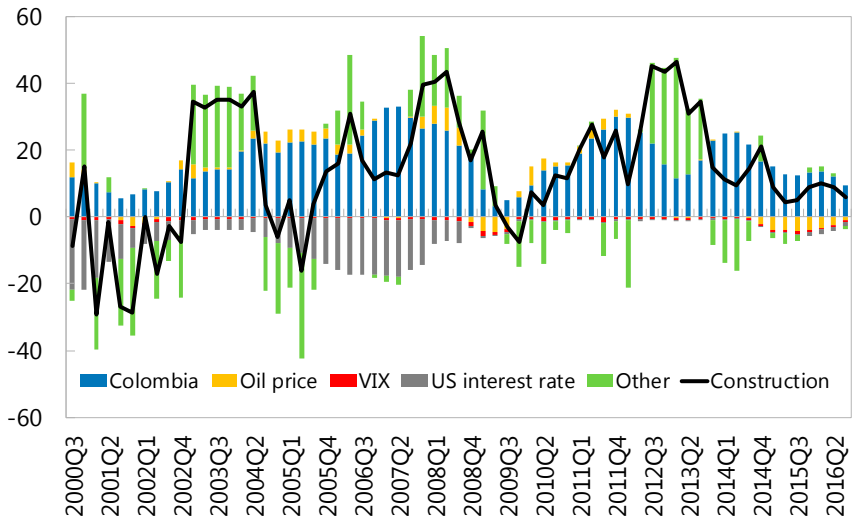

Source: WEO database, IFS, Bloomberg, INEC, and Fund staff estimations. 
20. The services sector appears to be more sensitive to U.S. growth fluctuations than other sectors. U.S. growth is related to the performance of Panama's services sector to a certain degree, though this relationship is not very strong. ${ }^{6}$ This is consistent with the key importance of the U.S. economy for Panama's services exports. In particular, Canal traffic to/from destinations in the U.S. is significantly higher than traffic to/from any other country. Besides this direct effect, a positive shock to the U.S. economy contributes indirectly through higher regional and global growth, which result in more trade and Canal activity, as well as higher demand for logistics and related services.

\section{Industry and construction in Panama do not seem to be affected by U.S. economic} growth. In line with the weak linkages through goods trade described in earlier sections, industry fluctuations do show any noticeable relationship with U.S. growth. Similarly, as noted earlier, construction is more related to economic activity in the immediate region, particularly Colombia, than the U.S. Overall, the U.S. seems to affect these sectors only indirectly through the interest rate channel.

\section{Spillovers through Interest Rates and Exchange Rates}

22. Lending interest rates in Panama have been very stable over the past several years. Their trend appears to have been isolated from the rising interest rates in the U.S. and countries in the region in the mid-2000s, but also from the significant decline in interest rates during the initial phase of the global financial crisis. With ample liquidity buffers and primarily relying on domestic deposits for funding, Panamanian banks could isolate their lending rates from global interest rate trends.

\section{Colombian lending rates had a stronger} impact than U.S. rates on Panamanian lending rates. Estimation results in Table 3 suggest that interest rate developments in both Colombia and the U.S. affected Panamanian lending rates. However, when included jointly, the effect of Colombian rates dominates, a finding that seems surprising in light of Panama's full dollarization. In addition, these estimations suggest that an increase in Colombia's lending rates by one percentage point is associated with an increase in Panama's rates of about 30 basis points, roughly three times larger than the impact from U.S. rates. Colombian rates remain dominant when a time trend is included in the specification, though their impact is reduced by about a half.

\footnotetext{
${ }^{6}$ Regression results suggest that the impact of U.S. economic growth is statistically significant for Panama's services sector and not significant for the other sectors.
} 
Figure 5: Impact of U.S. Growth on Sectoral Growth in Panama
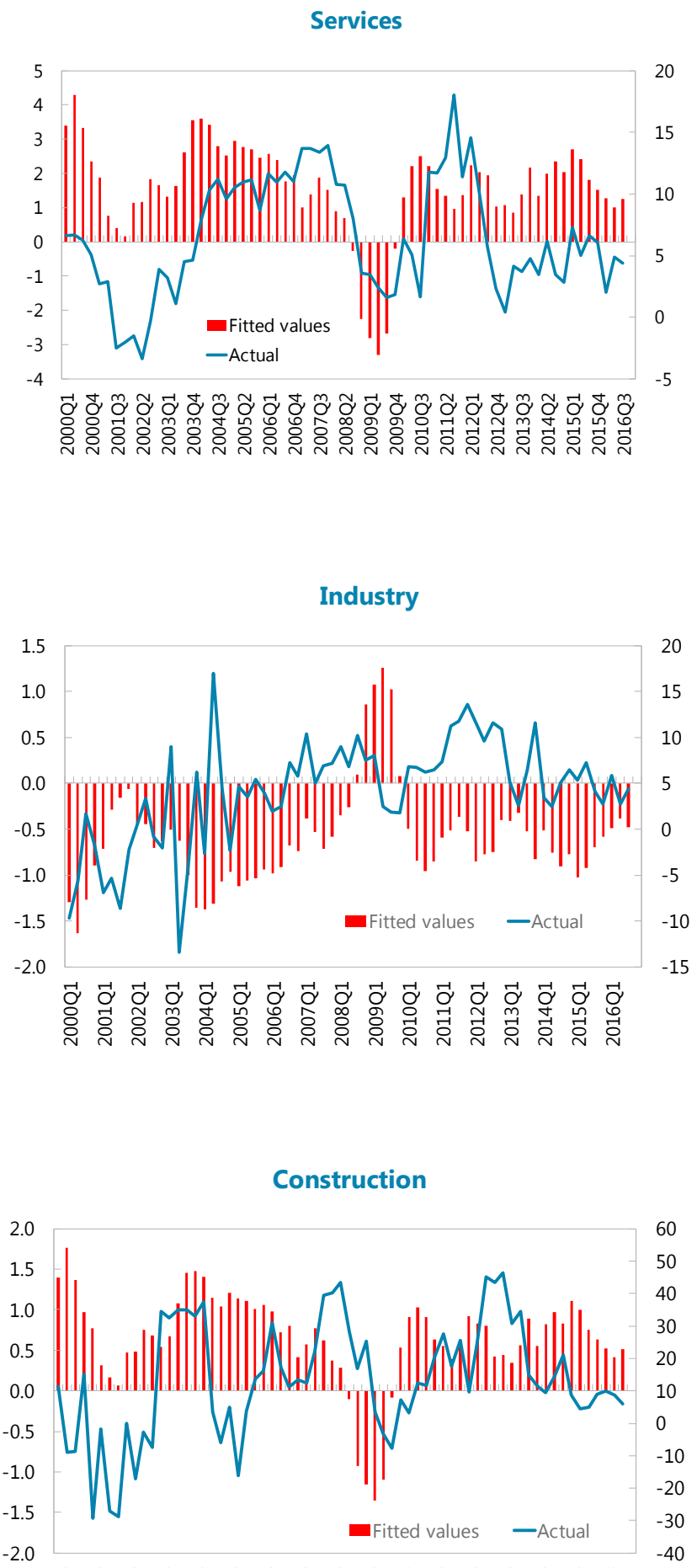

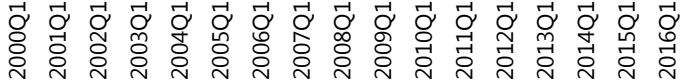

Source: WEO database, IFS, Bloomberg, INEC, and Fund staff estimations. 


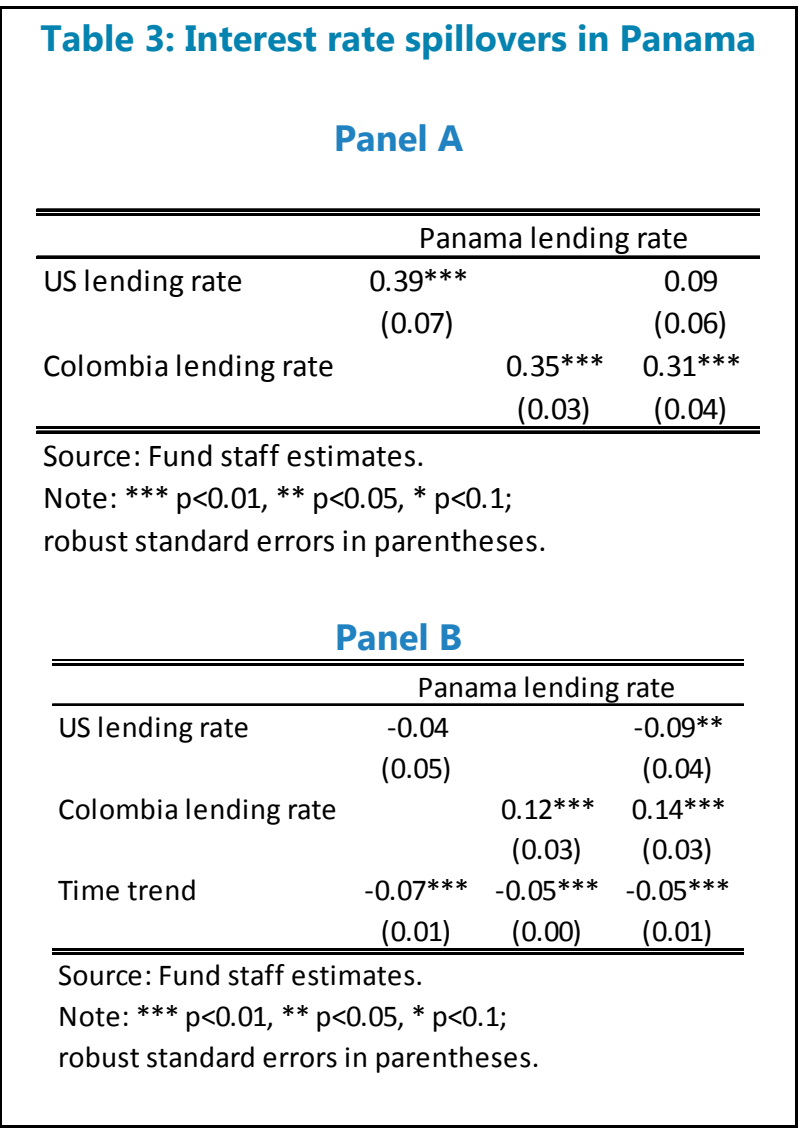

\section{Given dollarization, changes in the value U.S. can directly affect external}

competitiveness. For instance, dollar appreciation relative to the currencies of Panama's important trading partners, would put pressures on the real effective exchange rate, and in turn, would expose Panama to the risk of losing external competitiveness. The relevance of such a scenario critically depends on the sensitivity of exports to REER fluctuations.

\section{Exchange rate changes affect goods exports, but do not have a significant impact on} overall services exports. Estimations results in Table 4 show that REER appreciation has a significantly negative impact on goods exports as well as on re-exports from the Colon Free Zone. ${ }^{7}$ In contrast, REER fluctuations do not have a significant impact on Panama's overall service exports, a finding that differs from empirical studies that detect a stronger impact of the REER on service exports than on goods imports for a global sample of countries (Eichengreen and Gupta, 2013).

\section{The weaker effect found for Panama may reflect the large heterogeneity of economic activities included in Panama's services exports portfolio, which may have significantly different levels of sensitivity to the exchange rate. On one hand, services related to the Canal}

\footnotetext{
7 This effect is slightly stronger when Venezuela is excluded from the calculation of the REER. Venezuela is excluded to avoid distortions of the REER as a result of the exceptionally high domestic inflation in Venezuela in recent years.
} 
and the cluster gravitating around it may have low exchange rate sensitivity as there are limited alternatives for global transport that are isolated from the U.S. dollar exchange rate fluctuations. On the other hand, services such as tourism are likely to be more exchange rate-sensitive. Hence, the overall sensitivity of Panama's export services to REER fluctuations would reflect the relative importance of these groups of services. If the tourism sector picks up faster than logistics services in the future, Panama's overall exports are likely to become more exchange-rate sensitive.

\begin{tabular}{|c|c|c|c|}
\hline & Goods exports & CFZ re-exports & Services exports \\
\hline \multirow[t]{2}{*}{ REER } & $-1.52^{* *}$ & $-1.87^{* *}$ & 0.15 \\
\hline & $(0.75)$ & $(0.84)$ & $(0.40)$ \\
\hline \multirow[t]{2}{*}{ REER (ex Venezuela) } & $-2.31^{* *}$ & $-2.10^{* *}$ & 0.04 \\
\hline & $(0.73)$ & (0.93) & $(0.42)$ \\
\hline
\end{tabular}

Source: Fund staff estimates.

\section{Conclusions}

\section{Panama is a small and open economy with a high level of integration into the} international trade and finance network. External linkages through trade, FDI flows, and the financial system expose Panama's economy to spillovers from abroad. Economic developments in partner economies are found to have an important impact on Panama's economic performance. In particular, Colombia produces strong economic spillovers to Panama, which are significantly more important than spillovers from the U.S. economy. In addition, Colombian growth is found to be a key factor explaining Panama's economic growth. Panama is also exposed to financial spillovers, with its lending rates being more sensitive to Colombian than U.S. lending rates. Given dollarization, Panama's exchange rate appreciates with a stronger U.S. dollar. Nonetheless, appreciation is found to have a stronger impact on goods exports than on overall services, Panama's key export category. 


\section{References}

Carlino, G. and R. DeFina (1998), "The Differential Regional Effects of Monetary Policy", Review of Economics and Statistics, 80 (4), pp.572-587.

Carlino, G. and R. Defina (1999), "The Differential Regional Effects of Monetary Policy: Evidence from the U.S. States", Journal of Regional Science, 39 (2), pp.339-358.

Eichengreen, B. and P. Gupta (2013), "The Real Exchange Rate and Export Growth: Are Services Different?", World Bank Policy Research Working Paper 6629.

Ghemawat, P., and St. Altman (2014). "DHL Global Connectedness Index 2014," Deutsche Post DHL, November 2014 


\section{SAFEGUARDING FINANCIAL STABILITY IN PANAMA: A FRAMEWORK FOR SYSTEMIC RISK OVERSIGHT AND MACROPRUDENTIAL POLICY ${ }^{1}$}

This paper assesses potential sources of systemic risk in the Panamanian financial system and recommends a framework for systemic risk oversight and macroprudential policy in Panama. To complement the recommended framework, policies to strengthen the crisis management framework are also considered.

\section{A. Introduction}

1. This chapter proposes a framework for systemic risk oversight and macroprudential policy in Panama. To set the context for the proposed framework, the structure of Panama's financial system and its oversight are first reviewed. Elements of a framework for systemic risk oversight and macroprudential policy are then proposed, taking into consideration the unique structure of the Panamanian financial system and its oversight. Namely, the chapter proposes a framework for systemic risk oversight and macroprudential policy based on three pillars: i) an institutional arrangement, ii) systemic risk oversight, iii) macroprudential policy tools. To complement the recommended framework for systemic risk oversight and macroprudential policy, policies to strengthen the crisis management framework are then considered.

\section{B. Structure of Panama's Financial System and its Oversight}

2. Panama is an important regional financial center. Total financial system assets represent more than 2 times GDP (Table 1). The financial system is the largest in Latin America and is dominated by banks, which represent about 92 percent of total system assets. The banking center encompasses a sizable offshore sector (including 28 banks accounting for 16.5 percent of total banking system assets), with limited connections to the domestic financial system (Table 2). ${ }^{2}$ Foreign banks have a strong presence in Panama: of the 55 onshore banks, 35 are foreign (representing about 47 percent of onshore banking system assets). Foreign banks originate primarily from Latin America, although a few international banking groups manage their Latin American operations from and sub-consolidate their regional activity in Panama. Several of Central America's largest regional financial conglomerates also consolidate their banking activity in Panama, although the majority of their assets are located in the country of origin. Banks are closely intertwined with other segments of the financial system through their insurance and broker-dealer subsidiaries.

\footnotetext{
${ }^{1}$ Prepared by Kimberly Beaton and Jun Kusumoto.

${ }^{2}$ Offshore banks offer a wide range of services to non-residents but are not permitted to conduct domestic transactions except for transactions on the local interbank market. Offshore banks deposits in onshore banks are limited at 0.8 percent of their total assets.
} 


\begin{tabular}{|c|c|c|c|}
\hline \multicolumn{4}{|c|}{$\begin{array}{l}\text { Table 1: Structure of Panama's Financial System } \\
\text { (2016; millions of US dollars) }\end{array}$} \\
\hline & Assets & $\%$ of Assets & $\%$ of GDP \\
\hline Banks & 121075 & 92.1 & 219.4 \\
\hline Onshore & 101152 & 77.0 & 183.3 \\
\hline Offshore & 19923 & 15.2 & 36.1 \\
\hline Securities sector & 2400 & 1.8 & 4.3 \\
\hline Insurers & 2602 & 2.0 & 4.7 \\
\hline Development banks & 607 & 0.5 & 1.1 \\
\hline Credit unions & 1956 & 1.5 & 3.5 \\
\hline Other & 2775 & 2.1 & 8.1 \\
\hline TOTAL & 131415 & 100.0 & 238.1 \\
\hline
\end{tabular}

Table 2: Overview of Panama's Regional Banking Center (end 2016; millions of US dollars unless otherwise stated)

\begin{tabular}{lcccc}
\hline & \multicolumn{2}{c}{ Onshore Banking System } & \multirow{2}{*}{ Offshore } \\
\cline { 2 - 4 } \cline { 3 - 4 } & $\begin{array}{c}\text { State- } \\
\text { owned }\end{array}$ & Foreign & Panamanian & \\
\cline { 2 - 4 } Number of banks & 2 & 35 & 18 & 27 \\
Number of employees & 4903 & 9851 & 10393 & 915 \\
Total Assets & 13822 & 47745 & 39586 & 19923 \\
Total loans & 5932 & 31806 & 26787 & 10385 \\
Residents & 5932 & 18213 & 23908 & 0 \\
Non-Residents & 0 & 13592 & 2879 & 10385 \\
Total Deposits & 12318 & 33967 & 27634 & 12072 \\
Residents & 12284 & 14552 & 23834 & 65 \\
Non-Residents & 34 & 19415 & 3800 & 12007 \\
NPL / Total Loan (\%) & 2.38 & 2.39 & 1.62 & 0.82 \\
ROA (\%) & 1.62 & 2.64 & 2.02 & 2.13 \\
CAR (\%) & 14.23 & 14.26 & 16.25 & 21.15 \\
\hline
\end{tabular}

Source: SBP; Fund staff calculations.

\section{The onshore banking system maintains a traditional model of lending financed} primarily with deposits. Retail deposits account for about three-quarters of banks' funding, of which about 30 percent are foreign deposits. Wholesale funding is relatively limited (16 percent of 
onshore banks' funding), but is concentrated in foreign sources (74 percent). Banks' assets are concentrated in loans (65 percent of total assets), while securities' holdings (17 percent of assets) and deposits in other banks (15 percent) account for the bulk of the remainder of banks' assets. Banks' lending portfolios are conventional, concentrated in commercial loans (24 percent), mortgages (31 percent) and consumer loans (21 percent). Credit unions also provide financial intermediation, but play a small role compared to banks. As of end-2016, credit unions' total assets amounted to about 1.5 percent of financial sector assets. ${ }^{3}$ Their lending is primarily oriented toward consumer loans, including to fund microenterprises, and mortgages.

\section{With the strong presence of foreign banks, the Panamanian banking sector maintains} important cross-border exposures. In addition to the sector's exposure to foreign deposits, banks maintain important cross-border asset holdings. Loans to non-residents are about 17 percent of onshore banking system assets or about 29 percent of GDP, while offshore banks' loans to nonresidents account for a further 18 percent of GDP. Over half (55 percent) of the securities in banks' portfolios are external and banks' deposits in foreign banks represent over three-quarters of their interbank deposits, as many foreign onshore banks hold deposits at their parent banks or other banks abroad, including their foreign correspondent banks. ${ }^{4}$

\section{Insurers are a growing segment of Panama's financial system. The sector's assets} account for about 4.7 percent of GDP, with total premiums amounting to about 2.5 percent of GDP. ${ }^{5}$ Life, health, and automobile insurance account for just under 65 percent of premiums. Use of nontraditional insurance products remains limited. As previously highlighted, many insurers are part of large financial conglomerates with many banks having insurance arms or subsidiaries, some of which are listed on the Panamanian stock exchange. Insurers are also directly connected to the banking system, with some insurers borrowing from onshore banks to finance their investment portfolios, and others holding deposits in the banking system.

6. The domestic capital market is small. Total assets of all firms operating in the securities sector are equivalent to just over 4 percent of GDP. Capital market intermediaries primarily serve international clients with relatively small domestic operations. There are 91 brokerage houses licensed in Panama, of these 26 are either banks with brokerage licenses or subsidiaries of banks. Brokerage houses primarily manage portfolios for non-residents: only about 6 percent of transactions are conducted within Panama.

\section{The responsibility for financial sector oversight is decentralized. Responsibility for} financial sector oversight falls under eight separate entities (see text figure). To enhance coordination in the decentralized oversight framework, the Financial Coordination Council (FCC) was established in 2011 and consists of six of the financial sector supervisors, Membership includes (i)

\footnotetext{
${ }^{3}$ Two small development banks, Banco de Desarollo Agropecuario (BDA) and Banco Hipotecario Nacional (BHN), grant medium-and long term credits to the rural sector and mortgage loans to low-income individuals respectively at subsidized rates.

${ }^{4}$ The state-owned Banco Nacional de Panamá accounts for 26 percent of onshore banks' foreign deposits.

${ }^{5}$ Over 97 percent of premiums are local.
} 
Superintendency of Banks (SBP), (ii) the Superintendency of the Securities Market (SMV) (iii) the Superintendency of Insurance and Reinsurance of Panama (SSRP), (iv) Panamanian Autonomous Cooperative Institute (IPACOOP) (v) System of Savings and Capitalization of Pensions of Public Servants (SIACAP), and (vi) Ministry of Commerce and Industries (MICI), with the SBP serving as the permanent chair.. The Banco Hipotecario Nacional (BHN), which regulates and supervises savings and loans associations and the Office of the Comptroller, which overseas development banks, are not included in the FCC, although the institutions they oversea represent a relatively small share of total financial system assets.

\section{The FCC is an important forum for information exchange across financial sector}

supervisors. The FCC was primarily established to strengthen supervision and coordinate regulation across supervisors in support of effective supervision of the entire financial sector. The FCC does not have an explicit mandate for systemic risk oversight, although one of its objectives is to enhance confidence in the financial sector.

\section{Figure 1: Panama: Financial Sector Oversight}

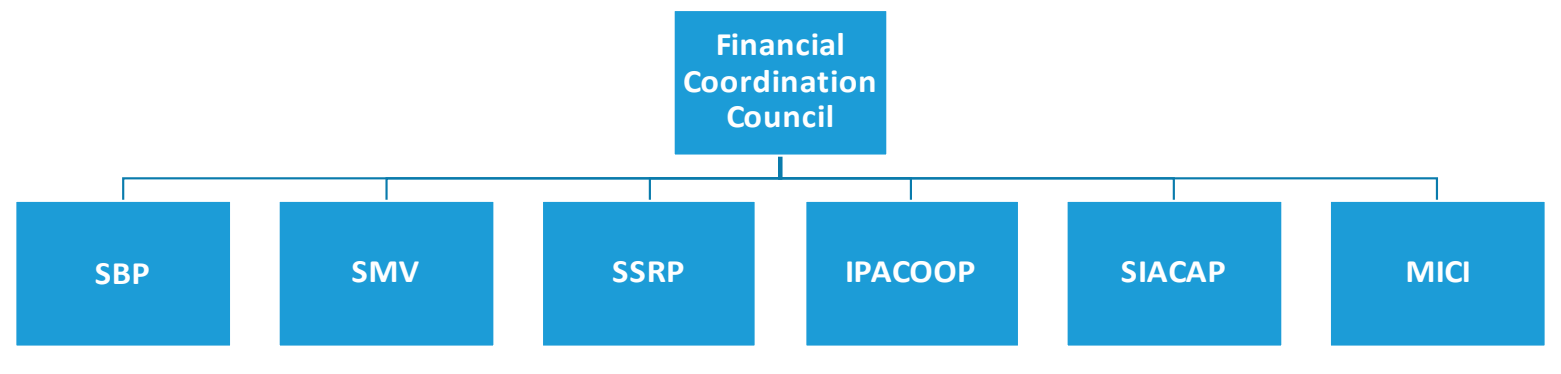

\section{Financial Sector Developments}

\section{Credit growth has been robust, but the credit cycle appears to be at a turning point.}

Panama has experienced a prolonged expansion of credit, which in recent years has outpaced the growth of deposits. However, more recently, the cost of funding has risen. Banks have responded by raising lending rates and tightening credit supply to realign its expansion with the deposit base. Credit demand has slowed simultaneously, linked to the moderation in economic activity, and consequently credit growth has started to decelerate from the high rates of the past few years. Nevertheless, the credit-to-GDP ratio is elevated at 96 percent of GDP at end-2016. The credit-toGDP gap, which assesses the increase in the credit-to-GDP ratio relative to its trend, suggests that the ratio has recently evolved in line with its trend. However, in the Panamanian context, the gap may not fully capture overall systemic risks from rapid credit growth given that Panama has 
experienced a prolonged credit boom since 2000 when credit data became available. Thus, the calculated trend may be distorted and credit risks may be higher than suggested by the gap.

\section{Macro-financial stability risks from the prolonged credit expansion remain a concern.}

The recent deceleration in credit growth has been primarily related to banks cutting exposures to the Colon Free Zone. In contrast, household borrowing continues to fuel credit growth. The increase in household debt has been broad-based with personal loans, particularly for credit cards and automobiles showing rapid growth in addition to residential mortgages. The assessment of macrofinancial risks from the rapid increase of household credit is hindered by a lack of available data on property prices, household debt service and loan-to-value (LTV) ratios. However, anecdotal evidence suggests that property prices have risen in tandem with credit. The rapid increase of household debt, which occurred in an environment of very low interest rates, could present a significant risk if the anticipated risk in global interest rates puts pressures on Panamanian interest, particularly as borrowing is primarily on a variable rate basis. Credit risks would rise, particularly in the event of a slowdown in the domestic economy or a correction in property prices, with anecdotal evidence suggestive of oversupply in some segments of property markets. Nonetheless, these risks could be offset by banks' reportedly conservative lending practices, which have traditionally required low LTV ratios and the existing practice of automatic payroll deductions for household credit which limit debt service to 50 percent of households' income. While credit to commerce has slowed, there is no data on corporate balance sheets available to assess the build-up of related macro-financial risks.
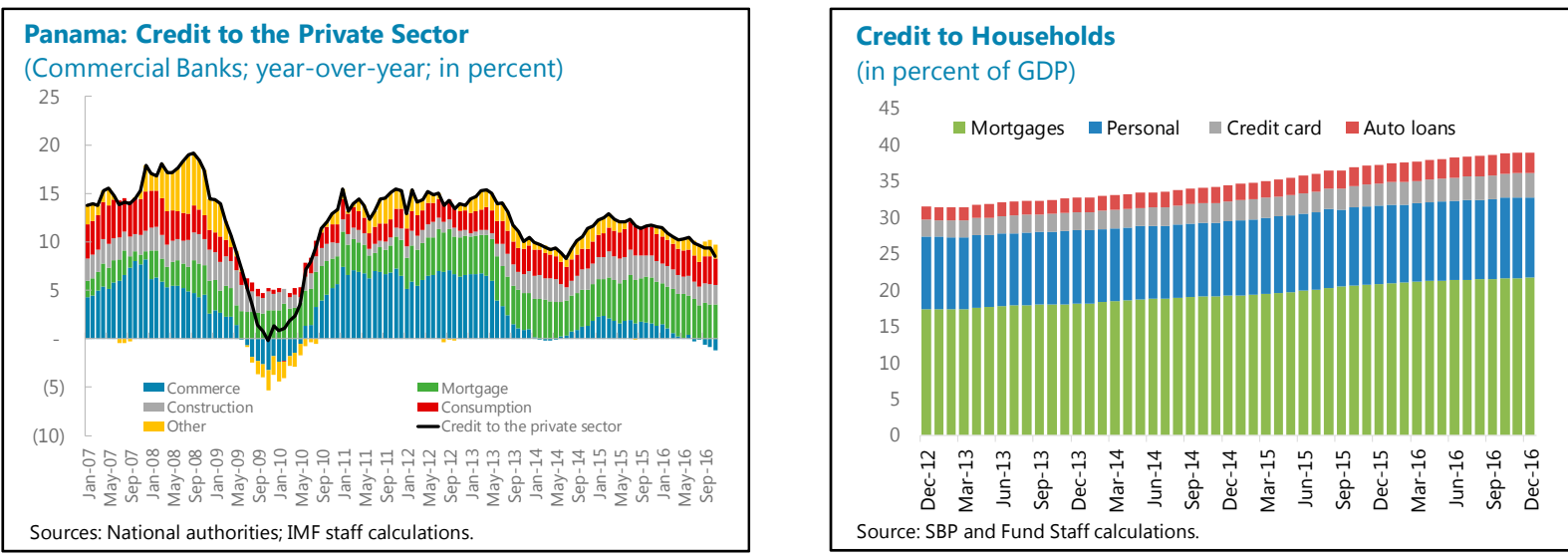

\section{A Framework for Systemic Risk Oversight and Macroprudential Policy in Panama: Building on Panama's Existing Framework}

\section{An effective framework for systemic risk oversight and macroprudential framework is}

multifaceted. First, an institutional environment needs to be put in place that will provide a supporting framework from which to assess overall risks to financial stability. Second, a framework for systemic risk oversight, guided by sufficient data, is important to effectively assess existing and emerging risks to financial stability. Finally, a framework for macroprudential policy, embedded in the institutional framework and guided by the systemic risk analysis, can be developed. This section assesses each of these components of Panama's existing framework and provides recommendations to strengthen these elements in support of Panama's ongoing efforts to promote financial stability. 


\section{Institutional Arrangement}

\section{A supportive institutional framework is needed to ensure adequate monitoring of systemic risks and enhance the effectiveness of macroprudential policy. Strong}

macroprudential policy frameworks are typically characterized with clear mandates that encourage a willingness to act by underpinning the legitimacy of policy action to address systemic risks. At the same time, adequate access to information and an effective surveillance capacity, supported by an appropriate set of macroprudential policy instruments, are needed to foster an ability to respond to systemic risks. Particularly in a decentralized supervisory structure, the institutional framework for macroprudential policy also needs to promote effective cooperation across institutions (IMF 2014).

\section{The FCC provides a sound starting point for Panama to strengthen its existing framework} for systemic risk analysis and macroprudential policy. Internationally, two models for macroprudential policy, differentiated primarily by the institution or committee to which the mandate is assigned, have prevailed. The first model assigns the macroprudential policy mandate to the central bank, while the second assigns it to a committee outside of the central bank, with the central bank participating on the macroprudential committee. ${ }^{6}$ With no central bank and an existing committee, the FCC, responsible for coordination of financial sector supervision and regulation in the decentralized supervisory environment, the second model is more relevant for Panama. ${ }^{7}$ Given the importance of the banking sector, the SBP will also need to continue to take a leadership role in systemic risk analysis and macroprudential policy, including through its role as chair of the FCC.

\section{The FCC should be given a clear financial stability mandate and be given formal} responsibility for macroprudential policy. In its existing state, the FCC does not have a formal role in systemic risk oversight or macroprudential policy. The FCC has a general objective "to recommend any other action that, in the best interests of the national financial sector, requires the exchange of information or coordination among financial supervisory entities", along with coordination on regulation, licensing and other issues. This objective should facilitate coordination and information exchange. However, existing coordination has focused on microprudential supervision at the institution or group-level (i.e. for financial conglomerates), rather than on systemic oversight. Vesting the FCC with a clear mandate and responsibility can help to strengthen systemic risk oversight by assigning clear responsibility and foster the willingness to act by holding the committee responsible for maintaining overall financial stability. To enhance accountability the objective related to systemic risk oversight could be specified in law. With the SBP maintaining a leadership role in the assessment of systemic risk and implementation of macroprudential policy,

\footnotetext{
${ }^{6}$ See also IMF (2011), Nier and others (2011) and IMF (2013) and IMF (2013b). IMF (2014) suggests that three models have prevailed as it differentiates between two types of models with the central bank being assigned the macroprudential policy mandate. In one model, the mandate is assigned to the central bank and in the other it is assigned to a dedicated committee within the central bank structure. We consider these models jointly.

${ }^{7}$ IMF (2013b) also evaluates the appropriateness of various institutional models of macroprudential policy for Panama and recommends that the FCC be given a clear financial stability mandate and be given responsibility for macroprudential policy.
} 
consideration could also be given to vesting the SBP with an explicit financial stability mandate and power to conduct macroprudential policy.

\section{Ongoing efforts to strengthen coordination through the FCC can facilitate its} transition to Panama's macroprudential authority. The SBP, the SMV and the SSRP have started to enhance cooperation through the FCC for oversight of financial conglomerates to effectively monitor group-wide activities and risks arising from these entities. As a basis for conglomerate supervision, some of the regulatory requirements for banks, including prudential requirements as well as corporate governance and risk management, have been enhanced to cover holding companies within their scope. Moreover, for the first time, the SBP, the SMV and the SSRP in 2017 will undertake joint inspections of financial conglomerates. Memoranda of Understanding (MOUs) are also in the process of being finalized to further strengthen information exchange. These are welcome steps from a microprudential standpoint, and could also be effective in addressing systemic risks since the effects of macroprudential tools targeting banks are partly extended to the non-bank sectors through conglomerate supervision. This enhanced cooperation on microprudential supervision can facilitate a transition toward stronger cooperation on oversight of systemic risks and macroprudential policy.

\section{Over the medium-term, it may be useful to move toward an integrated supervisory} model. Given the importance of financial conglomerates, coordination amongst supervisory authorities is imperative under the existing decentralized supervisory structure. Integration of supervisory responsibilities into a single organization could be an extension to existing efforts to strengthen coordination and may lower the cost of information exchange and coordination in regulatory and supervisory actions. ${ }^{8}$ The overall benefits and costs, as well as operational considerations, of the existing decentralized model should be compared to a more integrated model. In the event a more integrated supervisory model is pursued, the responsibility for systemic oversight and macroprudential policy should be vested with the new authority.

\section{Systemic Risk Oversight}

\section{Macroprudential policy needs to be supported with adequate oversight of systemic} risks. Systemic risk is "the risk of widespread disruption to the provision of financial services that is caused by an impairment of all or parts of the financial system and which can cause serious negative consequences for the real economy" (IMF/BIS/FSB 2009). As the objective of macroprudential policy is to limit systemic risk this cannot be accomplished without an understanding of the systemic risks facing an economy. Systemic risk is a multidimensional concept. Conceptually, systemic risk could be classified into two broad dimensions: the "time-dimension", which refers to the build-up of systemic risk over time, while the "structural dimension" associated with interconnectedness and contagious effects in the financial system. Along the time dimension, systemic risks can arise from economywide vulnerabilities from excessive growth in total credit or assets prices, but may also arise from vulnerabilities specific to particular sectors like households and corporates such as growing credit to

\footnotetext{
${ }^{8}$ While it is not discussed in depth here, information exchange from AML/CFT, such as suspicious financial transactions, customers and their ultimate beneficial owners, is also important in this context.
} 
the household sector or increased exposures to the corporate sector. Systemic risks may also be related to liquidity including maturity mismatches or increased reliance of banks on non-core funding, or structural in nature, due to interconnections between and within classes of financial intermediaries, across borders or from market infrastructure for example.

18. Systemic risk monitoring is at nascent stage of development in Panama. With no single institution responsible for systemic risk oversight, the responsibility has, in practice, fallen primarily to the SBP given the importance of the banking sector. The SBP has made significant progress to strengthen systemic risk oversight. It publishes an annual financial stability report in which it summarizes its assessment of risks at the overall, sectoral, liquidity and structural levels. A multifaceted approach, including monitoring developments in credit and assets prices and conducting stress tests of the resiliency of the banking sector to macroeconomic and financial shocks is used to assess overall risks. ${ }^{9}$ Data gaps continue to hinder adequate monitoring of sectoral risks, particularly related to households, however, efforts are underway to develop new data on household income and indebtedness as well as property prices. The SBP has also begun to monitor structural risks to financial stability by developing a methodology to identify systemically important banks based on the Basel Committee's methodology, and plans to begin network analysis of banks' interconnections. ${ }^{10}$ The financial stability report also includes basic information on the non-bank segments of the financial sector, such as the number of entities, size of assets, and operational results. However, a more detailed assessment of overall risks requires cooperation of all supervisors.

\section{The FCC could play an important role to further strengthen the assessment of systemic}

risks. Further strengthening the assessment of systemic risks facing the Panamanian financial sector requires enhanced cooperation of other supervisory agencies. Such cooperation will be critical to assess structural risks from interconnections across classes of financial intermediaries and to monitor systemically relevant developments in non-bank sectors. For the latter, primary areas of focus could include, household credits provided by non-bank deposit takers (e.g. credit cooperatives), and developments in capital-market instruments (e.g. asset managers) especially where they entail maturity and/or risk transformations. Vested with an explicit mandate for systemic risk oversight and macroprudential policy, the FCC would be the appropriate venue to cooperate on the assessment of systemic risk. Discussion and analysis of systemic risk should be a standing agenda item for FCC meetings along with regular information exchange between authorities, as an extension of ongoing coordination across supervisors.

\footnotetext{
${ }^{9}$ Stress tests consider the impact of both macroeconomic and interest rate shocks to the banking sector (for baseline, moderate stress and severe stress scenarios) through their impact on nonperforming loans and bank capital adequacy. An early warning indicator system is also in place to monitor credit risks. Financial stability maps and a financial stability index are also used to inform the assessment of overall risks to financial stability.

10 Panama is also participating in a regional initiative, coordinated through the Central American Council of Superintendents of Banks, Insurers, and other Financial Institutions (CCSBSO), to strengthen the monitoring of systemic risks to regional financial stability.
}

(Continued) 
20. The capacity for systemic risk oversight needs to be strengthened. Within the SBP there is a distinct unit (the Financial Studies Division), responsible for systemic risk oversight, however the unit is relatively small and would benefit from increased resources to fulfill its function. Enhancing risk-based supervision could be an important precursor for the non-bank sector to begin systemic risk oversight as the SMV and the SSRP remain in the early stages of transiting to risk-based supervision. ${ }^{11}$

21. Adequate data is needed to support systemic risk oversight. Table 3 provides a list of signals that could be used to strengthen the assessment of systemic risk and the relevance of macroprudential policy measures and indicates which of these signals are currently being monitored by the SBP for the banking sector. With the build-up of household credit presenting the most pressing financial stability risk, the priority should be to continue efforts to collect and analyze data on real estate prices, loan write-offs, LTVs, and leverage indicators for households and corporates and to continue to build capacity to analyze macro-financial linkages. Ongoing efforts to strengthen mechanisms for information exchange across supervisors will also need to continue to ensure that existing data gaps on the interconnections across segments of the financial system are filled to provide a complete overview of safety and soundness in the financial system.

\footnotetext{
${ }^{11}$ The SMV have received series of TA on risk-based supervision starting from 2014. The SSRP is also receiving support from outside consultancy.
} 


\section{Macroprudential Policy Tools}

22. Appropriate macroprudential tools should be employed to different types of systemic risk that are relevant in Panama. Macroprudential policy tools are defined as "the use of primarily prudential tools to limit systemic risk". ${ }^{12}$ Different policy tools need to be applied to address different categories of systemic risks. Systemic risks from general credit boom and bust cycle should be addressed by broad-based capital tools such as capital buffers and leverage ratio requirements, while the risks in household or corporate sectors necessitate more targeted tools such as sector specific capital requirements and caps on LTV, DTI or DSTI ratios. Resilience against liquidity stress could be ensured by requiring enough liquid asset buffers and restrictions on funding structure or maturity mismatch. Lastly, the structural vulnerability from systemically important financial institutions (SIFIs) can be addressed by targeted prudential requirements, supervisory framework and enhanced resolvability, while other tools including large exposure limits and risk-weighting could also mitigate such risk. This section analyses the Panama's current prudential policy framework with respect to each of these areas, and discuss recommended actions.

\section{Broad-Based Macroprudential Policy Tools}

\section{The financial system needs to build enough capital buffers in stable periods to absorb} losses in downturns and avoid procyclical lending. Broad-based macroprudential policy tools are designed to build these capital buffers and can include countercyclical capital buffers (CCBs), dynamic loan loss provisioning requirements (DPRs), leverage ratios, and caps on credit growth. These tools are complementary and aim to enhance the resilience of the financial sector, with a focus on the banking sector, and to reduce the procyclicality of bank lending. Capital buffers are designed to cover unexpected losses that occur in times of financial stress, by providing an additional buffer to be drawn on. Basel III has introduced two types of capital buffers: the capital conservation buffer is fixed at 2.5 percent in common equity Tier 1 (CET1), while the level of CCB is raised when boom in credit cycle is observed and lowered in the bust phase (that is, in a countercyclical manner) within the range of 0 and 2.5 percent. ${ }^{13}$ Dynamic provisioning (DPR) is complementary to the $C C B$, it requires loan-loss provisioning to cover expected losses (EL) over an average economic cycle. Provisioning based on DPR is thus more countercyclical compared with provisioning based on incurred losses. While there are several variations in specifications, DPRs typically allow banks to build a countercyclical reserve in boom periods and draw it down in downturn to cover losses. ${ }^{14}$ Lastly, the leverage ratio, which is also an element of Basel III, complements the risk-based capital requirements by containing the build-up of systemic risk through excessive leverage of financial institutions in a boom period. Finally, caps on credit-growth have been used by some countries to reduce excessive credit growth.

\footnotetext{
12 IMF-FSB-BIS (2016).

13 See BCBS (2010) for Basel III framework. While these capital buffers are not considered "regulatory minimum", a bank needs to restrict payout of its earning (hence conserving its capital) where there is a breach of required buffer level.

${ }^{14}$ See Wezel, Chan-Lau and Columba (2011) for detailed discussion of the framework.
} 


\section{Panama has been focused on strengthening microprudential regulation to build appropriate capital buffers, which is an important precursor to macroprudential policy. The focus has primarily been on implementing Basel III capital and liquidity requirements:}

- Capital: The SBP revised its definition of regulatory capital in 2015 to align it with Basel III, introducing the minimum of 4.5 percent for CET1, 6 percent for Tier 1 (T1) and 8 percent for the total risk-based capital. ${ }^{15}$ Risk-weights for credit risk were revised in March 2016 to incorporate elements of Basel II, which have been implemented from July 2016. ${ }^{16}$ The scope of these requirements was also extended to bank holding companies, an important step to strengthen consolidated supervision. Basel III consistent capital charges for operational and market risk are expected to be implemented in 2017. Broadening the coverage to these important risk categories, while also strengthening monitoring and requirements for risk management, would further enhance resilience of the sector. ${ }^{17}$

- Leverage ratio: A minimum requirement for leverage ratio was introduced together with the new definition of capital in 2015 and application started from the third quarter of 2016. The ratio is defined as CET1 capital over total non-risk-weighted exposures, with a minimum requirement of 3 percent. While aggregate statistics of the leverage ratio is not yet available, Panamanian banks' RWA density (RWA divided by total non-risk-weighted credit exposure) around 70 percent, suggesting that banks are much less leveraged than the maximum allowed by leverage ratio regulation. ${ }^{18}$ Nevertheless, the monitoring of the ratio and its historical trend would give an insight on development of systemic risk.

\section{As a complement to the strengthening of microprudential regulation, Panama also} introduced DPR. The SBP introduced DPR in 2013, with application starting from 2014, as part of a rule for broader credit risk management and provisioning. ${ }^{19}$ In this system, the level of DPR for each bank is calculated every quarter based on loan outstanding (RWA-based) and the quarterly change in the amount of risk-weighted loan exposures, and quarterly variation in specific provisions. ${ }^{20}$ It is a

\footnotetext{
${ }^{15}$ Regulation No.001-2015. The definitions of capital are consistent with Basel III except for technical features such as loss absorbency at the non-viability of Additional Tier 1 (AT1) and Tier 2 (T2), and the automatic write-down or conversion of AT1. The strengthened minimum capital requirements are being phased-in, starting from 3.75 percent for CET1 and 5.25 percent for T1, and through January 2019.

${ }^{16}$ Regulation No.003-2016.

${ }^{17}$ For instance, investment in securities consist around $15 \%$ of the balance sheet of the banking system. While there is no breakdown for purposes of securities holding at the system level, some of the largest banks classify majority of their holding as available-for-sale securities. Even if the size of pure trading operation is relatively small, the interest rate risk in the banking book would be an important risk factor. As for operational risk, compliance issue including AML/CFT could pose certain legal or reputational risks for banks (the latter is not included in the definition of operational risk by the Basel Committee of Banking Supervision (BCBS), it could be important in Panama's context).

18 Based on the assumption that the banks' capital base mostly consists of CET1.

19 Regulation No. 004-2013.

20 The amount of DPR in the period $t$ is defined as $D P R(t)=\alpha L(t)+\beta \max \{\Delta L(t), 0\}-S P(t)$, where
} 
capital account item that is disclosed as a stand-alone item and banks are required to maintain the amount of DPR in addition to the 8 percent regulatory minimum capital requirement. This specification resembles the "through-the-cycle accumulation systems" in Wezel et al. (2012), but has some features that are not present the original concept of DPR. For one thing, the draw-down in the downturn phase is restricted and subject to SBP's decision ${ }^{21}$ and use of RWA is not a common feature of DPR. Considering these specifications, the Panamanian version of DPR seems to bear some similarities with capital buffers, in addition to the role as loan-loss provisioning. It remains to be seen if the DPR will be work in a countercyclical manner in downturn periods, with its effectiveness subject to the SBP ability to determine the appropriate commencement of the drawdown phase.

\section{Additional capital buffers could be considered to further strengthen resilience of the financial system, but would need to be designed in consideration with existing DPRs. The} presence of several financial conglomerates and systemically important banks in Panama reinforces the need to have strong capital buffers. The capital adequacy ratio of the national banking system has been hovering around 15 percent even under the updated capital definition, which effectively means banks on average would be able to absorb additional capital requirements. ${ }^{22}$ To further enhance the resilience of the system, capital conservation and/or counter-cyclical buffers could be introduced when the new minimum capital requirements are fully implemented in 2019. The SBPs recent development of a methodology to identify SIFIs could be the first step toward strengthening resiliency of the system to SIFIs and is an important first step toward consideration of additional capital buffers for these institutions. Given the similarity of the existing DPRs in Panama to capital buffers, the design of additional capital buffers, whether capital conservation of counter-cyclical, would need to consider existing DPRs.

\section{Sector Specific Macroprudential Policy Tools}

27. There are several policy options to address the pro-cyclical build-up of risks in specific sectors, usually the household or corporate sector. One of these tools is sectoral capital requirements, either in the form of higher risk weights to exposures to or additional capital requirements on specific economic sectors. ${ }^{23}$ Increases in the required amount of regulatory capital, would suppress credit provision to the sectors by raising the cost of capital, while also increasing the resilience of the lenders by requiring additional buffers against negative shocks stemming from

\footnotetext{
$\alpha=1.50 \%, \beta=5.00 \%, L(t)=$ risk-weighted assets (RWA) for loans classified under the normal category, $S P(t)=$ variation in the balance of specific reserves. The amount of DPR is capped at $2.5 \%$ of qualifying RWA, and is subject to the floor of $1.25 \%$ of qualifying RWA. Assuming the second and the third terms are relatively small compared with the first term, this system of DPR could tend to float around $1.50 \%$.

${ }^{21}$ The Article 37 of Regulation No. 004-2013 stipulates that the amount of DPR "cannot be less than the amount established in the previous quarter, unless the decrease is the result of a conversion to specific provisions", and the SBP "will establish the criteria for the above conversion.

${ }^{22}$ It should be noted that introduction of capital charges for market risk and operational risks could have negative impact on regulatory capital adequacy ratio.

23 Sectoral requirements can also be imposed on a segment of household or corporate borrowing.
} 
those sectors. Another approach is to put quantitative caps on new credit provisions using measures on borrowers' creditworthiness, such as loan-to value (LTV) ratio, debt-to-income (DTI) ratio or debt-service-income ratio (DSTI) in the case of household sector. Each of these tools directly restrict credit supply to excessively leveraged or indebted borrowers, while also enhancing financial resilience by lowering the probability of default (PD) or loss given default (LGD) by restricting highrisk credits. Tools targeting corporate sectors are conceptually the same, typically using LTVs and debt-service coverage (DSC) ratios as metrics.

\section{The SBP has recently put in place sectoral risk-weights targeted at the household}

sector. While these risk-weights were primarily put in place as part of the ongoing strengthening of microprudential regulation, they could also be used as a macroprudential policy tool. The riskweights introduced in March 2016 became effective in July 2016 and broadly align the treatment of household exposures in regulatory capital requirements with Basel II. ${ }^{24}$ Risk weights are 35 percent or 50 percent for qualifying residential mortgage exposures with lower LTV ratios and more recent appraisals, and 100 percent risk weight is applied to others. ${ }^{25}$ The baseline risk weight for personal loans is 100 percent if the term is less than five years and there is no collateral or any other credit risk mitigatory available. ${ }^{26}$ With banks on average currently operating well above the regulatory minimum capital requirements, the introduction of these sectoral risk weights and resulting overall tightening of risk-weights may not affect banks' credit underwriting decisions and capital planning. In this context, it is not clear if these risk-weights could be effectively calibrated as a macroprudential tool to actively address the accumulation of sectoral risks and other targeted sectoral measures may be more effective.

\section{The use of macroprudential policy tools targeted toward the household sector, particularly risks related to real estate is appropriate. The rapid growth of consumer and} residential mortgage exposures in the recent years, as well as property prices, presents the most immediate macro-financial risk to the Panamanian economy. In this context, the existing sectoral risk weights could be complemented with additional measures that may, in the Panamanian context, better target the build-up of these risks such as a cap on LTV ratios and caps of DTI or DSTI ratios.

\section{LTV-based macroprudential policy tools could help to mitigate the build-up of} systemic risks from residential mortgages in Panama. Restrictions on LTV ratios for the underwriting of new credit, mostly residential mortgage exposures, directly limit or prohibit credit flows to high-risk counterparties, and hence could reduce credit provision as well as housing demand (credit demand channel). Restricting high-risk exposures also means lower PD or LGD on

\footnotetext{
${ }^{24}$ See BCBS (2006) for details of treatments in Basel II.

25 35\% risk-weight is available for mortgage for primary home if the LTV (based on the lowest value in the appraisal report) is less $80 \%$ and the appraisal value is less than three years old. The outstanding of qualifying exposures in the national banking system is about $\$ 2.7$ billion, which is slightly about $20 \%$ of the local residential mortgage exposures. This relatively low share could be because of existence of exposures that are related to secondary homes or do not satisfy other criteria such as periods after the last appraisal, even though some of them might have LTV less than $80 \%$.

${ }^{26}$ Basel II allows 75\% risk-weight for retail exposures satisfying certain criteria, which is not implemented in Panama.
} 
borrowers' side, which effectively enhance the lenders' resilience (resilience channel). Lower LTV also means increased down payment, which reduces borrowers' incentive to default (anti-default channel). Lastly, the introduction of such regulation lowers the expectation on future housing prices, and hence lowers speculative incentives of the borrowers (expectation channel). As part of their risk management practices, Panamanian banks are already monitoring LTV ratios and many report the ratio and its distribution in annual and quarterly financial disclosure documents, suggesting that implementation of an LTV cap would be feasible for the sector. However, an important challenge will be to determine the appropriate calibration of the cap. While some of the large banks report that most their residential mortgage exposures have relatively low LTVs of under 80 percent and LTV is referenced in the capital adequacy regulations, there are no consolidated statistics available on existing LTV ratios and practices. Another consideration in the design of the overall effort to target the build-up of risks the real-estate sector is that it anecdotal evidence suggests that property prices are rising in Panama. In this environment, an LTV cap can become less binding over time, reducing its effectiveness.

\section{Implementation of an LTV cap could be tailored to the structure of the Panamanian} mortgage market. The simplest way to implement these policy tools is to put a single cap on all relevant exposures, such as a flat 80 percent cap on the LTV ratio, but they could be implemented in a more tailored and nuanced manner. For instance, the residential mortgage market in Panama is diverse and anecdotal evidence suggest that demand for the high-end market is slowing, while the mid-to-low income market still shows robust growth. The segment of under $\$ 120,000$ are eligible for the government's interest rate subsidies, which works to limit credit risk even for high LTV loans. The sectoral macroprudential tools could consider these characteristics to specifically target the most important segment in terms of systemic risk, while also minimizing the distortive effects.

32. A DTI or DSTI limit could complement an LTV cap. The channels through which the effect of DTI or DSTI limit is transmitted are similar to the LTV cap. However, household incomes tend to fluctuate less over the credit or economic cycle than property prices, making these indicators more stable. With property prices rising in Panama, these measures could potentially be more binding than an LTV cap at the current stage of the economic cycle and an important complement over the medium-term. In addition, the scope of a DTI or DSTI limit could be broader than an LTV cap limited to collateralized exposures and help to address the broader build-up of risks to the household sector from rapid growth in personal loans. Since DTI or DSTI are not defined or referenced in the current monitoring and regulatory framework, it is imperative to accumulate reliable data on the level and distribution of these ratios for effective implementation. On the other hand, the industry has been practicing automatic payroll deduction for repayment of household sector credit, which effectively limited DSTI to 50\%, and the regulatory and monitoring framework could build on it. 
Figure 2: Transmission Mechanism of Selected Sectoral Macroprudential Instruments

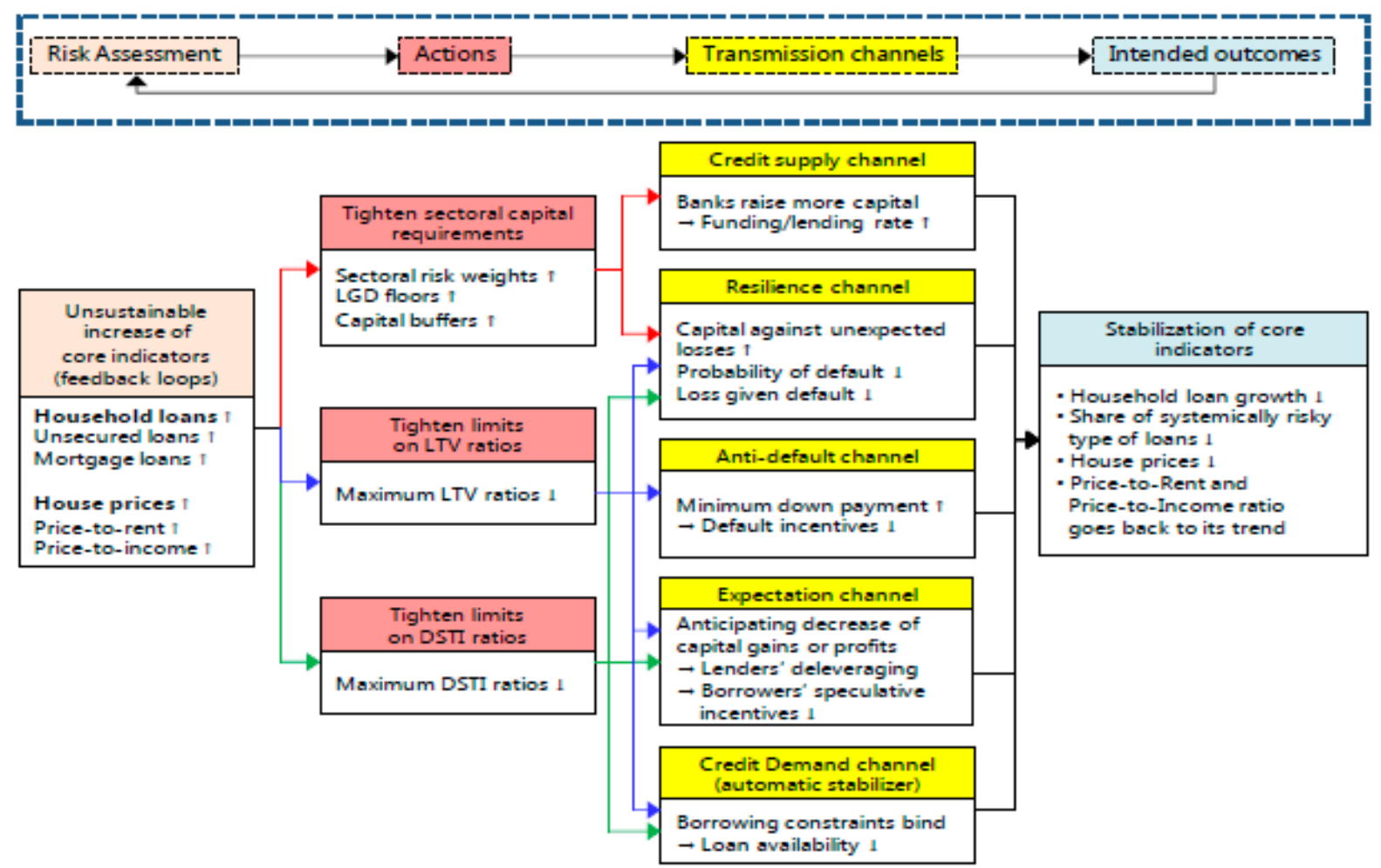

Source: IMF (2014).

\section{Liquidity tools}

\section{Liquidity tools aim to ensure the resilience of the financial system against systemic} liquidity shocks, while also mitigating structural vulnerabilities such as excessive maturity mismatches. Examples include tools developed by Basel Committee of Banking Supervision (BCBS), such as the liquidity coverage ratio which is defined as the ratio of high quality liquid asset over assumed cash outflow in 30 days of severe liquidity stress. ${ }^{27}$ The Net Stable Funding Ratio (NSFR) aims to act on banks' funding structure by requiring the amount of stable funding that matches holding of long-term assets. While these BCBS tools are mainly for internationally active banks, simpler measures with the same concepts could also have a similar policy effect. In Panama's context, the liquid asset buffer is the most important given the lack of central bank and deposit insurance.

34. Current regulations on liquidity buffers could be enhanced. The existing quantitative liquidity regulation is on the legal liquidity index (LLI), defined as the ratio of liquid assets as a share of qualifying deposits. While the ratio has been hovering around 60 percent on average against the minimum of 30 percent, it is inadequate both as a regulatory and monitoring tool. For instance, the

${ }^{27}$ BCBS 2013a. 
range of eligible liquid asset buffer is relatively broad and liquidity risks from non-traditional funding such as short-term inter-bank transactions are not considered, although they are relatively small in Panama as of now. ${ }^{28}$ The breakdown of the LLI is also used as the primary monitoring indicator for liquidity, but its long assumed horizon of 186 days make it less plausible as a monitoring tool.

35. The planned introduction of the LCR is an important step to strengthening liquidity at the institution-specific and systemic level. While similar conceptually to the LLI, the LCR covers a shorter time horizon of 30 days and the definition of High Quality Liquid Assets (HQLA) is narrower and more conservative. The scenario on cash outflow is calibrated based on the severe liquidity stress around September in 2008 and has comprehensive coverage regarding cash outflows. In fact, Komaromi, Hadzi-Vaskov and Wezel (2016) suggested that many banks could face liquidity shortage if LCR definition is applied. The SBP is expected to finalize the design of its LCR in 2017 for implementation beginning in 2018, which would be an important step to enhance resilience of banks against adverse liquidity shocks.

\section{Structural tools}

\section{Structural macroprudential policy tools are designed to mitigate systemic risks which} arising from interconnections within the financial sector and related spillover effects. The failure of SIFIs, for example, could pose negative externalities to the financial sector and broader economy, due to their size, interconnectedness within the financial system and lack of substitutability. The policy tools identified by the Financial Stability Board (FSB) and BCBS for SIFIs include additional loss absorbency in the form of capital buffers, intensive supervision and improved resolvability. In addition, prudential tools such as limits on large exposures could put disincentives on interbank transactions and thus mitigate excessive interconnectedness within the financial sector.

\section{SBP has started designating systemically important banks (SIBs), but no policy} measures have been implemented. The SBP has already identified a non-public list of SIBs based on indicators such as size, interconnectedness, cross-jurisdictional activities, complexity and substitutability. The SBP also considers cross-jurisdictional activities as country specific factors in its SIBs identification methodology, which is appropriate considering the importance of regionally active financial conglomerates. ${ }^{29}$ As for policy options to address risks from these institutions, a flat or bucketed capital surcharge is a possible options. In addition, monitoring of SIBs is currently not distinguished from other banks except as a part of general risk-based supervision, and a more intensive framework could be explicitly developed in the future.

\footnotetext{
28 There are some restrictions or haircuts based on the ratings of the issuers. In addition, the loan inflows within $186-$ day horizon could be included as liquid assets up to $50 \%$.

${ }^{29}$ It is an element for the methodology for Global SIBs, but not included for Domestic-SIBs. See BCBS 2012 and BCBS 2013b for each methodology.
}

(Continued) 
38. The desirability of other policy measures to address interconnectedness should be assessed based on further analysis. To limit the concentration risk which could arise from failure of single counterparty, SBP limits the amount of an exposure to single counterparty (measured at group level) to $25 \%$ of $\mathrm{T} 1$ capital, in a manner which is broad in line with BCBS standard. ${ }^{30}$ While interbank transactions in Panama may not be as important as in advanced economies, there exist sizable interbank deposits. Banks maintain clearing account in the Banco Nacional de Panama (BNP), a state-owned bank, which is mandated by Law to provide clearing and settlements to other banks, making the BNP an important player in the interbank network. ${ }^{31}$ The necessity of further policy tools should be assessed based on further analysis of interconnectedness within the financial market (see paragraph 18).

\section{E. Crisis Management Framework}

39. In general, an effective financial safety net to address systemic risks consists of supervisory power with early intervention, a resolution framework, an independent central bank with able to provide emergency liquidity assistance (ELA), and deposit insurance.

Supervisors need to identify vulnerabilities in financial institutions early enough so that they can take corrective actions to minimize the negative consequences for the financial system. The resolution framework for the financial sector should be able to resolve financial institutions without causing severe systemic disruption, as occurred during the global financial crisis. When a systemwide liquidity stress is present, discretionary emergency liquidity provision by the central bank might be necessary, while putting in place proper arrangements to mitigate any side effects including moral hazard. A deposit insurance scheme to protect certain amount of deposits could prevent bank runs and contagion to other financial institutions, again with appropriate governance and structure to mitigate moral hazard.

40. While the SBP has a strong track record of early intervention and orderly resolution of small banks, an upgrade of the resolution framework is desirable. The special resolution scheme for banks outside of regular corporate bankruptcy procedure is stipulated in the Banking Law, in which the SBP is considered as the single resolution authority. The scheme consists of three processes: temporary operational control of a bank by the SBP, reorganization of a bank through administrator, and compulsory liquidation. The SBP has resolved several small banks effectively without causing contagion, including the case of BUSA in 2015, which resulted in acquisition by another bank. ${ }^{32}$ However, the Fund's TA in 2016 found out that there are still some gaps in the framework, including reorganizer's lack of power regarding transfer of assets and liability of resolved entity, no rule on establishment of bridge institutions, and lack of power to override shareholders' rights. These weaknesses resulted in the delayed process some of the recent cases. ${ }^{33}$ The SBP is now

\footnotetext{
${ }^{30}$ BCBS 2014.

${ }^{31}$ Article 5, Law No. 4 of 2006.

32 The BUSA was one of the small banks with the asset size of US\$372 million as of May 2015.

33 For instance, the SBP intervened with the Balboa Bank \& Trust on May 5 in 2016, and the reorganization procedures have been extended multiple times.
} 
working to address these gaps with follow-up TA anticipated in 2017 to identify the road map for revision of the framework.

\section{With no central bank, Panama lacks a lender of last resort (LOLR) and other supportive} liquidity mechanisms have yet to be put in place. The Banco Nacional de Panama introduced a $\$ 500$ million repo facility for local banks in 2016 . The structure is a relatively straightforward repo transaction, accepting certain classes of local government and corporate bonds, subject to haircuts, and offering LIBOR plus 200 basis points. While the facility is welcome and could be used by banks to deal with idiosyncratic liquidity shocks, it is not necessarily restricted for LOLR purpose, and some banks have already utilized it for standard repo transactions. The coverage of $\$ 500$ million is also insufficient for systemic liquidity shocks at less than one percent of the total deposits in the banking system. Importantly, the facility is not separated from the other regular operations of BNP, which could raise a concern for potential conflict of interests when seen as a tool for LOLR. Given these drawbacks, there remains the need to establish a liquidity facility with adequate resources to address systemic shocks with an independent structure.

42. The Panamanian authorities have not yet introduced deposit insurance. Historically, banks have preferred to self-insure against banks runs, rather than to contribute to funding for a public deposit insurance scheme. The only existing depositor protection mechanism is the priority on the repayment up to US\$10,000 given in the process of liquidation. The costs and benefits of deposit insurance should be examined along with the upgrade of bank the resolution regime, considering the international best practices. ${ }^{34}$

43. Crisis management plans should to be created through the FCC. Given the lack of certain elements of an effective financial safety net, the relevant authorities (especially the SBP and the Ministry of Economy and Finance) need to enhance their crisis preparedness. A crisis management plan should be elaborated to coordinate the response of supervisory agencies. The FCC should be tasked with preparing such a plan, including through undertaking hypothetical simulation exercises.

\section{F. Conclusions}

44. As a regional financial center, Panama should improve its framework for systemic risk oversight, despite recent positive progress. Given the decentralized supervisory structure with no central bank, and given the backdrop of strong credit growth in recent years, Panama needs to ensure powers, responsibilities and capacities to effectively monitor the entire financial sector and make appropriate decisions regarding macroprudential policy. The FCC is an appropriate coordination body for supervisors and has strengthened its coordination on microprudential supervision of conglomerates, but it could be given an explicit mandate for systemic risk oversight and macroprudential policy, with the SBP continuing to play a leading role as chair of the FCC. The SBP has made significant progress to strengthen monitoring of systemic risk in banking sector, but it

\footnotetext{
${ }^{34}$ International Association of Deposit Insurers (2014)
} 
is still at nascent stage and data collection, organizational capacity and coordination with other bodies through the FCC could be further improved.

45. Tailored macroprudential policy tools should be developed in Panama, The SBP has already implemented Basel III based capital regulations as a basis for broad-based capital tools, and additional capital buffers could be considered while considering existing DPR. Systemic risks from the household sector are among the most important in Panama's context, and a combination of LTV and DSTI could be effective to mitigate these risks. Full implementation of LCR is expected to ensure resilience of banking sector against systemic liquidity stresses, which is especially important given the lack of ELA and deposit insurance. The identification of SIFIs is a welcome step to address structural risk in the financial system, and it is recommended to develop regulatory/supervisory tools targeted to them.

46. Panama needs to address gaps in crisis management framework. While the SBP has intervened early and dealt with failure of small banks in the past, an update of the bank resolution framework could ensure orderly resolution even in cases of systemic failures. On the other hand, Panama still lacks appropriate ELA despite the recent introduction of repo facility by BNP, and creation of a liquidity facility to deal with systemic liquidity shock is desirable. Introduction of deposit insurance in line with the international standard would further enhance Panama's crisis management framework. Lastly, the crisis management plan to coordinate response of authorities could be created, with facilitation through the FCC. 


\section{References}

Basel Committee on Banking Supervision, 2006, "International Convergence of Capital Measurement and Capital Standards", June 2006

Basel Committee on Banking Supervision, 2010, "Basel III: A global regulatory framework for more resilient banks and banking systems", December 2010

Basel Committee on Banking Supervision, 2012, "A Framework for Dealing with Domestic Systemically Important Banks", October 2012

Basel Committee on Banking Supervision, 2013a, "Basel III: The Liquidity Coverage Ratio and liquidity risk monitoring tools", January 2013

Basel Committee on Banking Supervision, 2013b, "Global Systemically Important Banks: Updated Assessment Methodology and the Higher Loss Absorbency Requirement", July 2013

Basel Committee on Banking Supervision, 2014, "Supervisory Framework for Measuring and Controlling Large Exposures", April 2014

International Association of Deposit Insurers, 2014, "IADI Core Principles for Effective Deposit Insurance Systems", November 2014

International Monetary Fund, 2011, "Macroprudential Policy: An Organizing Framework," IMF Policy Paper, March (Washington: International Monetary Fund).

International Monetary Fund, 2013, "Key Aspects of Macroprudential Policy," IMF Policy Paper, June (Washington: International Monetary Fund).

International Monetary Fund, 2013b, "Panama: Selected Issues," International Monetary Fund Country Report No. 13/89. (Washington: International Monetary Fund).

International Monetary Fund, 2014, "Staff Guidance Note on Macroprudential Policy." (Washington: International Monetary Fund).

International Monetary Fund, 2014b, "Staff Guidance Note on Macroprudential Policy: Detailed Guidance on Instruments." (Washington: International Monetary Fund).

International Monetary Fund, Financial Stability Board, and Bank for International Settlements, 2009, "Guidance to Assess the Systemic Importance of Financial Institutions, Markets and Instruments; Initial Considerations."

International Monetary Fund, Financial Stability Board, and Bank for International Settlements, 2016, "Elements of Effective Macroprudential Policies: Lessons from International Experience." 
Komaromi, Andras, Metodij Hadzi-Vaskov, and Torsetn Wezel, 2016, "Assessing Liquidity Buffers in the Panamanian Banking Sector," International Monetary Fund Working Paper WP/16/200.

(Washington: International Monetary Fund).

Nier, Erlend W., Jacek Osiński, Luis I. Jácome, and Pamela Madrid, 2011, "Institutional Models for Macroprudential Policy," IMF Staff Discussion Note 11/18 and Working Paper 11/250 (Washington: International Monetary Fund).

Wezel, Torsten, Jorge A. Chan-Lau and Francesco Columba, 2012, "Dynamic Loan Loss Provisioning: Simulations on Effectiveness and Guide to Implementation," International Monetary Fund Working Paper WP/12/110. (Washington: International Monetary Fund). 